Journal of Medicinal Chemistry 2019; 62 (11): 5382-5403

DOI: $10.1021 /$ acs.jmedchem.9b00003

\title{
Potent 5-Cyano-6-Phenyl-Pyrimidin-Based Derivatives Targeting DCN1-UBE2M Interaction
}

\author{
Wenjuan Zhou ${ }^{\dagger, *, \#, ~ L i y i n g ~ M a ~}{ }^{\dagger, \#, ~ L i n a ~ D i n g ~}{ }^{\dagger}$, Qian Guo ${ }^{\dagger}$, Zhangxu He ${ }^{\dagger}$, Jing Yang \\ Hui Qiao ${ }^{\dagger}$ Lingyu Li ${ }^{\dagger}$, Jie Yang ${ }^{\dagger}$, Shimin Yù ${ }^{\dagger}$ Lili Zhao ${ }^{\dagger}$, Shaomeng Wang ${ }^{\dagger}$, \\ Hong-Min Liu ${ }^{\dagger, *}$, Zhenhe Suo ${ }^{*, *}$, Wen Zhao ${ }^{\dagger, *}$
}

†State Key Laboratory of Esophageal Cancer Prevention and Treatment; Key Laboratory of Advanced Pharmaceutical Technology, Ministry of Education of China; School of Pharmaceutical Sciences, Zhengzhou University, 100 Kexue Avenue, Zhengzhou, Henan, 450001, China

Department of Pathology, Oslo University Hospital; Faculty of Medicine, University of Oslo, Oslo, 0379, Norway

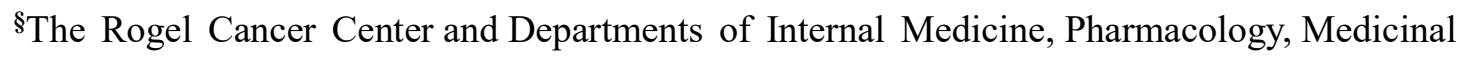
Chemistry and Pathology, University of Michigan Medical School, Ann Arbor, Michigan, 48109, United States

\#: Both authors contribute equally to this work.

*: These senior authors contribute equally to this work.

*: Corresponding to:

Wen Zhao, Email: zhaowen100@139.com, zhaowen@zzu.edu.cn; Phone, 86-15003898187

Zhenhe Suo, Email: zhenhe.suo@medisin.uio.no; Phone, 47-98280093

Hong-Min Liu, Email: liuhm@zzu.edu.cn; Phone, 86-371-67781739. 


\section{- ABSTRACT}

Neddylation of the Cullin-RING E3 ligases (CRLs) regulates the homeostasis of approximately $20 \%$ of cellular proteins. Defective in cullin neddylation 1 (DCN1), as a co-E3 ligase, interacts with UBE2M to enhance the activation of CRLs and this interaction is emerging as a therapeutic target for human diseases. Here, we present a series of pyrimidin-based small molecular inhibitors targeting DCN1-UBE2M interaction. After finding a novel inhibitor DC1 with $\mathrm{IC}_{50}=1.2 \mu \mathrm{M}$, we performed a series of chemical optimization, which finally led to the discovery of a potent thiazole contained 5-cyano-6-phenylpyrimidin-based inhibitor DC-2 $\left(\mathrm{IC}_{50}=15 \mathrm{nM}\right)$. Next, using protein and cellular thermal shift assays, co-immunoprecipitation, molecular docking and site specific mutation experiments, we further proved that DC-2 specifically inhibited the interaction of UBE2M and DCN1 at molecule and cellular levels, resulting in the decrease of cullin3 neddylation and accumulation of its substrate: NRF2. Our findings indicate that DC-2 may serve as a novel lead compound for specific derivatives targeting DCN1-UBE2M interaction. 


\section{- INTRODUCTION}

The ubiquitin-proteasome system (UPS) is integral to maintaining cellular protein homeostasis by regulating degradation of intracellular proteins. ${ }^{1-7}$ The ubiquitylation pathway is executed by the coordinated efforts of the E1 (ubiquitin-activating enzyme), E2 (ubiquitinconjugating enzyme) and E3 (ubiquitin ligase enzyme) proteins. ${ }^{5}$ Like ubiquitination, ${ }^{8}$ neddylation is a novel type of posttranslational modification, in which the ubiquitin-like molecule NEDD8 is added to its target proteins and thus regulates their functions. ${ }^{9}, 10$ Neddylation also consists of a tripartite enzymatic cascade, including the NEDD8-activating enzyme E1 (NAE, APPBP1 (NAE1) and UBA3 heterodimer), two NEDD8-conjugating enzymes E2s (UBE2F and UBE2M, also known as UBC12) and NEDD8-E3 ligases, ${ }^{9,}{ }^{10}$ with cullins being the best-characterized substrates. ${ }^{11-22} \mathrm{Up}$ to now, neddylation has been recognized to be highly activated in various cancers, ${ }^{20,27-33}$ which draws much attraction for oncologic drug discovery, especially on the finding of NEDD8 E1 inhibitor Pevonedistat(MLN4924). ${ }^{10,23-26}$ MLN4924 covalently binds to NEDD8 E1, blocking all CRLs neddylation, ${ }^{7}$ thus causing accumulation of CRL substrates. ${ }^{71}{ }^{10}$ Since MLN4924 possesses immense anti-cancer effects both in vitro and in vivo, ${ }^{10,27,28-43}$ it has been approved for Phase II clinical trials for treatment of human acute myeloid leukemia, non-small cell lung cancer and mesothelioma. ${ }^{29}$ However, as a result of its broad ablation of neddylation, MLN4924 has a series of toxicities. Therefore, alternative targeting specific CRLs may be more potential and safer for cancer treatment. ${ }^{30-32}$

DCN1 (defective in cullin neddylation 1), also called DCUN1D1, DCNL1 or SCCRO, is a 
highly conserved gene and amplified along the 3q26.3 in most squamous cell carcinomas and some other human cancers. ${ }^{33-39}$ As a co-E3 ligase, it binds to the activation complex of CullinRBX1-UBE2M-NEDD8 to increase neddylation efficiency. ${ }^{16,40-42}$ Researchers have found that blocking UBE2M-DCN1 interaction can reduce cullin3 neddylation. ${ }^{30,}$ 32, ${ }^{43}$ Moreover, DCN1 overexpression has been reported to be associated with poor survival outcome, and DCN1 depression significantly reduces cancer cell growth and invasive capacity. 10,33-35, 42, 44-51 Therefore, DCN1 is considered as a promising and attractive anti-cancer target.

From the X-ray crystallographic structure of DCN1 with UBE2M, researchers have confirmed that during neddylation, the N-terminal acetylated UBE2M can dock into the hydrophobic pocket of DCN1 and this pocket could be used for designing DCN1 inhibitors. ${ }^{21,}$ ${ }^{52} \mathrm{Up}$ to now, four papers have reported the discovery of DCN1-UBE2M interaction inhibitors, ${ }^{30-32,43}$ also known as DCN1 inhibitor. NAcM-COV, the first discovered inhibitor, showed highly specific effects on blocking the N-terminal acetylation-dependent interaction of UBE2M with DCN1, resulting in the reduction of CUL1 and CUL3 neddylation in a squamous lung cancer cell line (HCC95). ${ }^{31,43}$ At the same time, Zhou et al, discovered two high-affinity inhibitors DI-591 and DI-404, which can selectively inhibit the neddylation of cullin 3 over other cullins, leading to the accumulation of cullin 3's substrate:NRF2 (Figure 1). ${ }^{30,32}$ In this study, we screened our in-house structurally diverse molecular library (ca.1000 compounds) and finally found a novel and potent pyrimidine-based DCN1-UBE2M interaction mediator DC-1, using both fluorescence polarization (FP) and homogeneous time resolved fluorescence $(\mathrm{HTRF})^{53}$ assays. After extensive structure-activity relationship (SAR) efforts, a potent thiazole contained 5-cyano-6-phenylpyrimidin-based inhibitor DC-2 was discovered (Figure 2). DC-2 
specifically targets DCN1-UBE2M interaction, leading to the inhibition of cullin3 neddylation and the accumulation of NRF2 and NRF2' downstream proteins: HO-1 and NQO1. Our overall findings indicate that DC-2 may serve as a novel lead compound for specific derivatives targeting DCN1-UBE2M interaction.<smiles>C=CC(=O)Nc1ccccc1CN(C(=O)Nc1cccc(C(F)(F)F)c1)C1CCN([C@@H](C)CCC)CC1</smiles>

NAcM-COV<smiles>CCC(=O)N[C@H](Cc1nc2ccc(C(C)C)cc2s1)C(=O)N[C@H](CNC(=O)CCN1CCOCC1)C1CCCCC1</smiles>

DI-591

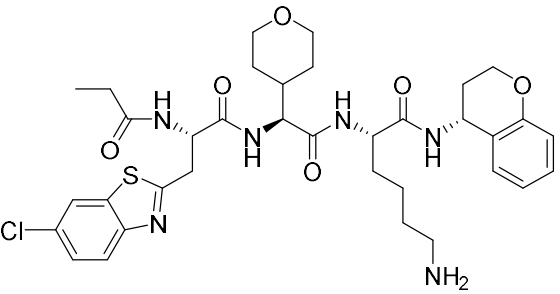

DI-404

Figure 1. Representative examples of DCN1 inhibitors.<smiles>C#CCSc1nc(Sc2nnnn2C)c(C#N)c(-c2ccc3oc(=O)ccc3c2)n1</smiles>

DC-1

$\mathrm{IC}_{50}=1.2 \mu \mathrm{M}$

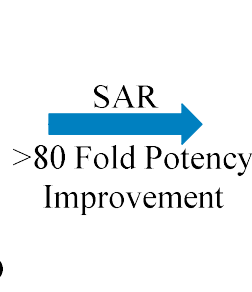

,

DC-2

$\mathrm{IC}_{50}=15 \mathrm{nM}$

Figure 2. Discovery of potent thiazole contained pyrimidin-based inhibitor DC-2.

\section{- RESULTS AND DISCUSSION}

Chemistry. The general synthesis route of the target pyrimidine-thiourea hybrids is depicted in Scheme 1. Benzaldehydes 1a-m, ethyl cyanoacetate $\mathbf{2}$, and thiourea $\mathbf{3}$ were prolonged heated in ethanol containing potassium carbonate to obtain 6-aryl-5-cyano-2-thiouracils $\mathbf{4 a - m}$. Then, compounds 4a-m reacted with the 3-bromoprop-1-yne, 3-bromoprop-1-ene, 1-bromopropane and phosphorus oxychloride in dioxane to obtain the target derivatives 5a-o. ${ }^{54}$ Compound $\mathbf{5 3}$ was prepared via click reaction of compound 5a with benzyl azide. After that, these highly 
activated intermediates (5a-o and 53) were reacted with appropriate mercapto heterocyclics and anilines to obtain compounds 6-52 and $\mathbf{5 4}$.

Scheme 1. Synthesis of the Target Pyrimidine-based Derivatives.
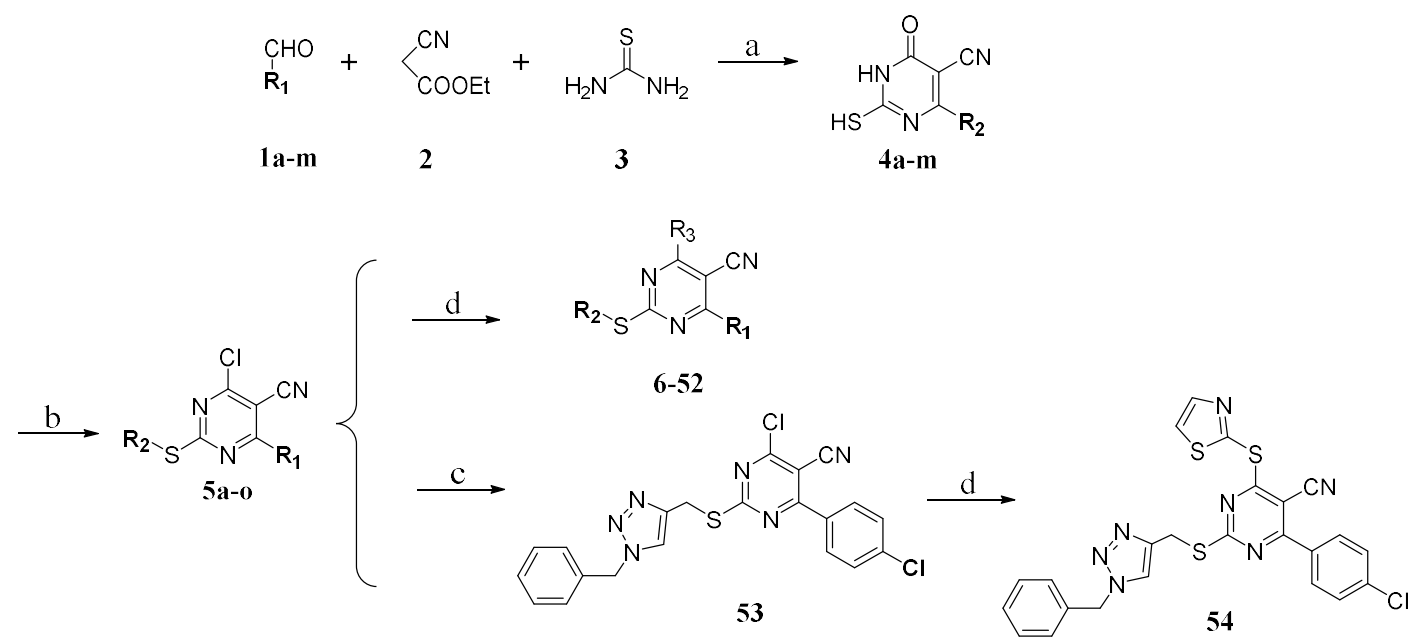

Reagents and conditions: a: absolute ethanol, absolute $\mathrm{K}_{2} \mathrm{CO}_{3}$, reflux, $10 \mathrm{~h}, 70-90 \%$; b: (i) 3bromoprop-1-yne, 3-bromoprop-1-ene, 1-bromopropane, dioxane, reflux; (ii) phosphorous oxychloride, reflux, $1 \mathrm{~h}, 50-80 \%$ (two steps); c: benzyl azide, $\mathrm{CuSO}_{4} \cdot 5 \mathrm{H}_{2} \mathrm{O}$, sodium ascorbate, THF-H2O (1:1), rt, 80\%; d: appropriate mercapto heterocyclic and aniline, absolute ethanol, reflux, $6 \mathrm{~h}, 70-95 \%$.

Development of FP and HTRF Based Competitive Binding Assays. In order to acquire stable and reliable binding affinities of our compounds in vitro, two methods (FP and HTRF) were used for screening DCN1-UBE2M interaction inhibitors. Based on the principle that the $\mathrm{N}$-terminally acetylated UBE2M can interact with $\mathrm{DCN} 1,{ }^{55} \mathrm{UBE}^{\mathrm{N}} \mathrm{M}^{\mathrm{NAcl}-12}$ derivative fluorescently labeled tracer (FAM-782) and His-tagged DCN1 recombinant protein were used to develope the fluorescence polarization (FP) assay. ${ }^{30}$ In addition, human GST-tagged DCN1 recombinant protein (Figure S1A in Supporting Information) and AcUBE2M ${ }^{1-21}$-biotin peptides were applied to establish HTRF screening system. The detailed schematic diagrams are showed 
in Figure 3A and 3B.

A) FP assay for DCN1 binding to UBE2M $M^{\text {Acl-12 }}$ derivative

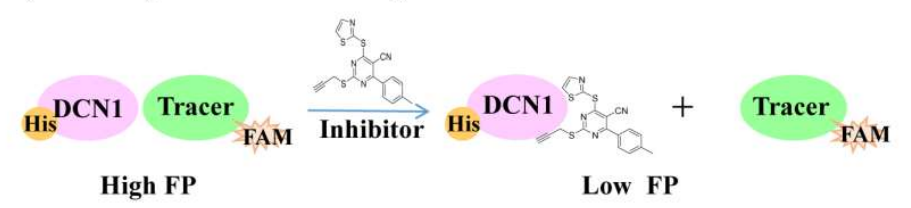

B) HTRF assay for DCN1 binding to UBE2M ${ }^{\text {NAc1-21 }}$

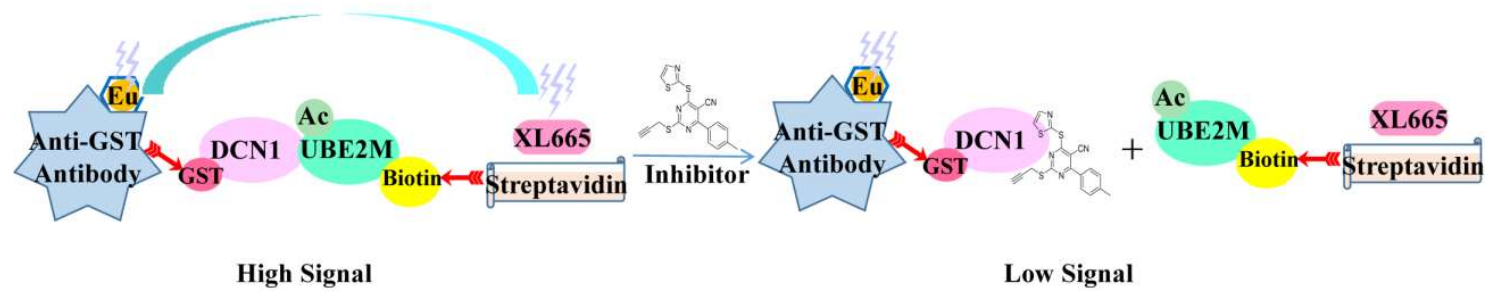

Figure 3. The detailed schematic diagrams for the principle of screening DCN1-UBE2M interaction inhibitors. (A) FP assay for DCN1 binding to UBE2 $\mathrm{M}^{\mathrm{NAc1}-12}$ derivative. The FP value will be decreased after adding the compound, which can inhibit the DCN1-UBE2M interaction. (B) HTRF assay for DCN1 binding to UBE2M ${ }^{\mathrm{NAc1}-21}$. Inhibitors will receive low signal.

\section{Biochemical Activity of the Candidate Compounds Against DCN1-UBE2M Interaction}

and the Structure-Activity Relationship (SAR) Studies. All the compounds synthesized in this study were examined for their inhibitory effects on DCN1-UBE2M interaction in vitro by both FP and HTRF assays. ${ }^{30}$ Compounds DI-591 and NAcM-COV were chosen as positive controls for $\mathrm{FP}^{30}$ and $\mathrm{HTRF}$ assays, ${ }^{43}$ respectively. All $\mathrm{IC}_{50}$ values reported in this study were obtained from at least three independent experiments. The results are summarized as Tables 1-

4.

In order to investigate the effect of coumarin group on inhibitory activity, compounds 7-10 were synthesized initially and their inhibition activities are shown in Table 1. Compared with 
the lead compound DC-1, compounds 7-9 with different heterocyclic substitution at $\mathrm{R}_{1}$ caused a dramatic loss of activity. However, compound $\mathbf{1 0}$ with aromatic ring substitution performed more potent inhibitory effect. These findings indicate that the $R_{1}$ site plays a vital role in influencing their activities and the aromatic ring substitutions at $\mathrm{R}_{1}$ may be more important contributors in determining activity, compared those with coumarin group substitution.

Table 1. Optimizing the Coumarin Group in the Structure of Compound 6(DC-1)

(Compounds 6-10).

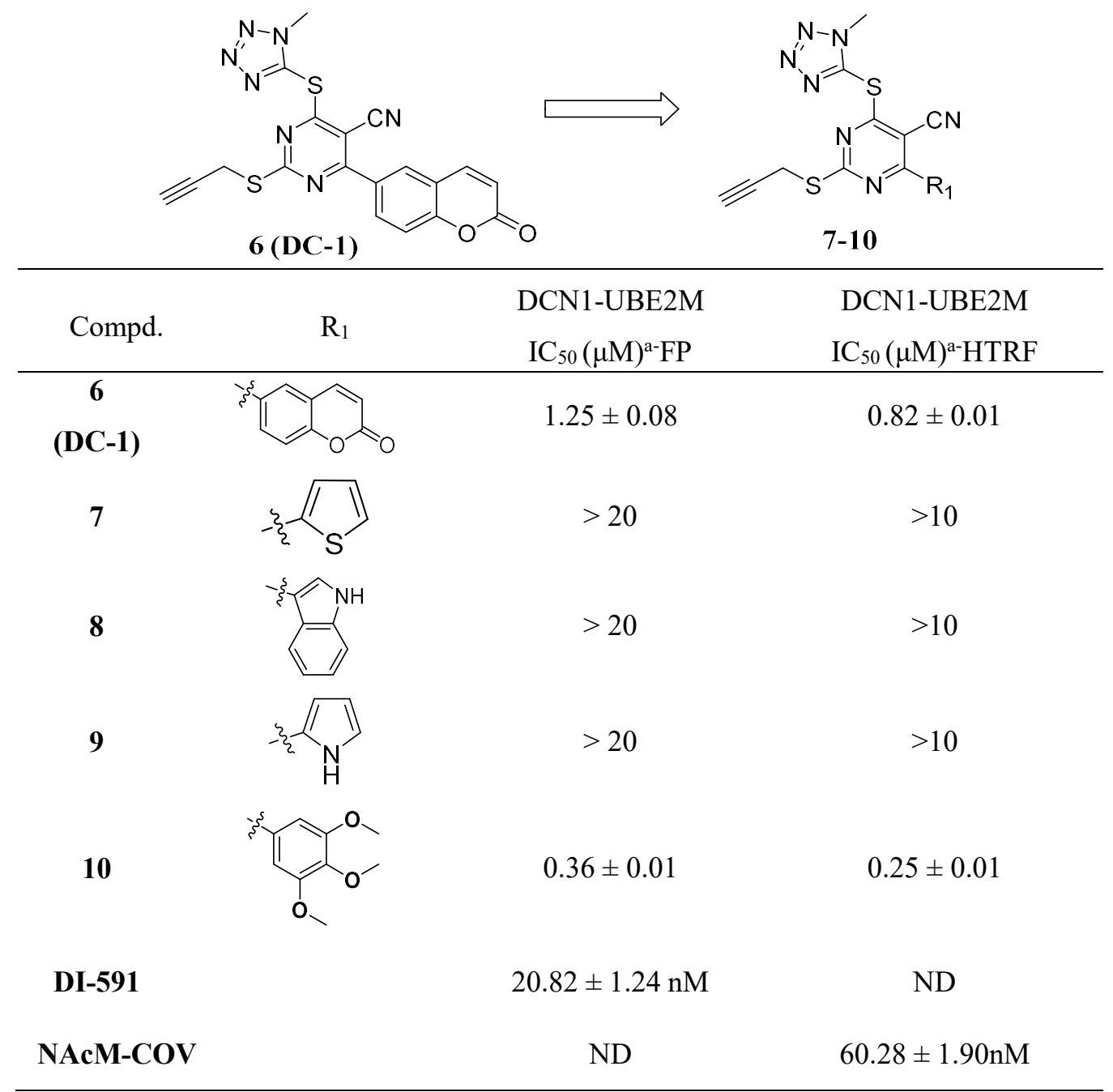

${ }^{\mathrm{a}} \mathrm{IC}_{50}$ values were obtained from three independent repeats and represented as mean $\pm \mathrm{SD}$. ND means the value was not determined. 
Based on the above findings, further modifications were next focused on the substitution pattern and electronic effect on the aromatic ring of compound 10. As shown in Table 2, no matter an electron-withdrawing or -donating group substitution at $\mathrm{R}_{1}$, the acquired compounds 11-17 display increased inhibitory activity compared with no substitution compound $\mathbf{1 8}$. Compounds 11-14 with electron-withdrawing groups at R1 have more potent inhibitory effect compared to compounds 15-17 with electron-donating groups (except 10). The substitution of multiple functional groups on aromatic rings is beneficial to the improvement of activity (11 vs 12, 18 vs 17). Particularly, compound 14 with $\mathrm{p}-\mathrm{Br}$ substitution effectively blocked the DCN1-UBE2M interaction with an $\mathrm{IC}_{50}$ value of $65 \mathrm{nM}$, more potent than $\mathbf{1 2}$ with $\mathrm{p}-\mathrm{Cl}$ substitution. These findings suggest that the number, type and position of substituent and electronic effect on the aromatic ring have significant effects on the activity.

Table 2. Optimization of the Substitution Pattern and Electronic Effect on the Aromatic Ring of Compound 10(Compounds 11-18).

(12)


17<smiles>COc1cccc(C)c1</smiles>

10<smiles>COc1cc(C(C)(C)C)cc(OC)c1OC</smiles>

18
$360.23 \pm 3.64$

$>20000$
$251.13 \pm 2.25$

$>20000$

${ }^{\mathrm{a}} \mathrm{IC}_{50}$ values were obtained from three independent repeats and represented as mean $\pm \mathrm{SD}$. ND

means the value was not determined.

Next, through further structure-activity relationship (SAR) studies, we found that the heteroatoms and different heterocyclic substitutions at $\mathrm{R}_{1}$ were also important for the inhibitory activity (Table 3). Replacing the sulfur atom at $R_{2}$ of compound $\mathbf{1 0}$ with nitrogen atom (19) led to a complete loss of activity. A similar trend was observed by changing the tetrazole-thione to other amino analogues (20-25). In contrast, sulfhydryl heterocyclic substitutions attached to the 4-position of the pyrimidine skeleton were well tolerated. Compared to 10, some of these compounds showed comparably or marginally increased potency, of which $\mathbf{3 4}$ with thiazolethiol group exhibited the most potent activity than other heterocyclic substitutions (2633). The extension of the side chain on nitrogen atom (26) has no significant effect on activity, compared with the corresponding compound 10. In addition, we found that the number of nitrogen atoms on the mercapto heterocycles was important for the inhibitory activity: the tetrazole derivative $\mathbf{1 0}$ was more potent than the pyrazole derivative $\mathbf{2 7}$, and the triazole (28), pyridine (29) derivative without any detectable activity. Particularly, replacement of the nitrogen $(\mathrm{N})$ atom in $\mathbf{2 8}$ with the sulfur $(\mathrm{S})$ atom yielded $\mathbf{3 0}$, which significantly increased the inhibitory activity with an $\mathrm{IC}_{50}$ value of $195 \mathrm{nM}$. A similar trend was also observed in compounds 31-34, which suggested that sulfur atom plays an important role in inhibitory activity. In addition, the introduction of hydrophilic functional groups $(\mathbf{3 2}, \mathbf{3 3})$ reduced the inhibitory activity to some extent. Interestingly, compared to $\mathbf{3 4}$, it was found that derivatizations of the olefinic bond on the thiazolethiol group (35-37) exhibited disappearance 
of activity, which indicated that the increase of steric hindrance at $R_{2}$ was detrimental to the activity.

Table 3. Optimization of the Heteroatoms and Different Heterocyclic Substitutions of Compound 10(Compounds 19-37).

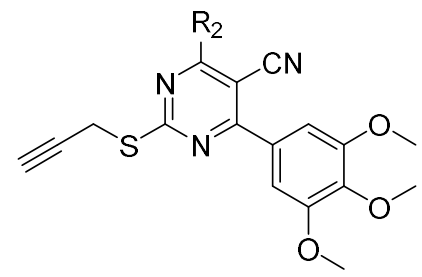

\begin{tabular}{|c|c|c|c|}
\hline Compd. & $\mathrm{R}_{2}$ & $\begin{array}{l}\text { DCN1-UBE2M } \\
\text { IC }_{50}(\mathrm{nM})^{\mathrm{a}-\mathrm{FP}} \\
\end{array}$ & $\begin{array}{l}\text { DCN1-UBE2M } \\
\text { IC }_{50}(\mathrm{nM})^{\mathrm{a}-H T R F}\end{array}$ \\
\hline 19 & & $>10000$ & $>10000$ \\
\hline 20 & & $>10000$ & $>5000$ \\
\hline 21 & & $>10000$ & $>5000$ \\
\hline 22 & & $>10000$ & $>10000$ \\
\hline 23 & & $>10000$ & $>5000$ \\
\hline 24 & & $>10000$ & $>10000$ \\
\hline 25 & & $>10000$ & $>10000$ \\
\hline 26 & & $591.11 \pm 2.75$ & $199.07 \pm 2.29$ \\
\hline 27 & & $1217.90 \pm 1.32$ & $>5000$ \\
\hline 28 & & $>10000$ & $>2500$ \\
\hline 29 & & $>10000$ & $>2500$ \\
\hline 30 & & $195.66 \pm 2.29$ & $65.98 \pm 1.81$ \\
\hline 31 & & $152.82 \pm 2.18$ & $133.60 \pm 2.12$ \\
\hline 32 & & $820.78 \pm 2.91$ & $106.73 \pm 2.02$ \\
\hline
\end{tabular}




\begin{tabular}{|c|c|c|c|}
\hline 33 & $\mathrm{H}_{2} \mathrm{~N}_{Y} \mathrm{~S}_{y} \mathrm{~S}_{5} \mathrm{~s}_{-}$ & $413.55 \pm 2.04$ & $141.22 \pm 2.15$ \\
\hline 34 & & $141.22 \pm 2.10$ & $77.04 \pm 1.88$ \\
\hline $\begin{array}{c}35 \\
(\mathrm{DC}-2 \mathrm{~N})\end{array}$ & & $>10000$ & $>10000$ \\
\hline 36 & & $>10000$ & $>10000$ \\
\hline 37 & & $>10000$ & $>5000$ \\
\hline 10 & & $360 \pm 3.64$ & $251.13 \pm 2.25$ \\
\hline
\end{tabular}

${ }^{\mathrm{a}} \mathrm{IC}_{50}$ values were obtained from three independent repeats and represented as mean $\pm \mathrm{SD}$. ND means the value was not determined.

In order to further investigate the importance of the two sites at $R_{1}$ and $R_{2}$ of $\mathbf{3 4}$, we simultaneously changed them and synthesized compounds 38-50. Compared to $\mathbf{3 4}$, some of these compounds showed comparable potency against DCN1, of which $\mathbf{4 2}$ (also named as DC2) showed the most potent inhibitory effect on the DCN1-UBE2M interaction with an $\mathrm{IC}_{50}$ value of $26 \mathrm{nM}$. In addition, compound $\mathbf{3 9}$ with chlorine substitution in para position at the phenyl ring in $\mathrm{R}_{1}$ displayed more potent inhibitory activity compared to the meta- and disubstituted compounds ( 38 and 41 ). A similar trend was also observed (46 vs $\mathbf{4 7}, \mathbf{4 8}$ ), which suggested that the position of substituent at the phenyl ring in R1 plays an important role in the inhibitory activity. Furthermore, replacement of the phenyl group at $\mathrm{R}_{1}$ with aromatic heterocycle yielded $\mathbf{4 3 - 4 5}$, which significantly decreased the inhibitory activity, as well as 4649 vs 50, which further suggested that the position of substituent and electronic effect at $R_{1}$ were important for the activity. Moreover, the importance of terminal alkyne moiety was also evaluated. Due to the change of the propargyl group to ethene or ethyl group, compounds $\mathbf{5 1}$ and 52 exhibited no detectable (>10000nM) DCN1-UBE2M inhibitory effect compared to 39, which may be related to the hydrophobic interactions by forming $\pi-\pi$ stacking with DCN1UBE2M. In addition, replacing the propargyl group by triazole via click chemistry caused a 
dramatic loss of activity ( $\mathbf{5 4}$ vs $\mathbf{3 9}$ ), which indicated that the increase of steric hindrance at $\mathrm{R}_{3}$ was detrimental to the activity. These modifications and SAR studies reveal that the terminal alkyne group is also critical for their inhibitory activity, and the introduction of hydrophobic functional groups of appropriate size at $\mathrm{R}_{3}$ may be beneficial to the improvement of activity.

Table 4. Optimization of the Aromatic and Heterocyclic Substitutions at R1, R2 and R3 of Compound 34(Compounds 38-54).

(DC-2)


48<smiles>[Y]c1ccc(Cl)c(Cl)c1</smiles><smiles>CN(C)CCn1nnnc1N</smiles><smiles>C#CCC(C)C</smiles>

$109.04 \pm 2.03$

$119.80 \pm 2.07$

49<smiles>Cc1ccc(C)cc1</smiles><smiles>CN(C)CCn1nnnc1I</smiles><smiles>C#CCCCCCCCCC</smiles>

$390.85 \pm 2.56$

$172.29 \pm 2.23$

50<smiles>[Y]c1ccc2oc(=O)ccc2c1</smiles><smiles>CN(C)CCn1nnnc1S</smiles><smiles>C1#CCCCC1</smiles>

$665.64 \pm 2.74$

$814.60 \pm 2.91$

51<smiles>[Y][14c]1ccc(Cl)cc1</smiles>

52<smiles>[Y][14c]1ccc(Cl)cc1</smiles><smiles>[As]C(=[As])c1nccs1</smiles><smiles>C=CCCCC</smiles>

$>10000$

$>10000$

$>10000$

$>10000$

54<smiles>[Y]c1ccc(Cl)cc1</smiles><smiles>[As]=C1CC=CS1</smiles><smiles>CCCCCC</smiles><smiles>[As]c1nccs1</smiles><smiles>CC1=CN(C)CN1</smiles>

$>10000$ $>10000$

${ }^{\mathrm{a}} \mathrm{IC}_{50}$ values were obtained from three independent repeats and represented as mean $\pm \mathrm{SD}$. ND means the value was not determined.

A

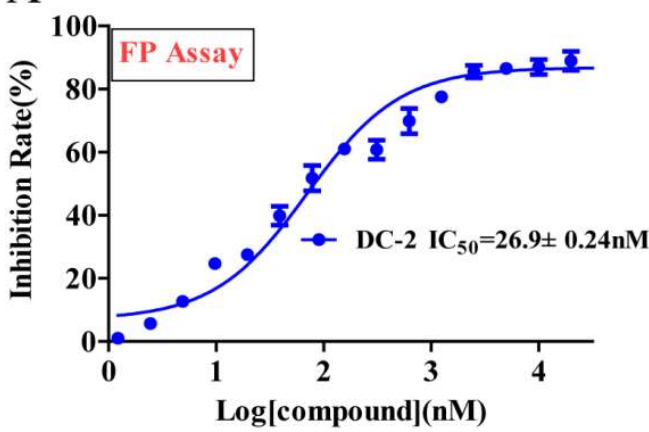

B

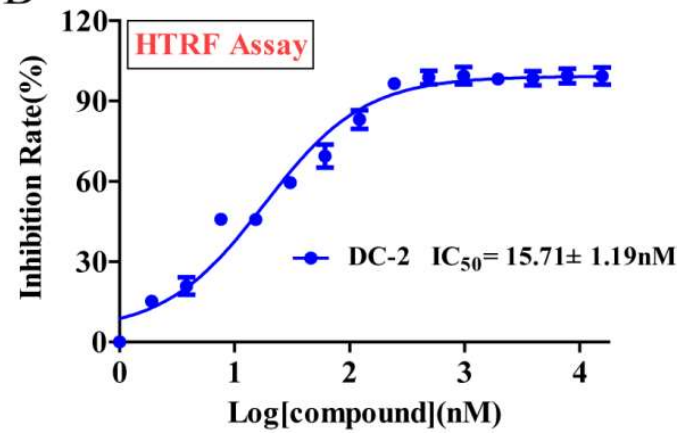

Figure 4. Compound DC-2(compound 42) combines with DCN1 and thus inhibits UBE2MDCN1 interaction in vitro. Compound DC-2 was added into the screening systems and its inhibition rates (\%) at different concentration were determined by both FP (A) and HTRF (B) assays, respectively. Data are presented as means \pm SD. Three individual experiments were performed for each group.

In summary, starting from a potent pyrimidine-based DCN1-UBE2M interaction mediator DC-1(compound 6) in our in-house structurally diverse molecular library (ca.1000 compounds), DC-2 (compound 42) containing 5-cyano-6-phenyl-pyrimidin was finally obtained with MW of 380 , two $\mathrm{IC}_{50}$ values $26.89 \pm 0.24\left(\mathrm{~K}_{\mathrm{i}}=20.83 \pm 0.18 \mathrm{nM}\right)$ and $15.71 \pm 1.19 \mathrm{nM}\left(\mathrm{K}_{\mathrm{i}}=13.66 \pm\right.$ 
$1.03 \mathrm{nM}$ ) from the FP and HTRF assays (Figure 4A and 4B), respectively, resulting in about 80fold improved potency. Furthermore, DC-2 has aqueous solubility in phosphate buffer (PBS, $\mathrm{pH}$ 7.4) to some extent (Figure $\mathrm{S} 2$ in Supporting Information). Therefore, DC-2 was chosen for the following target activity evaluation experiments. The compound 35 (DC-2N), which had the similar structure with DC-2 but presented no obvious inhibitory effect on DCN1-UBE2M interaction $\left(\mathrm{IC}_{50}>10 \mu \mathrm{M}\right)$, was chosen as a negative control.

DC-2 Binds to DCN1 and Increases Its Stability in Vitro. Next, the protein thermal shift assay was conducted to assess that whether DC-2 can directly bind to DCN1 and adjust its stability in vitro ${ }^{56,57}$ As shown in Figure 5, compared with DMSO control and DC-2N, DC-2 obviously caused about $7{ }^{\circ} \mathrm{C}$ increase of the DCN1 melting temperature, similar to the effects of the positive control NAcM-COV. These findings indicate that DC-2 can directly bind to DCN1 and thus raise its thermal stability in vitro.

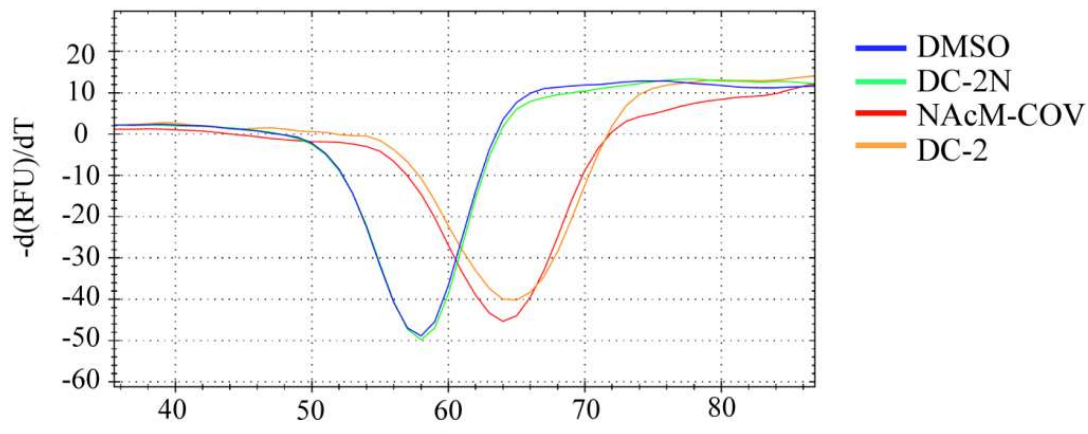

Figure 5. Compound DC-2 increases the stability of DCN1 in vitro. Normalized thermal shift assay response for recombinant human DCN1 in the presence of $0.5 \mathrm{mM}$ DC-2 (orange) and DC-2N (green). NAcM-COV (red) was used as a positive control. DMSO (blue) was used as a blank control. Three individual experiments were performed for each group.

Binding Affinities of DC-2 on DCN Proteins. Previous studies have reported that there are five DCN1 homologues (DCNs: 1 to 5 ) in humans, ${ }^{33,50}$ which contain a highly conserved central and C-terminal PONY domain, but possess distinct N-terminal regions. ${ }^{33,50,58,59}$ The DCN1-5 PONY domains can interact with cullins to stimulate neddylation with different 
efficiencies. ${ }^{55,60}$ Therefore, we further measured the binding affinities of DC-2 on DCN1 to 5 through competitive binding assay. As shown in Table 5, DC-2 also has high binding affinity on DCN2, whose PONY domain in human shares $82 \%$ identity to that of DCN1 ${ }^{43}$ However, it shows relatively weak binding effects $\left(\mathrm{K}_{\mathrm{i}}>500 \mathrm{nM}\right)$ on DCN3-5, compared to that of DCN1. These data suggest that DC-2 has specificity and selectivity for DCN1 and 2, similar to the previously reported inhibitors (DI-591, NAcM-COV and DI-404). ${ }^{30,32,43}$

Table 5. Binding Affinities of Compound DC-2 on the Indicated DCN1-5 Recombinant Proteins.

\begin{tabular}{cccccc}
\hline & DCN1 & DCN2 & DCN3 & DCN4 & DCN5 \\
& $\mathrm{K}_{\mathrm{i}}(\mathrm{nM})^{\mathrm{a}}$ & $\mathrm{K}_{\mathrm{i}}(\mathrm{nM})^{\mathrm{a}}$ & $\mathrm{K}_{\mathrm{i}}(\mathrm{nM})^{\mathrm{a}}$ & $\mathrm{K}_{\mathrm{i}}(\mathrm{nM})^{\mathrm{a}}$ & $\mathrm{K}_{\mathrm{i}}(\mu \mathrm{M})^{\mathrm{a}}$ \\
\hline DC-2 & $13.66 \pm 1.03$ & $66.19 \pm 1.72$ & $591.72 \pm 5.17$ & $807.01 \pm 9.42$ & $2.14 \pm 0.32$ \\
\hline
\end{tabular}

${ }^{\mathrm{a}} \mathrm{K}_{\mathrm{i}}$ values were obtained from three independent repeats and represented as mean $\pm \mathrm{SD}$. ND means the value was not determined.

Furthermore, since the N-terminal domain of UBE2M has interaction with both DCN1 and NEDD8 E1 subunit UBA3, ${ }^{52,61}$ we intended to determine whether DC-2 also has inhibitory effects on E1's activity and UBE2M neddylation. As shown in Figure 6A and 6B, in the cellfree NAE activity assay, even though MLN4924 significantly inhibits UBE2M neddylation, compound DC-2 exhibits no obvious effect on NEDD8 UBE2M at concentration up to 100 $\mu \mathrm{M}$, indicating that compound DC-2 has no effect on E1's activity through ATP initiation and UBE2M neddylation.

A

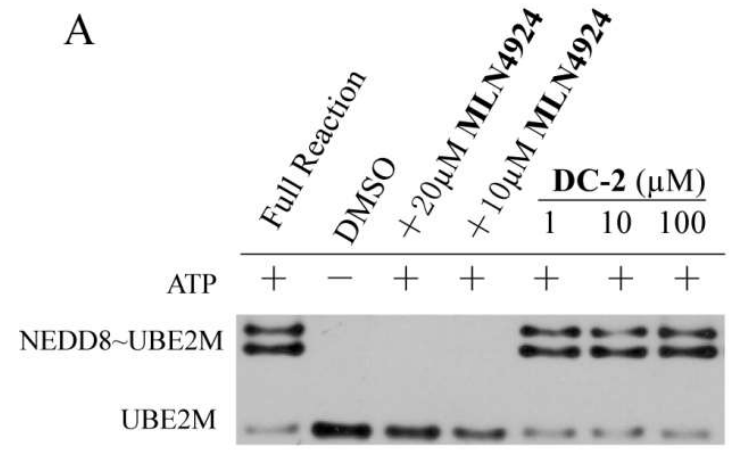

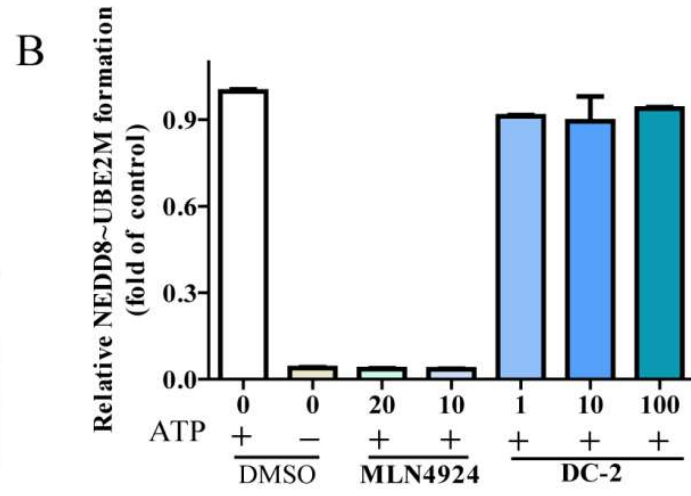


Figure 6. Compound DC-2 exhibits no obvious inhibitory effect on UBE2M neddylation level in vitro. (A) After adding 10 and $20 \mu \mathrm{M}$ MLN4924 or 1, 10 and 100 $\mu$ M DC-2 into the NEDD8, NEDD8 E1 and UBE2M complex, respectively, the NEDD8 UBE2M formation was initiated by ATP. (B) Densitometry shows relative protein expression level, which was analyzed by fold of DMSO with ATP group. Data are presented as means \pm SD. Three individual experiments were performed for each group.

Molecular Docking of DC-2 and DCN1. To investigate the binding mode of compound DC-2 with human DCN1, molecular docking study adopting the software MOE (The Molecular Operating Environment) version 2015.10 was carried out. Since the X-ray structure (PBD ID: $3 \mathrm{TDU}^{52}$ ) obtained from the RSCB Protein Data Bank is the crystal structure of DCN1 in a complex with the N-terminal-acetylated UBE2M peptides and cullin 1, and our inhibitors were found based on the principle that inhibitors compete with the N-terminal-acetylated UBE2M peptides to interact with DCN1, 3TDU was thus selected as the receptor to acquire the binding mode of DC-2 with DCN1. As shown in Figure 7A and 7B, compound DC-2 can be successfully docked into the active site of DCN1. There are 12 of 20 top-score docking conformations, which adopt the similar docking pose. Among them, the conformation with the highest score is illustrated in Figure 7A. Nitrogen atom of cyan group of DC-2 forms a hydrogen bond with the hydroxyl group of the side chain of Tyr181 with a distance of $2.09 \AA$. Sulfur atom connecting thiazole ring of DC-2 forms a non-traditional hydrogen bond with the carbonyl group of the backbone of Pro97 with a distance of $3.55 \AA$. Besides, the methylbenzene group of DC-2 forms arene-H interaction with Phe164. The binding pocket surface of DCN1 and compound DC-2 is shown in Figure 7B. The methylbenzene group of DC-2 is buried into the inside hydrophobic pocket surrounded by Phe117, Phe89, Ile86, Ala106, Val102 and 
Leu103. The propargyl group of DC-2 is located in the hydrophobic regions, which formed by Gln87, Ile83, Ile86 and Cys115. In addition, the thiazole ring of DC-2 forms hydrophobic interactions with Tyr181, Leu184 and Met177. All these computer-based predicated interactions indicate that compound DC-2 could be well and specifically docked into the binding pocket of DCN1.

A

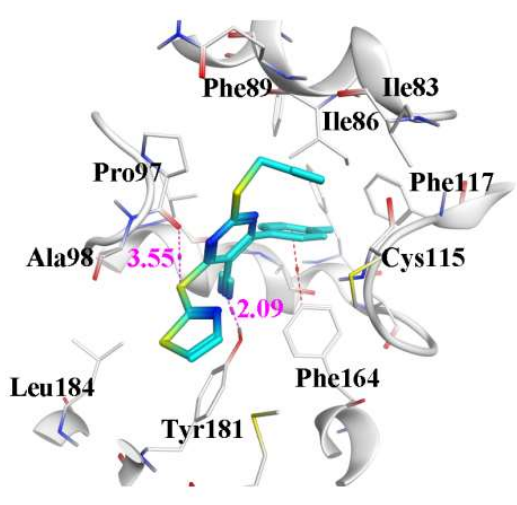

$\mathrm{C}$

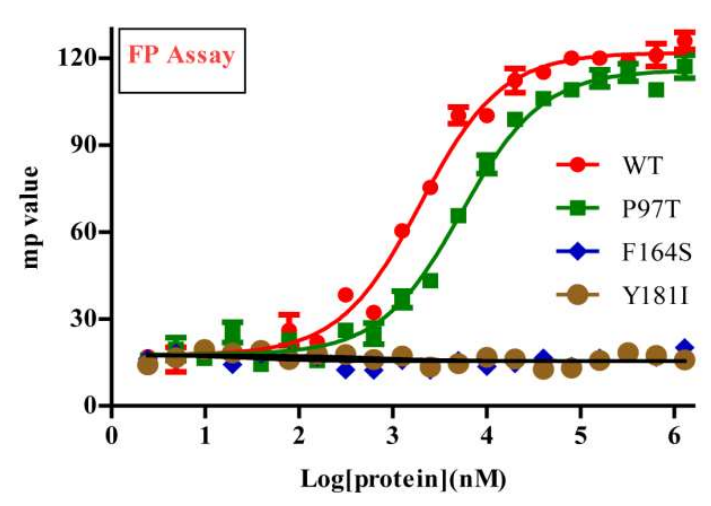

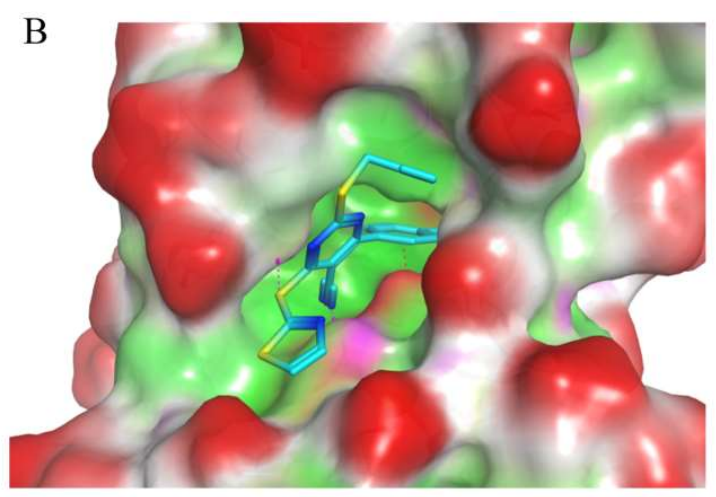

$\mathrm{D}$

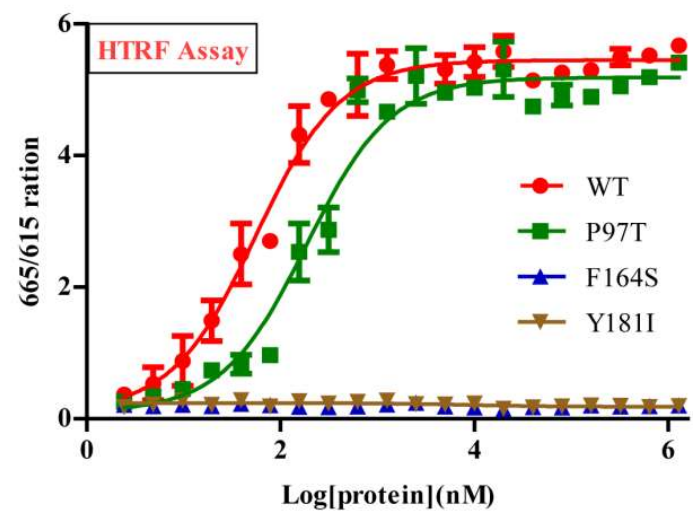

Figure 7. Predicted binding mode of compound DC-2 in DCN1 binding pocket (PDB ID: 3TDU). (A) Residues forming interactions in the docked complex. Compound DC-2 is shown as cyan stick; the residues associated with the compound are shown in white lines. Hydrogen bonds are shown in magenta dash lines and arene-H interaction is shown in red dash line. The corresponding distances are given in $\AA$. (B) The binding pocket surface of DCN1 and compound DC-2. Green area represents hydrophobic region and red area represents exposed solvent region. The $\mathrm{mp}$ values(C) and 665/615 ratios (D) were determined after adding increased concentration of recombinant wild type (WT) DCN1 or its site specific mutations: 
P97T, F164S and Y181I. Data are presented as means \pm SD. At least three individual experiments were performed for each group.

Site Specific Mutations in DCN1 Binding Pockets with DC-2. Previous studies have reported that the Pro97, Phe164 and Tyr181 residues of human DCN1 are involved in the interaction of DCN1 and UBE2M, especially Tyr181, which can clamp the UBE2M's N-acetylMet1 and Ile2, pressing UBE2M's N-acetyl-Met into DCN1's hydrophobic pocket. ${ }^{52,}{ }^{55}$ In addition, the reported DCN1-UBE2M interaction inhibitors all have interactions with these three residues, either by forming hydrogen bonds or fitting into the hydrophobic pocket. ${ }^{30,32,43}$ Therefore, we hypothesize that these three residues may play an important role in DCN1UBE2M interaction. Furthermore, our above docking results also have confirmed that DC-2 has relatively strong interactions with Pro97, Phe164 and Tyr181 residues of DCN1 (Figure 7A and 7B). Therefore, we speculate that the inhibitory effects of compound DC-2 on DCN1UBE2M interaction may be also related to these three amino acid residues. To prove our hypothesis, the three residues of DCN1 (Pro97, Phe164 and Tyr181) were chosen to do the site specific mutations to Thr97 (P97T), Ser164 (F164S) and Ile181 (Y181I), whose physicochemical properties are totally different from their original amino acids, respectively (Figure S1C in Supporting Information). In our in vitro FP and HTRF assays, we found the complete loss of mp values and 665/615 ratios in DCN1 F164S and Y181I mutations, indicating that there is no interaction between the DCN1 mutations and AcUBE2M ${ }^{1-21}$-biotin peptides. However, these parameters in DCN1 P97T mutation remained almost the same as those in wild type DCN1, indicating that P97T mutation did not affect its binding affinity with AcUBE2M ${ }^{1-}$ ${ }^{21}$-biotin (Figure 7C and 7D). To confirm this discovery, we further did the label-free BioLayer Interferometry (BLI) assay. Consistent with our above findings, DCN1 F164S and Y181I mutations lost the binding affinity with AcUBE2M ${ }^{1-21}$-biotin peptide rather than DCN1 P97T mutation (Figure S3 in Supporting Information). All these findings suggest that both Phe164 and Tyr181 residues are crucial for DCN1-UBE2M interaction and the inhibition effect of DC2 may be related to its binding interaction with these two residues. 
DCN1 was Highly Activated in Several Human Cancer Cell Lines. In order to choose suitable cancer cell lines for the further experiments, the DCN1 protein levels in several human cancer cell lines, including lung cancer cell lines (PC9, A549 and H1975), esophageal cancer cell lines (EC109, EC9706, KYSE70, KYSE140 and TE-1), liver cancer cell lines (SMMC7721, BEL-7402 and ZIP177), prostatic cancer cell line (PC3) and breast cancer cell line (MCF7) were measured. We found that DCN1 was highly expressed in these cancer cell lines, compared with those in normal cell lines: GES-1, Het-1A and L02, respectively (Figure 8A-C).
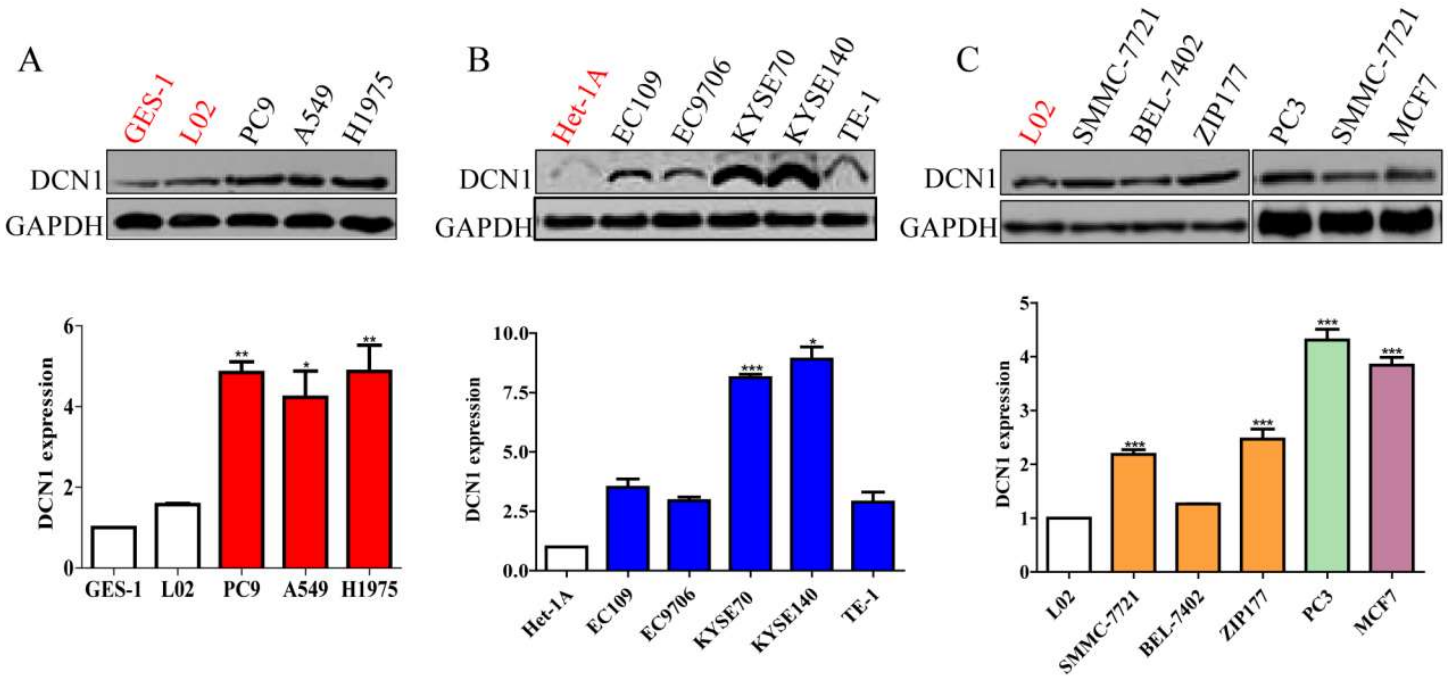

Figure 8. The expression levels of DCN1 in several human cancer cell lines. (A) Lung cancer cell lines: PC9, A549 and H1975. (B) Esophageal cancer cell lines: EC109, EC9706, KYSE70, KYSE140 and TE-1. (C) Liver cancer cell lines: SMMC-7721, BEL-7402 and ZIP177; prostate cancer cell line: PC3 and breast cancer cell line: MCF7. Data are presented as means \pm SD. At least three individual experiments were performed for each group. ${ }^{*} \mathrm{P}<0.05$, ** $\mathrm{P}<0.01$, *** $\mathrm{P}<0.001$ as compared with the normal control cell lines: GES-1, Het-1A or L02, respectively.

Interaction of DC-2 with DCN1 at Cellular Level. To further determine whether DC-2 can target intracellular DCN1, cellular thermal shift assay (CETSA) was performed in one of the DCN1 overexpressed cancer cell line H1975. As shown in Figure 9A and 9D, DCN1 protein started to degrade at $53^{\circ} \mathrm{C}$ in DMSO or $10 \mu \mathrm{M}$ DC-2N treated cells (Figure 9A, 9B, 9D and 9E). 
While, it was very stable from 43 to $61^{\circ} \mathrm{C}$ in the $10 \mu \mathrm{M}$ DC-2 treated cells, similar to that treated by positive compound DI-591(Figure 9A and 9D). ${ }^{30}$ In addition, DC-2 increases DCN1 thermal ability at concentration low to $1 \mu \mathrm{M}$ at $55^{\circ} \mathrm{C}$ (Figure 9B and 9E). These findings indicate that DC-2 can engage the cellular DCN1 protein and increase its thermal ability. Furthermore, the DCN1 level, which was pulled down by UBE2M antibody, was obviously decreased in DC-2 treated cells, compared with those in DMSO or DC-2N treated groups (Figure 9C and 9F). These findings further suggest that compound DC-2 can bind to DCN1 and inhibit the association of UBE2M and DCN1 at cellular level.

A

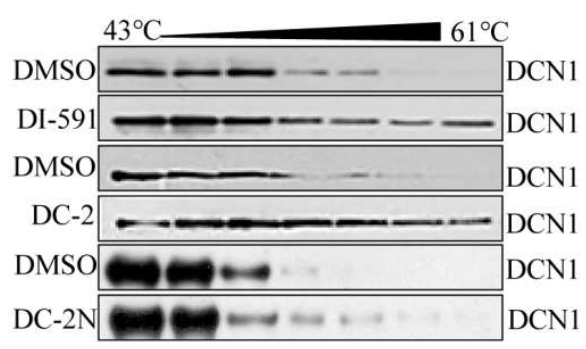

B

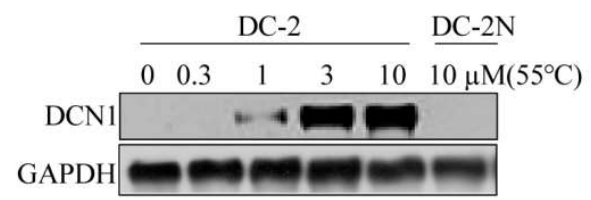

$\mathrm{D}$

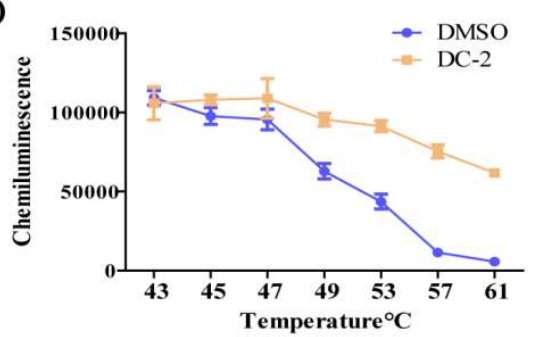

E

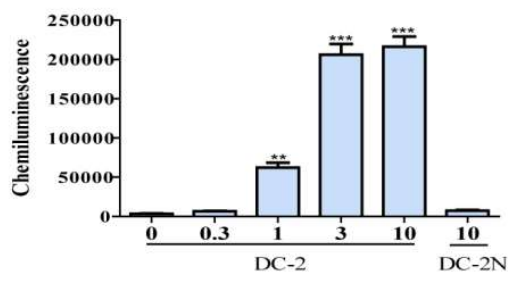

$\mathrm{C}$
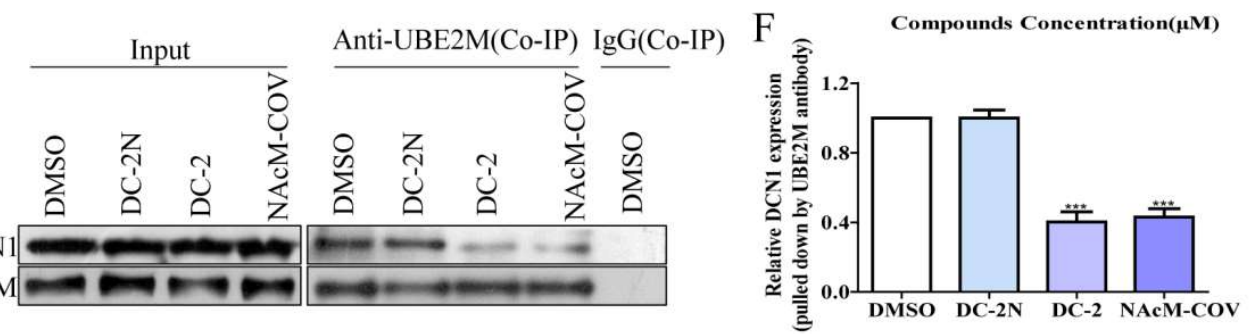

Figure 9. Compound DC-2 specifically binds to DCN1 and blocks the interaction of DCN1UBE2M at cellular level. (A and B) H1975 cells were treated with $10 \mu \mathrm{M}$ compound DC-2, DI591 or DC-2N for $5 \mathrm{~h}$, respectively. Then, they were collected and heated from $43^{\circ} \mathrm{C}$ to $61^{\circ} \mathrm{C}$ (A). H1975 cells were treated with $0,0.3,1,3,10 \mu \mathrm{M}$ DC-2 or $10 \mu \mathrm{M}$ DC-2N before being heated at $55^{\circ} \mathrm{C}$. Then their DCN1 expression levels were determined by Western Blot (B). (C) Compound DC-2, but not DC-2N blocks the association of DCN1 and UBE2M at cellular level. After H1975 cells were treated with compound DC-2N, DC-2 or NAcM-COV, the protein 
levels of UBE2M and DCN1, which were pulled down by UBE2M antibody, were determined by Western Blot (right panel). The basal levels of DCN1 and UBE2M in cell lysates were determined by Western Blot (left panel). (D-F) The bands intensities of proteins in figure A-C, respectively. At least three individual experiments were performed for each group.

Selectively Blocking the Neddylation of Cullin3 by DC-2 in Lung Cancer Cells. Human DCN1 acts as a co-E3 ligase, which can interact with cullins and Rbx1 to stimulate the neddylation of cullins in vivo, especially cullin $1-4 .{ }^{21,40,52,55,60,62}$ In order to examine the effect of DC-2 on the neddylation of cullins at cellular level, two DCN1 highly expressed lung cancer cell lines H1975 and PC9 were treated with compound DC-2 for 24h, using DC-2N or MLN4924 as a negative or positive control, respectively. We found that DC-2 treatment resulted in a significantly decreased cullin3 (CUL3) neddylation level, without obvious impact on the neddylation of other cullins (CUL1, CUL2, CUL4A, CUL4B and CUL5, Figure 10A) in both cell lines. In addition, since the inhibition of the cullins neddylation has been associated with the accumulation of its substrates, the expression levels of nuclear factor-erythroid 2 related factor 2(NRF2) (one substrate of cullin3), ${ }^{63-65}$ as well as NRF2's downstream proteins (NADPH: quinone oxidoreductase-1, NQO1) and (Heme oxygenase-1, HO-1) were then determined after DC-2 treatment. ${ }^{66-68}$ We found that the expression levels of NRF2, HO-1 and NQO1 were obviously increased in both H1975 and PC9 cells, similar to the findings treated by MLN4924 (MLN, Figure 10C). But the expression levels of CylinE1, p21 (two substrates of cullin1) and CDT1 (a substrate of cullin4A) were not changed after DC-2 treatment (Figure 10C). ${ }^{66-68}$ Furthermore, the inhibition effects on the neddylation of cullin3 (Figure 10B, 10E, $10 \mathrm{G}$ and $10 \mathrm{H}$ ) as well as the accumulation of NRF2, NQO1 and HO-1 (Figure 10D, 10F, 10G and $10 \mathrm{H})$ exhibited in a dose $(0.3,1,3,10$ and $20 \mu \mathrm{M})$ and time dependent manner $(0.5,1,3$, 
12, 24 and 48h), without significant effect on the neddylation of other cullins (CUL1-5) (Figure 10B) and their conresponding substrates: CylinE1, p21 and CDT1 (Figure 10D and 10G) in both H1975 and PC9 cells. These findings indicate the specifically inhibitory effects of DC-2 on the neddylation of cullin3 at cellular level, without significant effects on other cullins neddylation.

Moreover, silencing DCN1 by three small interfering RNA (siRNA) in both PC9 and H1975 cells also decreased the neddylation of cullin3 and caused the accumulation of NRF2, NQO1 and HO-1(Figure 11A-C). Furthermore, DC-2 treatment did not have additive effect on them (Figure 11D-F). These results further confirm that the effect of DC-2 on the neddylation of cullin3 is through its specific binding to DCN1. 
A

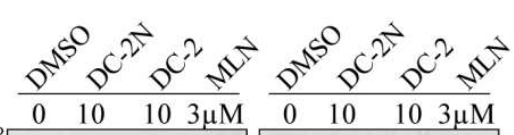

$\begin{array}{lllllllll}0 & 10 & 10 & 3 \mu \mathrm{M} & 0 & 10 & 10 & 3 \mu \mathrm{M}\end{array}$

Cul1 $=\approx=0$

$\mathrm{Cul}_{\mathrm{Cu} 2}^{\mathrm{N} 8}=\mathrm{CE}$

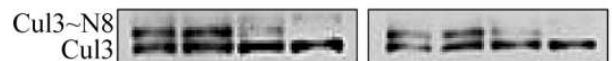

Cul4A N8 $\mathrm{Cul4A}=$

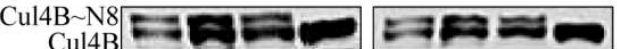

$\mathrm{Cul} 4 \mathrm{~B}$

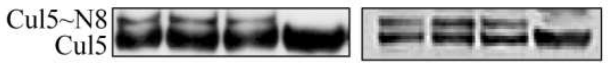

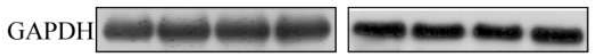

PC9

H1975

C

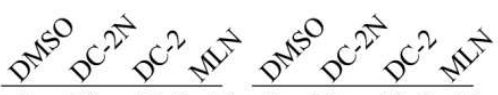

NRF2 \begin{tabular}{lllllllll}
0 & 10 & 10 & $3 \mu \mathrm{M}$ & 0 & 10 & 10 & $3 \mu \mathrm{M}$ \\
\hline & & & 0 & & &
\end{tabular}

$\mathrm{HO}-1 \backsim \omega-\infty$

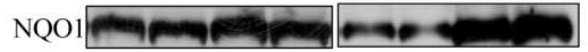

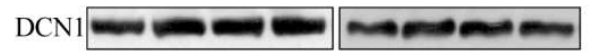

$\mathrm{P} 21 \longrightarrow-\cdots+\infty \mathrm{C}$

CDT1

CylinE1

GAPDH

E

PC9

H1975

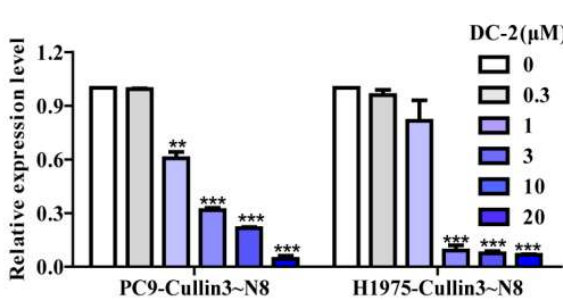

G

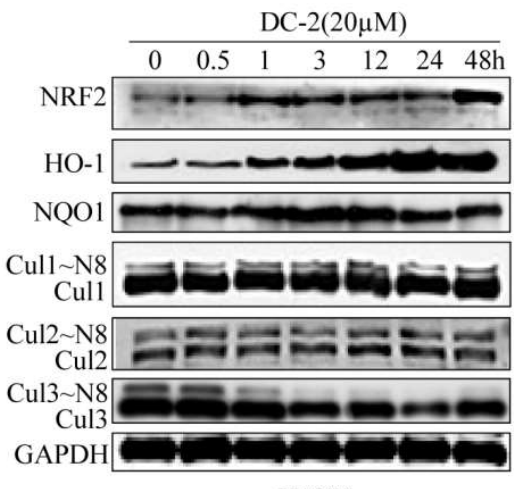

H1975
B

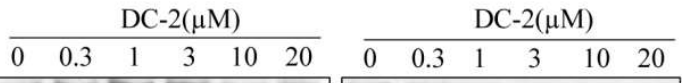

$\mathrm{Cull} \sim \mathrm{N} 8$
$\mathrm{Cul1}$

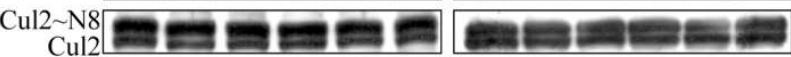

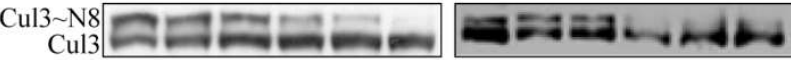

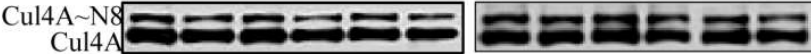

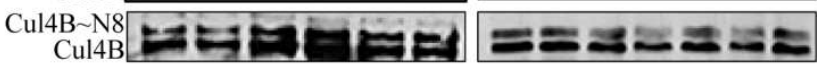
Cul5 N8 $\longrightarrow$ $\mathrm{Cul} 5 \mathrm{C}$ GAPDH

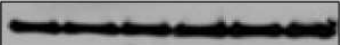

PC9

H1975

D
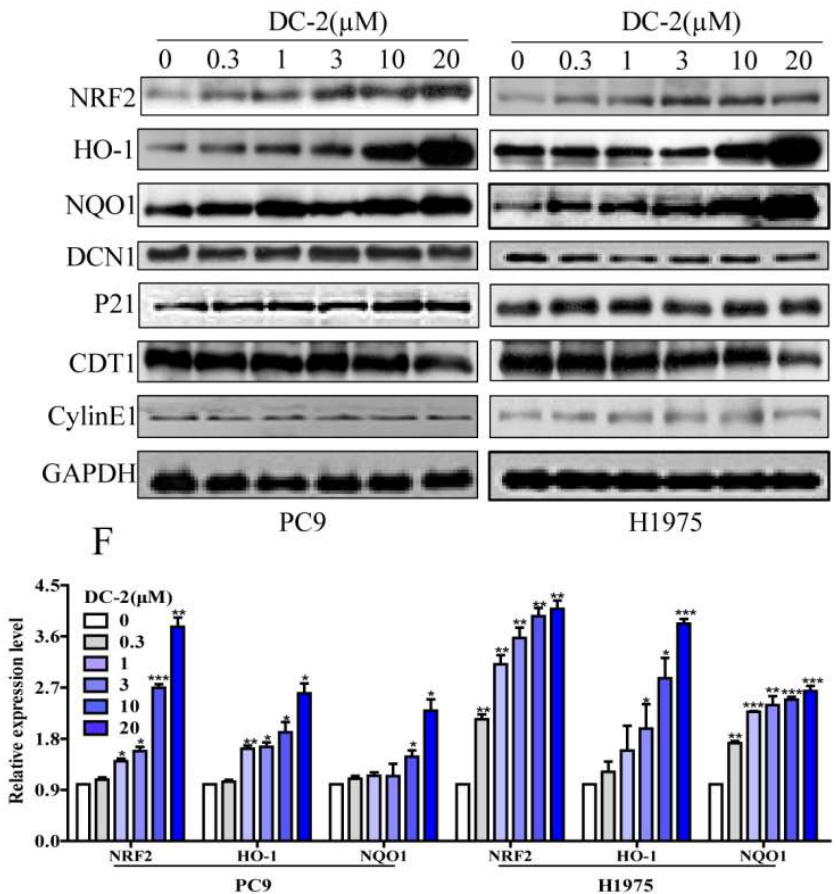

$\mathrm{H}$

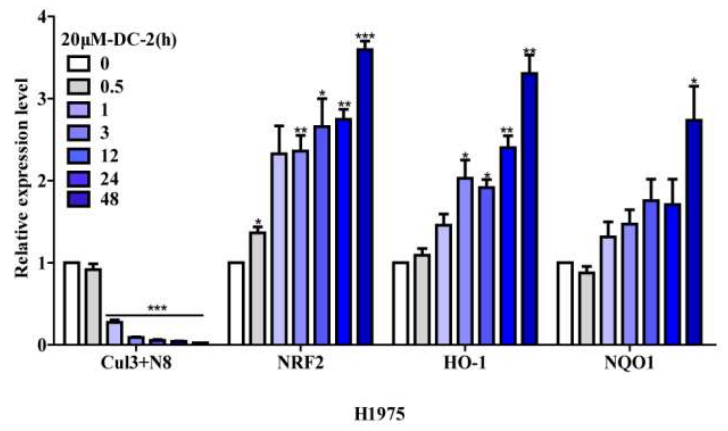

Figure 10. Compound DC-2 inhibits intracellular cullin3's neddylation process and subsequently increases its substrate NRF2 as well as NRF2' downstream proteins: HO-1and NQO1 with time ( $\mathrm{G}$ and $\mathrm{H}$ ) and dose (A-F) dependent manner. Densitometry shows relative 
protein expression level normalized by GAPDH. Data are presented as means \pm SD. Three individual experiments were performed for each group. ${ }^{*} \mathrm{P}<0.05$, ** $\mathrm{P}<0.01$, *** $\mathrm{P}<0.001$ as compared with the DMSO controls.
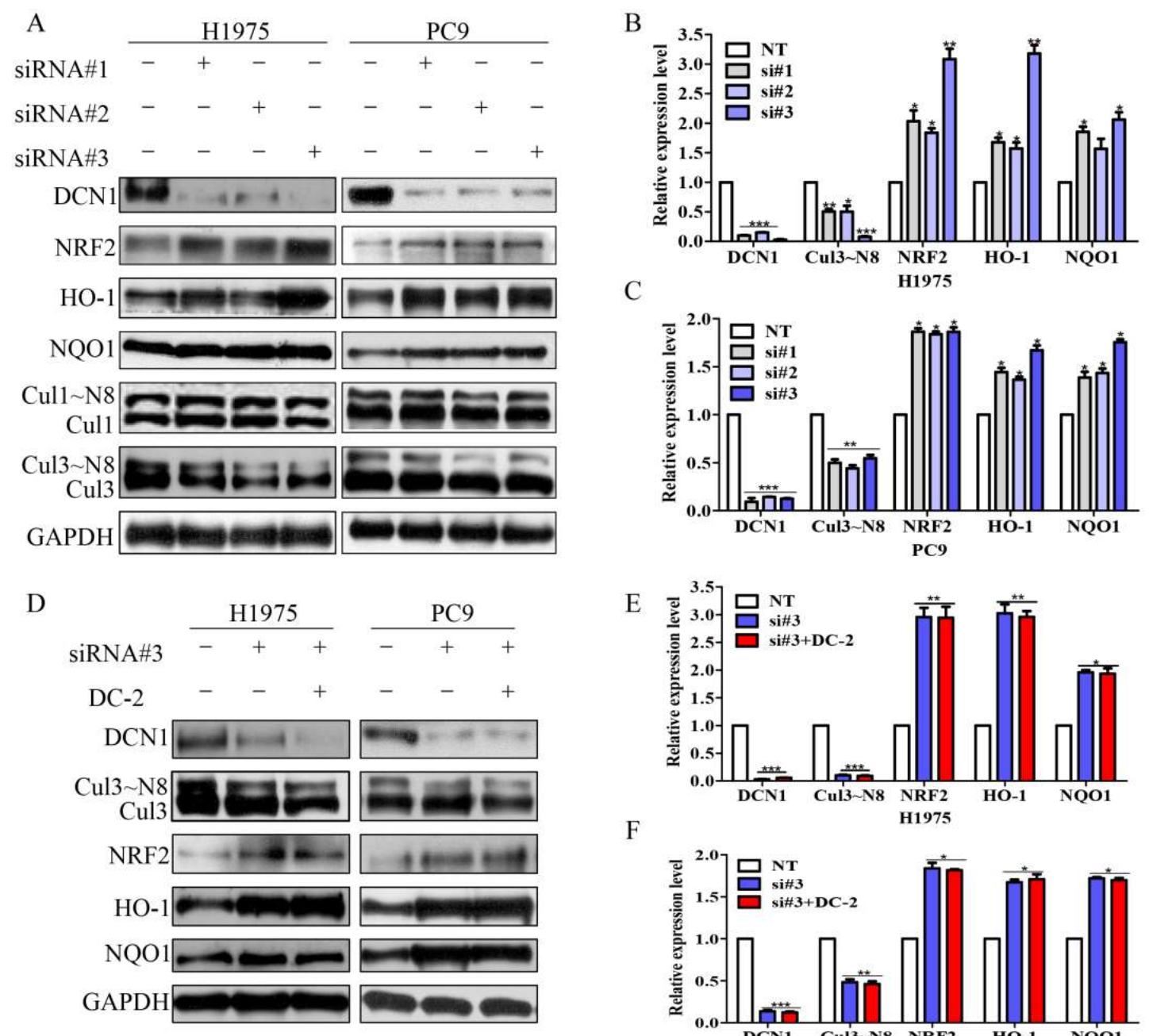

$\mathrm{F}$

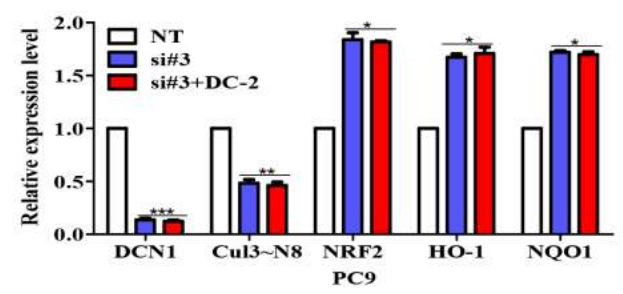

Figure 11. The protein levels of DCN1, NRF2, HO-1, NQO1, Cullin1 and Cullin3 were measured after H1975 and PC9 cells were treated with three DCN1 siRNA (A). Non-targeting siRNA (NT) treatment was used as control. (D) The protein levels of Cullin3, DCN1, NRF2, HO-1 and NQO1 were determined after treating the H1975 and PC9 cells by siRNA\#3 with or without compound DC-2. (B, C, E and F) Densitometry shows relative protein expression level normalized by GAPDH. Data are presented as means \pm SD. Three individual experiments were performed for each group. ${ }^{*} \mathrm{P}<0.05$, ** $\mathrm{P}<0.01$, *** $\mathrm{P}<0.001$ as compared with the controls 
(NT).
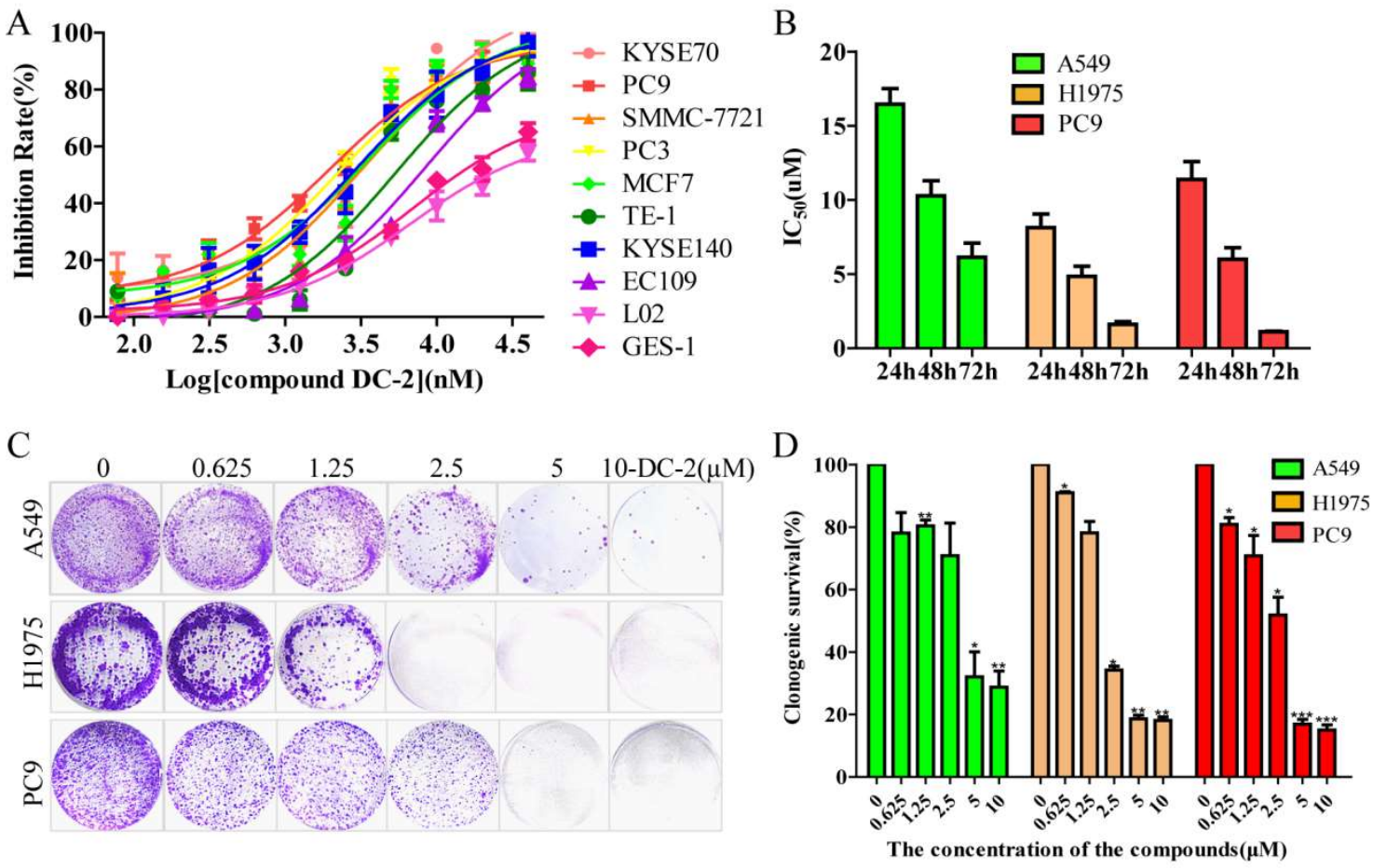

E
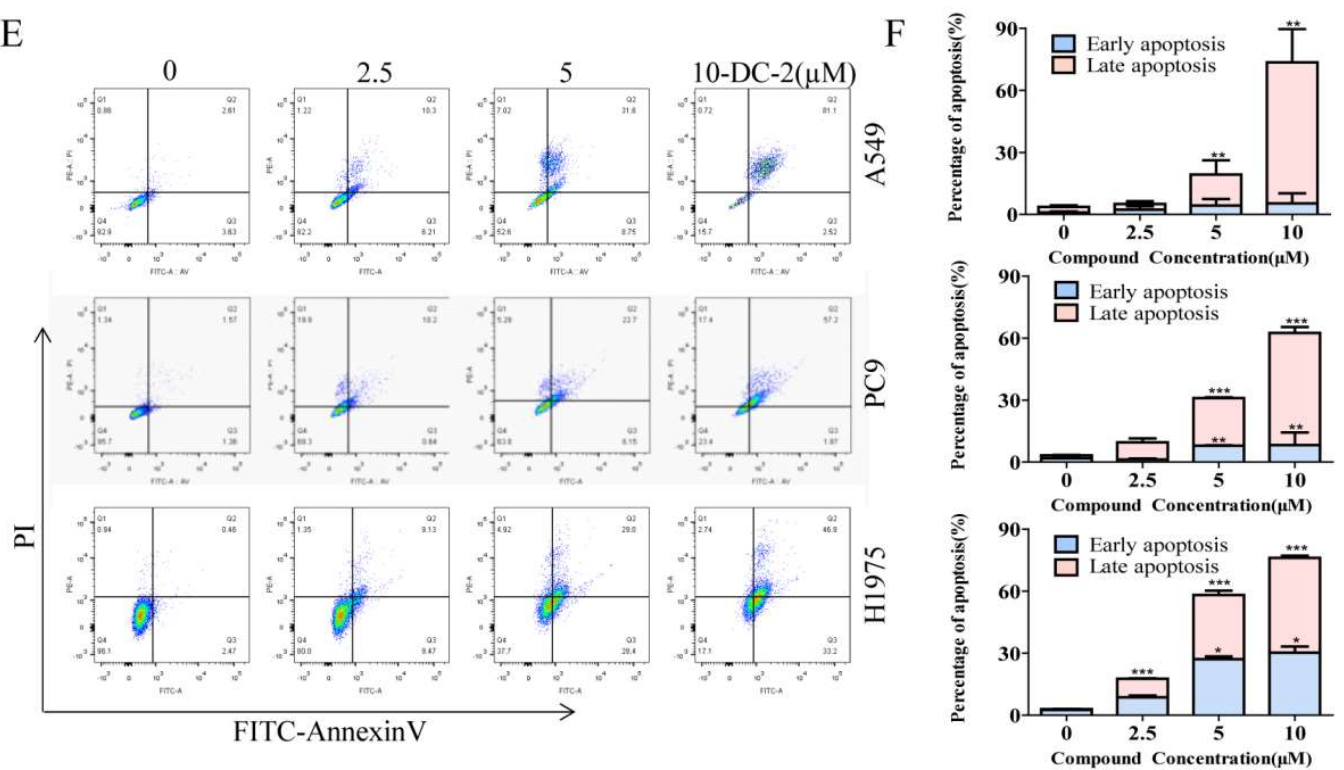

Figure 12. Compound DC-2 inhibits cell proliferation and colony formation. (A) The inhibition rates (\%) of DC-2 on 8 different cancer cell lines and two normal cell lines: L02 and GES-1.

(B) The $\mathrm{IC}_{50}$ values were determined after treating the three lung cancer cell lines (PC9, H1975 and A549) with DC-2 for 24, 48 and 72h. (C) After the treatment of compound DC-2 at 0, $0.625,1.25,2.5,5$ and $10 \mu \mathrm{M}$ for 7 days, cells were stained by crystal violet and then imaged 
by microscopy. (D) Subsequently, they were dissolved and then measured by a BioTek microplate reader. (E and F) The apoptosis were determined by Flow cytometry after PC9, H1975 and A549 cells were treated with compound DC-2 for 48h. Data are presented as means $\pm \mathrm{SD}$. Three individual experiments were performed for each group. $* \mathrm{P}<0.05,{ }^{* *} \mathrm{P}<0.01, * * *$ $\mathrm{P}<0.001$ as compared with the controls.

Effects of DC-2 on DCN1 Highly Expressed Cancer Cells. As DCN1 is highly expressed in most cancers and has been discovered as an oncogene. ${ }^{10,23,33-39,44-46,69}$ In order to determine whether DC-2 has the ability of inhibiting cancer cells' proliferation, eight DCN1 amplified cancer cell lines(KYSE70, PC9, SMMC-7721, PC3, MCF7, TE-1, KYSE140 and EC109) and two normal cell lines (GES-1 and L02) were chosen to be treated with DC-2 for $72 \mathrm{~h}$. As shown in Figure 12A, DC-2 shows strong anti-proliferation ability on these cancer cells rather than normal cells. Furthermore, compound DC-2 could decrease three types of lung cancer cells' viabilities (H1975, PC9 and A549) with time-dependent manner (Figure 12B), block their colony formations (Figure 12C and 12D) and induce their apoptosis dose dependently (Figure 12E and 12F). These results suggest that compound DC-2 has the ability of blocking DCN1 highly expressed cancer cells' proliferation. In addition, the cytotoxicities of DC-2N and the compounds with very similar structures of DC-2N $(27,29,36,37$ and 45$)$ or DC-2 $(33,39,40$, 46 and 47) on five DCN1 highly expressed cancer cells (KYSE70, PC9, SMMC-7721, PC3 and MCF7) were determined. As shown in Table 6, compounds 33, 39, 40, 46 and 47, which can block the DCN1-UBE2M interaction at nanomole level in vitro, also have cytotoxicities on those tested cancer cells with $\mathrm{IC}_{50}$ values ranging from 1 to $12 \mu \mathrm{M}$. However, DC-2N, 27, 29, 
36, 37 and 45, which have no inhibiting effect on DCN1-UBE2M interaction, exhibits less cytotoxic activity $(>20 \mu \mathrm{M})$, indicating that the cytotoxicities of these compounds may be related to their blocking effects on UBE2M-DCN1 interaction. However, the cytotoxic activities of DI-591 on the five DCN1 highly expressed cancer cell lines were also measured. The $\mathrm{IC}_{50}$ values were all above $20 \mu \mathrm{M}$ at $72 \mathrm{~h}$. Based on the current findings, whether DCN1 can be recognized as a valuable anti-tumor target remains to be further investigated. In addition, except the inhibitory effects of DC-2 on DCN1-2, DC-2 also exhibits relatively weak binding affinities on DCN3-5 (Table 5), similar to the findings on NAcM-COV. ${ }^{43}$ Therefore, the cytotoxicities of DC-2 may be also related to its inhibition on DCN3-5. However, the relative less cytotoxicity of DI-591 indicates its higher selectivity on DCN1-2 over DCN3-5. ${ }^{30}$

Table 6. Cytotoxic activities $\left(\mathrm{IC}_{50 \mathrm{~s}}\right)$ of $\mathrm{DC}-2$ and $\mathrm{DC}-2 \mathrm{~N}$ derivatives against five DCN1 highly expressed cancer cell lines ${ }^{a}$.

\begin{tabular}{ccccccc}
\hline \multirow{2}{*}{ Compd. } & \multicolumn{5}{c}{$\mathrm{IC}_{50}(\mu \mathrm{M})^{\mathrm{b}}$} & \multicolumn{2}{c}{ DCN1-UBE2M } \\
\cline { 2 - 7 } & KYSE70 & PC9 & SMMC-7721 & PC3 & MCF7 & IC50(nM)-FP \\
\hline $\mathbf{2 7}$ & $>20$ & $>20$ & $>20$ & $>20$ & $>20$ & $>10000$ \\
$\mathbf{2 9}$ & $>10$ & $>20$ & $>20$ & $>10$ & $>10$ & $>10000$ \\
DC-2N & $>20$ & $>20$ & $>20$ & $>20$ & $>20$ & $>10000$ \\
$\mathbf{3 6}$ & $>20$ & $>20$ & $>20$ & $>20$ & $>20$ & $>10000$ \\
$\mathbf{3 7}$ & $>20$ & $>20$ & $>20$ & $>20$ & $>20$ & $>10000$ \\
$\mathbf{4 5}$ & $>20$ & $>20$ & $>20$ & $>20$ & $>20$ & $>20000$ \\
$\mathbf{3 3}$ & $8.25 \pm 0.91$ & $7.96 \pm 0.90$ & $4.66 \pm 0.66$ & $10.28 \pm 1.01$ & $9.82 \pm 0.99$ & $195.66 \pm 2.29$ \\
$\mathbf{3 9}$ & $5.35 \pm 0.72$ & $4.13 \pm 0.61$ & $6.04 \pm 0.78$ & $3.62 \pm 0.55$ & $3.23 \pm 0.51$ & $36.59 \pm 0.18$ \\
$\mathbf{4 0}$ & $10.88 \pm 1.03$ & $12.11 \pm 1.08$ & $3.99 \pm 0.60$ & $8.53 \pm 0.93$ & $11.63 \pm 1.06$ & $551.87 \pm 1.71$ \\
DC-2 & $4.30 \pm 0.63$ & $1.11 \pm 0.04$ & $2.45 \pm 0.39$ & $1.62 \pm 0.32$ & $2.20 \pm 0.34$ & $26.89 \pm 0.24$ \\
$\mathbf{4 6}$ & $6.56 \pm 0.81$ & $5.30 \pm 0.72$ & $7.34 \pm 0.86$ & $7.17 \pm 0.85$ & $6.18 \pm 0.79$ & $63.51 \pm 1.80$ \\
$\mathbf{4 7}$ & $5.32 \pm 0.72$ & $6.48 \pm 0.81$ & $8.64 \pm 0.93$ & $3.54 \pm 0.55$ & $4.12 \pm 0.61$ & $106.21 \pm 2.02$ \\
$\mathbf{N A c M - C O V}$ & $17.89 \pm 1.25$ & $5.59 \pm 0.74$ & $16.24 \pm 1.21$ & $25.27 \pm 1.40$ & $10.17 \pm 1.00$ & $\mathrm{ND}$ \\
\hline
\end{tabular}

${ }^{\text {a }}$ Cells were treated with different concentrations of the indicated compounds for $72 \mathrm{~h}$. Cell viability was measured by MTT assay as described in the experimental section. 
${ }^{\mathrm{b}} \mathrm{IC}_{50}$ values were indicated as the mean $\pm \mathrm{SD}$ of three independent experiments. ND means the value was not determined.

\section{- CONCLUSIONS}

In this study, a novel series of compounds with a 5-cyano-6-phenylpyrimidin scaffold as DCN1-UBE2M interaction modulators have been identified through structure-based optimization, which enriches the structure types of DCN1 inhibitors. Among the inhibitors, compound DC-2 exhibits the most potent inhibition effect on DCN1-UBE2M interaction at molecule and cellular levels. Molecular docking results show that DC-2 can well dock into the binding pocket of DCN1. Site specific mutations further verified its blocking effects. Furthermore, unlike MLN4924, obliterating all cullins neddylation, DC-2 specifically diminishes the neddylation of cullin3, which leads to the accumulation of cullin3's substrate NRF2 and NRF2's downstream proteins: HO-1 and NQO1. Our findings indicate that the 5cyano-6-phenylpyrimidin based small molecules may serve as leading compounds specifically targeting DCN1-UBE2M interaction.

\section{- EXPERIMENTAL SECTION}

General Methods for Chemistry. Chemicals and solvents were obtained from standard suppliers and used directly without further purification. Melting points were taken on an X-5 micromelting apparatus and were uncorrected. ${ }^{1} \mathrm{H}$ and ${ }^{13} \mathrm{C}$ NMR spectra were respectively determined with a 400 and $100 \mathrm{MHz}$ spectrometer. High resolution mass spectra (HRMS) were obtained with a Water Q-TOF electrospray mass spectrometer (Water, Milford, MA). Final products were of $>95 \%$ purity as analyzed by HPLC analysis (Phenomenex column, C-18, 5.0 $\mu \mathrm{m}, 4.6 \mathrm{~mm} \times 150 \mathrm{~mm}$ ) on Dionex UltiMate 3000 UHPLC instrument from ThermoFisher. Besides, PAINS screening of the synthesized compounds was carried out by employing the 
online program ${ }^{70}$ and all the tested compounds passed the filter.

General Procedure for the Synthesis of Compounds 6-52 and 54. To a well stirred solution of the appropriate mercapto heterocyclics and anilines $(5 \mathrm{mmol})$ in absolute ethanol $(10 \mathrm{~mL})$, equimolar amount of a solution of compounds $\mathbf{5 a - 0}$ or $\mathbf{5 3}(5 \mathrm{mmol})$ in absolute ethanol $(10 \mathrm{~mL})$ was added. The reaction mixture was stirred and heated under reflux for $5 \mathrm{~h}$. Upon completion, the precipitated product was filtered off and washed with ethanol to afford the crude product. The crude product was recrystallized from ethanol to yield the pure product 6$\mathbf{5 2}$ and 54. The detailed information of synthesis and characterization of compounds $\mathbf{5 a - 0}$ and $\mathbf{5 3}$ were reported in published articles. ${ }^{54,71-73}$

4-((1-methyl-1H-tetrazol-5-yl)thio)-6-(2-oxo-2H-chromen-6-yl)-2-(prop-2-yn-1ylthio)pyrimidine-5-carbonitrile (6)

Yield 88.5\%. White solid. Mp: $184-185^{\circ} \mathrm{C} .{ }^{1} \mathrm{H}$ NMR (400 MHz, DMSO- $\left.d_{6}, \mathrm{ppm}\right) \delta 8.36$ $(\mathrm{d}, J=1.7 \mathrm{~Hz}, 1 \mathrm{H}, \mathrm{Ar}-\mathrm{H}), 8.22(\mathrm{dd}, J=6.2,4.0 \mathrm{~Hz}, 2 \mathrm{H}, \mathrm{Ar}-\mathrm{H}), 7.66(\mathrm{~d}, J=14.7 \mathrm{~Hz}, 1 \mathrm{H}, \mathrm{Ar}-$ H), $6.62(\mathrm{~d}, J=9.6 \mathrm{~Hz}, 1 \mathrm{H}, \mathrm{Ar}-\mathrm{H}), 4.14\left(\mathrm{~s}, 3 \mathrm{H},-\mathrm{CH}_{3}\right), 3.57\left(\mathrm{~d}, 2 \mathrm{H},-\mathrm{CH}_{2}-\right), 3.17(\mathrm{~s}, 1 \mathrm{H}, J=2.5$ $\mathrm{Hz}, \equiv \mathrm{C}-\mathrm{H}) .{ }^{13} \mathrm{C}$ NMR $\left(100 \mathrm{MHz}, \mathrm{DMSO}-d_{6}, \mathrm{ppm}\right) \delta 172.31,169.73,165.20,159.34,155.73$, $145.48,143.73,132.19,130.26,129.64,119.06,117.39,117.10,114.61,98.65,78.79,73.56$, 34.79, 19.12. HR-MS (ESI), calcd. $\mathrm{C}_{19} \mathrm{H}_{11} \mathrm{~N}_{7} \mathrm{NaO}_{2} \mathrm{~S}_{2}$, [M+Na] $]^{+} \mathrm{m} / \mathrm{z}: 456.0313$, found: 456.0315 . 4-((1-methyl-1H-tetrazol-5-yl)thio)-2-(prop-2-yn-1-ylthio)-6-(thiophen-3-yl)pyrimidine5-carbonitrile (7)

Yield 83.9\%. White solid. Mp: $183-184^{\circ} \mathrm{C} .{ }^{1} \mathrm{H}$ NMR (400 MHz, DMSO- $\left.d_{6}, \mathrm{ppm}\right) \delta 8.32$ (s, 1H, Ar-H), $8.13(\mathrm{~d}, J=4.1 \mathrm{~Hz}, 1 \mathrm{H}, \mathrm{Ar}-\mathrm{H}), 7.39(\mathrm{~s}, 1 \mathrm{H}, \mathrm{Ar}-\mathrm{H}), 4.11\left(\mathrm{~s}, 3 \mathrm{H},-\mathrm{CH}_{3}\right), 3.59$ (d, $\left.2 \mathrm{H},-\mathrm{CH}_{2}-\right), 3.15(\mathrm{t}, 1 \mathrm{H}, \equiv \mathrm{C}-\mathrm{H}) .{ }^{13} \mathrm{C}$ NMR $\left(100 \mathrm{MHz}, \mathrm{DMSO}-d_{6}, \mathrm{ppm}\right) \delta 171.87,169.80,158.29$, $145.45,138.13,135.80,132.60,129.72,114.96,94.27,78.77,73.52,34.75,19.06$. HR-MS (ESI), calcd. $\mathrm{C}_{14} \mathrm{H}_{9} \mathrm{~N}_{7} \mathrm{NaS}_{3}$, [M+Na $]^{+}$m/z: 393.9979, found: 393.9982 .

4-(1H-indol-3-yl)-6-((1-methyl-1H-tetrazol-5-yl)thio)-2-(prop-2-yn-1-ylthio)pyrimidine5-carbonitrile (8)

Yield 86.6\%. White solid. Mp: $227-227^{\circ} \mathrm{C} .{ }^{1} \mathrm{H}$ NMR (400 MHz, DMSO- $\left.d_{6}, \mathrm{ppm}\right) \delta 12.37$ (s, 1H, NH, $\mathrm{D}_{2} \mathrm{O}$ exchangeable), $8.63(\mathrm{~d}, \mathrm{~J}=3.0 \mathrm{~Hz}, 1 \mathrm{H},-\mathrm{CH}=), 8.41(\mathrm{~d}, \mathrm{~J}=7.8 \mathrm{~Hz}, 1 \mathrm{H}, \mathrm{Ar}-$ 
H), $7.57(\mathrm{~d}, \mathrm{~J}=7.9 \mathrm{~Hz}, 1 \mathrm{H}, \mathrm{Ar}-\mathrm{H}), 7.29$ (t, J = 7.3 Hz, 1H, Ar-H), 7.24 (t, J = 7.5 Hz, 1H, Ar-

$\mathrm{H}), 4.13\left(\mathrm{~s}, 3 \mathrm{H},-\mathrm{CH}_{3}\right), 3.59\left(\mathrm{~d}, \mathrm{~J}=2.3 \mathrm{~Hz}, 2 \mathrm{H},-\mathrm{CH}_{2}-\right), 3.17(\mathrm{t}, \mathrm{J}=2.4 \mathrm{~Hz}, 1 \mathrm{H}, \equiv \mathrm{C}-\mathrm{H}) .{ }^{13} \mathrm{C}$ NMR (100 MHz, DMSO- $\left.d_{6}, \mathrm{ppm}\right) \delta 171.68,168.60,161.76,136.52,132.66,125.44,123.43$, 122.29, 122.06, 116.14, 112.60, 110.30, 93.65, 79.15, 73.57, 34.75, 18.78. HR-MS (ESI), calcd. $\mathrm{C}_{18} \mathrm{H}_{12} \mathrm{~N}_{8} \mathrm{NaS}_{2},[\mathrm{M}+\mathrm{Na}]^{+} \mathrm{m} / \mathrm{z}: 427.0524$, found: 427.0525 .

4-((1-methyl-1H-tetrazol-5-yl)thio)-2-(prop-2-yn-1-ylthio)-6-(1H-pyrrol-2-yl)pyrimidine5-carbonitrile (9)

Yield 51.6\%. White solid. Mp: $189-190^{\circ} \mathrm{C} .{ }^{1} \mathrm{H}$ NMR (400 MHz, DMSO- $\left.d_{6}, \mathrm{ppm}\right) \delta 12.08$ (s, 1H, NH, $\mathrm{D}_{2} \mathrm{O}$ exchangeable), $7.49(\mathrm{~s}, 1 \mathrm{H},-\mathrm{CH}=), 7.29(\mathrm{~s}, 1 \mathrm{H},-\mathrm{CH}=), 6.53-6.32(\mathrm{~m}, 1 \mathrm{H},-$ $\mathrm{CH}=), 4.10\left(\mathrm{~s}, 3 \mathrm{H},-\mathrm{CH}_{3}\right), 3.69\left(\mathrm{~d}, J=2.6 \mathrm{~Hz}, 2 \mathrm{H},-\mathrm{CH}_{2}-\right), 3.15(\mathrm{t}, J=2.5 \mathrm{~Hz}, 1 \mathrm{H}, \equiv \mathrm{C}-\mathrm{H}) .{ }^{13} \mathrm{C}$ NMR (100 MHz, DMSO- $d_{6}$, ppm) $\delta 171.53,168.77,155.43,145.62,127.32,125.45,117.04$, 115.44, 112.13, 91.76, 79.03, 73.67, 34.72, 18.86. HR-MS (ESI), calcd. $\mathrm{C}_{14} \mathrm{H}_{10} \mathrm{~N}_{8} \mathrm{NaS}_{2}$, $[\mathrm{M}+\mathrm{Na}]^{+} \mathrm{m} / \mathrm{z}: 418.0521$, found: 418.0521

4-((1-methyl-1H-tetrazol-5-yl)thio)-2-(prop-2-yn-1-ylthio)-6-(3,4,5trimethoxyphenyl)pyrimidine-5-carbonitrile (10)

Yield $82.1 \%$. White solid. Mp: $256-256^{\circ} \mathrm{C} .{ }^{1} \mathrm{H}$ NMR (400 MHz, DMSO- $\left.d_{6}, \mathrm{ppm}\right) \delta 7.40$ (s, 2H, Ar-H), $4.12\left(\mathrm{~s}, 3 \mathrm{H},-\mathrm{CH}_{3}\right), 3.87\left(\mathrm{~s}, 6 \mathrm{H},-\mathrm{CH}_{3}\right), 3.80\left(\mathrm{~s}, 3 \mathrm{H},-\mathrm{CH}_{3}\right), 3.65$ (t, J = $12.7 \mathrm{~Hz}$, $\left.2 \mathrm{H},-\mathrm{CH}_{2}-\right), 3.20(\mathrm{t}, \mathrm{J}=2.3 \mathrm{~Hz}, 1 \mathrm{H}, \equiv \mathrm{C}-\mathrm{H}) .{ }^{13} \mathrm{C} \mathrm{NMR}\left(100 \mathrm{MHz}, \mathrm{DMSO}-d_{6}, \mathrm{ppm}\right) \delta 172.55$, $170.08,166.35,153.39,146.06,141.54,129.54,115.48,107.34,98.83,79.69,73.84,60.78$, 56.69, 35.24, 19.77. HR-MS (ESI), calcd. $\mathrm{C}_{19} \mathrm{H}_{17} \mathrm{~N}_{7} \mathrm{NaO}_{3} \mathrm{~S}_{2}$, [M+Na] $]^{+} \mathrm{m} / \mathrm{z}: 478.0732$, found: 478.0733 .

4-(4-chlorophenyl)-6-((1-methyl-1H-tetrazol-5-yl)thio)-2-(prop-2-yn-1ylthio)pyrimidine-5-carbonitrile (11)

Yield $87.7 \%$. White solid. Mp: $163-164^{\circ} \mathrm{C} .{ }^{1} \mathrm{H}$ NMR (400 MHz, DMSO- $\left.d_{6}, \mathrm{ppm}\right) \delta 8.02$ (d, $J=8.4 \mathrm{~Hz}, 2 \mathrm{H}, \mathrm{Ar}-\mathrm{H}), 7.74(\mathrm{t}, J=19.1 \mathrm{~Hz}, 2 \mathrm{H}, \mathrm{Ar}-\mathrm{H}), 4.13$ (s, 3H, - $\left.\mathrm{CH}_{3}\right), 3.59$ (s, 2H, $\left.\mathrm{CH}_{2}-\right), 3.15(\mathrm{~s}, J=2.5 \mathrm{~Hz}, 1 \mathrm{H}, \equiv \mathrm{C}-\mathrm{H}) .{ }^{13} \mathrm{C}$ NMR $\left(100 \mathrm{MHz}, \mathrm{DMSO}-d_{6}, \mathrm{ppm}\right) \delta 172.30,169.69$, $165.47,145.47,137.36,132.92,130.85,129.06,114.55,98.72,78.78,73.51,34.78,19.10$. HRMS (ESI), calcd. $\mathrm{C}_{16} \mathrm{H}_{10} \mathrm{ClN}_{7} \mathrm{~S}_{2},[\mathrm{M}+\mathrm{Na}]^{+} \mathrm{m} / \mathrm{z}: 422.0025$, found: 422.0025 . 
4-(3-chlorophenyl)-6-((1-methyl-1H-tetrazol-5-yl)thio)-2-(prop-2-yn-1-

ylthio)pyrimidine-5-carbonitrile (12)

Yield $89.7 \%$. White solid. Mp: $163-165^{\circ} \mathrm{C} .{ }^{1} \mathrm{H}$ NMR (400 MHz, DMSO- $\left.d_{6}, \mathrm{ppm}\right) \delta 8.00$ (t, $J=1.8 \mathrm{~Hz}, 1 \mathrm{H}, \mathrm{Ar}-\mathrm{H}), 7.94(\mathrm{~d}, J=7.8 \mathrm{~Hz}, 1 \mathrm{H}, \mathrm{Ar}-\mathrm{H}), 7.78-7.73$ (m, 1H, Ar-H), 7.67 (t, $J$ $=7.9 \mathrm{~Hz}, 1 \mathrm{H}, \mathrm{Ar}-\mathrm{H}), 4.13\left(\mathrm{~s}, 3 \mathrm{H},-\mathrm{CH}_{3}\right), 3.60\left(\mathrm{~d}, J=7.5 \mathrm{~Hz}, 2 \mathrm{H},-\mathrm{CH}_{2}-\right), 3.16(\mathrm{t}, J=2.5 \mathrm{~Hz}$, $1 \mathrm{H}, \equiv \mathrm{C}-\mathrm{H}) .{ }^{13} \mathrm{C}$ NMR $\left(100 \mathrm{MHz}, \mathrm{DMSO}-d_{6}, \mathrm{ppm}\right) \delta 172.39,169.63,165.23,145.46,136.11$, $133.55,131.96,130.87,128.65,127.65,114.43,99.11,78.81,73.46,34.77,19.12$. HR-MS (ESI), calcd. $\mathrm{C}_{16} \mathrm{H}_{10} \mathrm{ClN}_{7} \mathrm{NaS}_{2},[\mathrm{M}+\mathrm{Na}]^{+} \mathrm{m} / \mathrm{z}: 422.0025$, found: 422.0025 .

4-(4-bromophenyl)-6-((1-methyl-1H-tetrazol-5-yl)thio)-2-(prop-2-yn-1ylthio)pyrimidine-5-carbonitrile (13)

Yield 78.1\%. Yellow solid. Mp: $238-239^{\circ} \mathrm{C} .{ }^{1} \mathrm{H}$ NMR (400 MHz, DMSO- $\left.d_{6}, \mathrm{ppm}\right) \delta 8.23$ (d, $J=3.3 \mathrm{~Hz}, 1 \mathrm{H},-\mathrm{CH}=), 8.13(\mathrm{~d}, J=3.3 \mathrm{~Hz}, 1 \mathrm{H},-\mathrm{CH}=), 7.97-7.91$ (m, 2H, Ar-H), $7.88-$ $7.82(\mathrm{~m}, 2 \mathrm{H}, \mathrm{Ar}-\mathrm{H}), 3.79\left(\mathrm{~d}, J=2.6 \mathrm{~Hz}, 2 \mathrm{H},-\mathrm{CH}_{2}-\right), 3.14(\mathrm{t}, J=2.6 \mathrm{~Hz}, 1 \mathrm{H}, \equiv \mathrm{C}-\mathrm{H}) .{ }^{13} \mathrm{C}$ NMR (100 MHz, DMSO- $d_{6}$, ppm) $\delta 172.03,171.48,165.43,150.29,144.31,133.50,131.91,131.04$, 127.91, 126.18, 114.45, 98.20, 79.06, 73.86, 19.29. HR-MS (ESI), calcd. $\mathrm{C}_{16} \mathrm{H}_{10} \mathrm{BrN}_{7} \mathrm{NaS}_{2}$, $[\mathrm{M}+\mathrm{Na}]^{+} \mathrm{m} / \mathrm{z}: 466.9070$, found: 466.9073

4-((1-methyl-1H-tetrazol-5-yl)thio)-2-(prop-2-yn-1-ylthio)-6-(p-tolyl)pyrimidine-5carbonitrile (14)

Yield 83.1\%. Yellow solid. Mp: $164-165^{\circ} \mathrm{C} .{ }^{1} \mathrm{H}$ NMR (400 MHz, DMSO-d 6, ppm) $\delta 7.92$ (d, $J=8.2 \mathrm{~Hz}, 2 \mathrm{H}, \mathrm{Ar}-\mathrm{H}), 7.44(\mathrm{~d}, J=8.1 \mathrm{~Hz}, 2 \mathrm{H}, \mathrm{Ar}-\mathrm{H}), 4.13\left(\mathrm{~s}, 3 \mathrm{H},-\mathrm{CH}_{3}\right), 3.56(\mathrm{t}, J=20.3$ $\left.\mathrm{Hz}, 2 \mathrm{H},-\mathrm{CH}_{2}-\right), 3.15(\mathrm{t}, J=2.5 \mathrm{~Hz}, 1 \mathrm{H}, \equiv \mathrm{C}-\mathrm{H}), 2.42\left(\mathrm{~s}, 3 \mathrm{H},-\mathrm{CH}_{3}\right) \cdot{ }^{13} \mathrm{C}$ NMR $(100 \mathrm{MHz}$, DMSO- $\left.d_{6}, \mathrm{ppm}\right) \delta 172.13,169.62,166.39,145.54,142.88,131.32,129.49,129.01,114.82$, 98.19, 78.87, 73.46, 34.76, 21.09, 19.05. HR-MS (ESI), calcd. $\mathrm{C}_{17} \mathrm{H}_{13} \mathrm{~N}_{7} \mathrm{NaS}_{2},[\mathrm{M}+\mathrm{Na}]^{+} \mathrm{m} / \mathrm{z}$ : 402.0572, found: 402.0573 .

5-(4-isopropylphenyl)-6-((1-methyl-1H-tetrazol-5-yl)thio)-2-(prop-2-yn-1ylthio)pyrimidine-5-carbonitrile (15)

Yield 83.4\%. White solid. Mp: $141-142^{\circ} \mathrm{C} .{ }^{1} \mathrm{H}$ NMR (400 MHz, DMSO- $\left.d_{6}, \mathrm{ppm}\right) \delta 7.95$ $(\mathrm{d}, J=3.9 \mathrm{~Hz}, 2 \mathrm{H}, \mathrm{Ar}-\mathrm{H}), 7.50(\mathrm{~d}, J=8.0 \mathrm{~Hz}, 2 \mathrm{H}, \mathrm{Ar}-\mathrm{H}), 4.14\left(\mathrm{~d}, J=4.0 \mathrm{~Hz}, 3 \mathrm{H},-\mathrm{CH}_{3}\right), 3.60$ 
(s, 2H, $\left.-\mathrm{CH}_{2^{-}}\right), 3.15(\mathrm{t}, J=2.5 \mathrm{~Hz}, 1 \mathrm{H}, \equiv \mathrm{C}-\mathrm{H}), 3.05-2.96(\mathrm{~m}, 1 \mathrm{H},-\mathrm{CH}), 1.25(\mathrm{~d}, J=6.8 \mathrm{~Hz}$, $\left.6 \mathrm{H},-\mathrm{CH}_{3}\right) .{ }^{13} \mathrm{C}$ NMR $\left(100 \mathrm{MHz}, \mathrm{DMSO}-d_{6}, \mathrm{ppm}\right) \delta 172.16,169.65,166.36,153.39,145.54$, 131.70, 129.19, 126.92, 114.85, 98.17, 78.89, 73.46, 34.77, 33.47, 23.47, 19.06. HR-MS (ESI), calcd. $\mathrm{C}_{19} \mathrm{H}_{17} \mathrm{~N}_{7} \mathrm{NaS}_{2},[\mathrm{M}+\mathrm{Na}]^{+} \mathrm{m} / \mathrm{z}: 430.0885$, found: 430.0886 .

4-(3-methoxyphenyl)-6-((1-methyl-1H-tetrazol-5-yl)thio)-2-(prop-2-yn-1ylthio)pyrimidine-5-carbonitrile (16)

Yield 89.9\%. White solid. Mp: $189-192^{\circ} \mathrm{C} .{ }^{1} \mathrm{H}$ NMR (400 MHz, DMSO- $\left.d_{6}, \mathrm{ppm}\right) \delta 7.56$ (s, 1H, Ar-H), 7.54 (d, $J=3.7 \mathrm{~Hz}, 2 \mathrm{H}, \mathrm{Ar}-\mathrm{H}), 7.25(\mathrm{dt}, J=6.9,2.2 \mathrm{~Hz}, 1 \mathrm{H}, \mathrm{Ar}-\mathrm{H}), 4.12(\mathrm{~s}, 3 \mathrm{H}$, $\left.-\mathrm{CH}_{3}\right), 3.84\left(\mathrm{~s}, 3 \mathrm{H},-\mathrm{CH}_{3}\right), 3.61\left(\mathrm{~d}, J=2.4 \mathrm{~Hz}, 2 \mathrm{H},-\mathrm{CH}_{2}-\right), 3.17(\mathrm{t}, J=2.5 \mathrm{~Hz}, 1 \mathrm{H}, \equiv \mathrm{C}-\mathrm{H}) .{ }^{13} \mathrm{C}$ NMR (100 MHz, DMSO- $\left.d_{6}, \mathrm{ppm}\right) \delta 172.22,169.63,166.35,159.27,145.52,135.41,130.15$, 121.20, 118.09, 114.67, 114.17, 98.78, 78.95, 73.42, 55.43, 34.76, 19.11. HR-MS (ESI), calcd. $\mathrm{C}_{17} \mathrm{H}_{13} \mathrm{~N}_{7} \mathrm{ONaS}$, $[\mathrm{M}+\mathrm{Na}]^{+} \mathrm{m} / \mathrm{z}:$ 418.0521, found: 418.0521 .

\section{4-(3,4-dichlorophenyl)-6-((1-methyl-1H-tetrazol-5-yl)thio)-2-(prop-2-yn-1-} ylthio)pyrimidine-5-carbonitrile (17)

Yield $89.8 \%$. White solid. Mp: $151-152^{\circ} \mathrm{C} .{ }^{1} \mathrm{H}$ NMR (400 MHz, DMSO- $\left.d_{6}, \mathrm{ppm}\right) \delta 8.21$ (d, $J=1.8 \mathrm{~Hz}, 1 \mathrm{H}, \mathrm{Ar}-\mathrm{H}), 7.97$ (dd, $J=8.4,1.9 \mathrm{~Hz}, 1 \mathrm{H}, \mathrm{Ar}-\mathrm{H}), 7.93$ (d, $J=8.4 \mathrm{~Hz}, 1 \mathrm{H}, \mathrm{Ar}-\mathrm{H})$, $4.13\left(\mathrm{~s}, 3 \mathrm{H},-\mathrm{CH}_{3}\right), 3.61\left(\mathrm{~d}, J=2.3 \mathrm{~Hz}, 2 \mathrm{H},-\mathrm{CH}_{2}-\right), 3.16(\mathrm{t}, J=2.4 \mathrm{~Hz}, 1 \mathrm{H}, \equiv \mathrm{C}-\mathrm{H}) .{ }^{13} \mathrm{C}$ NMR (100 MHz, DMSO- $\left.d_{6}, \mathrm{ppm}\right) \delta 172.45,169.65,164.28,145.42,135.21,134.56,131.82,131.26$, 130.80, 129.05, 114.32, 99.14, 78.77, 73.52, 34.78, 19.18. HR-MS (ESI), calcd. $\mathrm{C}_{16} \mathrm{H}_{9} \mathrm{Cl}_{2} \mathrm{~N}_{7} \mathrm{NaS}_{2},[\mathrm{M}+\mathrm{Na}]^{+} \mathrm{m} / \mathrm{z}: 455.9636$, found: 455.9637.

\section{4-((1-methyl-1H-tetrazol-5-yl)thio)-6-phenyl-2-(prop-2-yn-1-ylthio)pyrimidine-5-} carbonitrile (18)

Yield $81.9 \%$. White solid. Mp: $130-131^{\circ} \mathrm{C} .{ }^{1} \mathrm{H}$ NMR (400 MHz, DMSO- $\left.d_{6}, \mathrm{ppm}\right) \delta 8.17$ (d, $J=7.5 \mathrm{~Hz}, 2 \mathrm{H}, \mathrm{Ar}-\mathrm{H}), 8.07$ (s, 1H, Ar-H), $7.59-7.55$ (m, 2H, Ar-H), 4.10 (s, 3H, - $\left.\mathrm{CH}_{3}\right)$, $3.67\left(\mathrm{~d}, 2 \mathrm{H},-\mathrm{CH}_{2}-\right), 3.11(\mathrm{t}, J=2.5 \mathrm{~Hz}, 1 \mathrm{H}, \equiv \mathrm{C}-\mathrm{H}) .{ }^{13} \mathrm{C}$ NMR $\left(100 \mathrm{MHz}\right.$, DMSO- $\left.d_{6}, \mathrm{ppm}\right) \delta$ $172.30,169.69,165.47,145.47,137.36,132.92,130.85,129.06,114.55,98.72,78.78,73.51$, 34.78, 19.10. HR-MS (ESI), calcd. $\mathrm{C}_{16} \mathrm{H}_{11} \mathrm{~N}_{7} \mathrm{NaS}_{2},[\mathrm{M}+\mathrm{Na}]^{+} \mathrm{m} / \mathrm{z}: 388.0415$, found: 388.0415 . 
4-((1-methyl-1H-tetrazol-5-yl)amino)-2-(prop-2-yn-1-ylthio)-6-(3,4,5-

trimethoxyphenyl)pyrimidine-5-carbonitrile (19)

Yield 94.1\%. Yellow solid. Mp: $205-206^{\circ} \mathrm{C} .{ }^{1} \mathrm{H}$ NMR (400 MHz, DMSO- $\left.d_{6}, \mathrm{ppm}\right) \delta 7.38$ (s, 2H, Ar-H), 3.93 (s, 3H, - $\left.\mathrm{CH}_{3}\right), 3.87\left(\mathrm{~s}, 6 \mathrm{H},-\mathrm{CH}_{3}\right), 3.85$ (d, J=1.8 Hz, 2H, - $\left.\mathrm{CH}_{2}-\right), 3.78$ (s, $\left.3 \mathrm{H},-\mathrm{CH}_{3}\right), 3.16(\mathrm{t}, J=2.5 \mathrm{~Hz}, 1 \mathrm{H}, \equiv \mathrm{C}-\mathrm{H}) .{ }^{13} \mathrm{C} \mathrm{NMR}\left(100 \mathrm{MHz}, \mathrm{DMSO}-d_{6}, \mathrm{ppm}\right) \delta 171.96$, $167.33,161.41,152.71,150.04,140.43,130.11,115.42,106.68,86.40,79.95,72.99,60.22$, 56.11, 33.61, 19.17. HR-MS (ESI), calcd. $\mathrm{C}_{19} \mathrm{H}_{18} \mathrm{~N}_{8} \mathrm{NaO}_{3} \mathrm{~S}$, $[\mathrm{M}+\mathrm{Na}]^{+} \mathrm{m} / \mathrm{z}: 461.1120$, found: 461.1122.

4-(piperazin-1-yl)-2-(prop-2-yn-1-ylthio)-6-(3,4,5-trimethoxyphenyl)pyrimidine-5carbonitrile (20)

Yield 89.0\%. White solid. Mp: $242-243^{\circ} \mathrm{C} .{ }^{1} \mathrm{H}$ NMR (400 MHz, DMSO- $\left.d_{6}, \mathrm{ppm}\right) \delta 9.72$ (s, 1H, NH, $\mathrm{D}_{2} \mathrm{O}$ exchangeable), $7.30(\mathrm{~s}, 2 \mathrm{H}, \mathrm{Ar}-\mathrm{H}), 4.19\left(\mathrm{~s}, 4 \mathrm{H},-\mathrm{CH}_{2}-\right), 4.03(\mathrm{~d}, J=2.1 \mathrm{~Hz}$, $\left.2 \mathrm{H},-\mathrm{CH}_{2}-\right), 3.86\left(\mathrm{~s}, 6 \mathrm{H},-\mathrm{CH}_{3}\right), 3.77\left(\mathrm{~s}, 3 \mathrm{H},-\mathrm{CH}_{3}\right), 3.34$ (s, $\left.4 \mathrm{H},-\mathrm{CH}_{2}-\right), 3.21$ (t, J=2.3 Hz, $1 \mathrm{H}$, $\equiv \mathrm{C}-\mathrm{H}) .{ }^{13} \mathrm{C}$ NMR $\left(100 \mathrm{MHz}, \mathrm{DMSO}-d_{6}, \mathrm{ppm}\right) \delta 170.58,169.15,161.75,152.60,140.23,130.88$, 117.90, 107.18, 83.78, 80.45, 73.00, 60.18, 56.16, 45.75, 19.26. HR-MS (ESI), calcd. $\mathrm{C}_{21} \mathrm{H}_{24} \mathrm{~N}_{5} \mathrm{O}_{3} \mathrm{~S},[\mathrm{M}+\mathrm{H}]^{+} \mathrm{m} / \mathrm{z}: 426.1600$, found: 426.1602 .

2-(prop-2-yn-1-ylthio)-4-thiomorpholino-6-(3,4,5-trimethoxyphenyl)pyrimidine-5carbonitrile (21)

Yield 50.9\%. Yellow solid. Mp: $152-153^{\circ} \mathrm{C} .{ }^{1} \mathrm{H}$ NMR (400 MHz, DMSO- $\left.d_{6}, \mathrm{ppm}\right) \delta 7.28$ (s, 2H, Ar-H), 4.19 (m, 4H, - $\left.\mathrm{CH}_{2}-\right), 3.98$ (d, J=2.4 Hz, 2H, - $\left.\mathrm{CH}_{2}-\right), 3.85\left(\mathrm{~s}, 6 \mathrm{H},-\mathrm{CH}_{3}\right), 3.77$ (s, $\left.3 \mathrm{H},-\mathrm{CH}_{3}\right), 3.19(\mathrm{t}, J=2.3 \mathrm{~Hz}, 1 \mathrm{H}, \equiv \mathrm{C}-\mathrm{H}), 2.86-2.77\left(\mathrm{~m}, 4 \mathrm{H},-\mathrm{CH}_{2}-\right) .{ }^{13} \mathrm{C}$ NMR $(100 \mathrm{MHz}$, DMSO- $d_{6}$, ppm) $\delta 170.71,169.42,161.97,152.56,140.21,130.93,117.92,107.23,84.24$, 80.46, 72.89, 60.17, 56.17, 49.70, 26.50, 19.22. HR-MS (ESI), calcd. $\mathrm{C}_{21} \mathrm{H}_{22} \mathrm{~N}_{4} \mathrm{O}_{3} \mathrm{NaS}_{2}$, $[\mathrm{M}+\mathrm{Na}]^{+} \mathrm{m} / \mathrm{z}: 465.1031$, found: 465.1032 .

4-morpholino-2-(prop-2-yn-1-ylthio)-6-(3,4,5-trimethoxyphenyl)pyrimidine-5carbonitrile (22) 
Yield $89.5 \%$. White solid. Mp: $163-164^{\circ} \mathrm{C} .{ }^{1} \mathrm{H}$ NMR (400 MHz, DMSO- $\left.d_{6}, \mathrm{ppm}\right) \delta 7.27$ (s, 2H, Ar-H), $3.98\left(\mathrm{~d}, J=2.5 \mathrm{~Hz}, 2 \mathrm{H},-\mathrm{CH}_{2}-\right), 3.97-3.93\left(\mathrm{~m}, 4 \mathrm{H},-\mathrm{CH}_{2}-\right), 3.85\left(\mathrm{~s}, 6 \mathrm{H},-\mathrm{CH}_{3}\right)$, $3.76\left(\mathrm{~s}, 3 \mathrm{H},-\mathrm{CH}_{3}\right), 3.74\left(\mathrm{~m}, 4 \mathrm{H},-\mathrm{CH}_{2}-\right), 3.19(\mathrm{t}, J=2.5 \mathrm{~Hz}, 1 \mathrm{H}, \equiv \mathrm{C}-\mathrm{H}) .{ }^{13} \mathrm{C}$ NMR $(100 \mathrm{MHz}$, DMSO- $\left.d_{6}, \mathrm{ppm}\right) \delta 170.70,169.34,161.84,152.58,140.24,130.87,117.86,107.20,83.94$, 80.40, 72.91, 65.91, 60.17, 56.16, 47.17, 19.23. HR-MS (ESI), calcd. $\mathrm{C}_{21} \mathrm{H}_{23} \mathrm{~N}_{4} \mathrm{O}_{4} \mathrm{~S},[\mathrm{M}+\mathrm{H}]^{+}$ m/z: 427.1440, found: 427.1441 .

\section{4-(piperidin-1-yl)-2-(prop-2-yn-1-ylthio)-6-(3,4,5-trimethoxyphenyl)pyrimidine-5-} carbonitrile (23)

Yield 90.0\%. White solid. Mp: $120-121^{\circ} \mathrm{C} .{ }^{1} \mathrm{H}$ NMR (400 MHz, DMSO- $\left.d_{6}, \mathrm{ppm}\right) \delta 7.27$ (s, 2H, Ar-H), 3.97 (d, J=2.5 Hz, 2H, - $\left.\mathrm{CH}_{2}-\right), 3.90\left(\mathrm{~m}, 4 \mathrm{H},-\mathrm{CH}_{2}-\right), 3.86\left(\mathrm{~s}, 6 \mathrm{H},-\mathrm{CH}_{3}\right), 3.77(\mathrm{~s}$, $\left.3 \mathrm{H},-\mathrm{CH}_{3}\right), 3.17(\mathrm{t}, J=2.5 \mathrm{~Hz}, 1 \mathrm{H}, \equiv \mathrm{C}-\mathrm{H}), 1.68\left(\mathrm{~s}, 6 \mathrm{H},-\mathrm{CH}_{2}-\right) .{ }^{13} \mathrm{C}$ NMR $(100 \mathrm{MHz}$, DMSO$\left.d_{6}, \mathrm{ppm}\right) \delta 170.55,169.37,161.46,152.54,140.16,131.04,118.01,107.19,83.42,80.48,72.81$, 60.15, 56.16, 47.99, 25.58, 23.64, 19.16. HR-MS (ESI), calcd. $\mathrm{C}_{22} \mathrm{H}_{25} \mathrm{~N}_{4} \mathrm{O}_{3} \mathrm{~S},[\mathrm{M}+\mathrm{H}]^{+} \mathrm{m} / \mathrm{z}$ : 425.1647, found: 425.1648 .

4-((1-(2-(dimethylamino)ethyl)-1H-tetrazol-5-yl)thio)-2-(prop-2-yn-1-ylthio)-6-(3,4,5trimethoxyphenyl)pyrimidine-5-carbonitrile (26)

Yield 75.9\%. Yellow solid. Mp: $197-198^{\circ} \mathrm{C} .{ }^{1} \mathrm{H}$ NMR (400 MHz, DMSO-d 6 , ppm) $\delta 7.42$ (s, 2H, Ar-H), 4.99 (t, $\left.J=6.6 \mathrm{~Hz}, 2 \mathrm{H},-\mathrm{CH}_{2}-\right), 3.87\left(\mathrm{~s}, 6 \mathrm{H},-\mathrm{CH}_{3}\right), 3.79\left(\mathrm{~s}, 3 \mathrm{H},-\mathrm{CH}_{3}\right), 3.72(\mathrm{~d}$, $\left.J=2.3 \mathrm{~Hz}, 2 \mathrm{H},-\mathrm{CH}_{2}-\right), 3.69\left(\mathrm{t}, J=6.6 \mathrm{~Hz}, 2 \mathrm{H},-\mathrm{CH}_{2}-\right), 3.25(\mathrm{t}, J=2.5 \mathrm{~Hz}, 1 \mathrm{H}, \equiv \mathrm{C}-\mathrm{H}), 2.83(\mathrm{~s}$, $\left.6 \mathrm{H},-\mathrm{CH}_{3}\right) .{ }^{13} \mathrm{C}$ NMR $\left(100 \mathrm{MHz}, \mathrm{DMSO}-d_{6}, \mathrm{ppm}\right) \delta 171.96,169.87,165.62,152.90,146.30$, 141.06, 129.01, 115.03, 106.80, 98.30, 79.26, 73.45, 60.29, 56.19, 54.14, 42.69, 42.38, 19.36. HR-MS (ESI), calcd. $\mathrm{C}_{22} \mathrm{H}_{25} \mathrm{~N}_{8} \mathrm{O}_{3} \mathrm{~S}_{2},[\mathrm{M}+\mathrm{H}]^{+} \mathrm{m} / \mathrm{z}$ : 513.1491, found: 513.1491.

4-((1H-1,2,4-triazol-3-yl)thio)-2-(prop-2-yn-1-ylthio)-6-(3,4,5-

trimethoxyphenyl)pyrimidine-5-carbonitrile (27)

Yield $80.9 \%$. White solid. Mp: $234-235^{\circ} \mathrm{C} .{ }^{1} \mathrm{H}$ NMR (400 MHz, DMSO- $\left.d_{6}, \mathrm{ppm}\right) \delta 8.85$ (s, $1 \mathrm{H}, \mathrm{NH}, \mathrm{D}_{2} \mathrm{O}$ exchangeable), $7.41(\mathrm{~s}, 2 \mathrm{H}, \mathrm{Ar}-\mathrm{H}), 3.87\left(\mathrm{~s}, 6 \mathrm{H},-\mathrm{CH}_{3}\right), 3.79\left(\mathrm{~s}, 3 \mathrm{H},-\mathrm{CH}_{3}\right), 3.78$ $-3.78\left(\mathrm{~s}, 2 \mathrm{H},-\mathrm{CH}_{2}-\right), 3.15(\mathrm{t}, J=2.4 \mathrm{~Hz}, 1 \mathrm{H}, \equiv \mathrm{C}-\mathrm{H}) .{ }^{13} \mathrm{C}$ NMR $\left(100 \mathrm{MHz}, \mathrm{DMSO}-d_{6}, \mathrm{ppm}\right) \delta$ $172.22,169.63,166.35,159.27,145.52,135.41,130.15,121.20,118.09,114.67,114.17,98.78$, 
78.95, 73.42, 55.43, 34.76, 19.11. HR-MS (ESI), calcd. $\mathrm{C}_{19} \mathrm{H}_{16} \mathrm{~N}_{6} \mathrm{NaO}_{3} \mathrm{~S}_{2},[\mathrm{M}+\mathrm{Na}]^{+} \mathrm{m} / \mathrm{z}$ : 463.0623, found: 463.0622 .

4-((1-methyl-1H-imidazol-2-yl)thio)-2-(prop-2-yn-1-ylthio)-6-(3,4,5-

trimethoxyphenyl)pyrimidine-5-carbonitrile (28)

Yield $32.8 \%$. White solid. Mp: $176-177^{\circ} \mathrm{C} .{ }^{1} \mathrm{H}$ NMR (400 MHz, DMSO- $\left.d_{6}, \mathrm{ppm}\right) \delta 7.62$ (s, $1 \mathrm{H},-\mathrm{CH}=), 7.38(\mathrm{~s}, 2 \mathrm{H}, \mathrm{Ar}-\mathrm{H}), 7.22(\mathrm{~s}, 1 \mathrm{H},-\mathrm{CH}=), 3.87\left(\mathrm{~s}, 6 \mathrm{H},-\mathrm{CH}_{3}\right), 3.79\left(\mathrm{~s}, 3 \mathrm{H},-\mathrm{CH}_{3}\right)$, $3.68\left(\mathrm{~s}, 2 \mathrm{H},-\mathrm{CH}_{2}-\right), 3.67\left(\mathrm{~s}, 3 \mathrm{H},-\mathrm{CH}_{3}\right), 3.20(\mathrm{t}, J=2.2 \mathrm{~Hz}, 1 \mathrm{H}, \equiv \mathrm{C}-\mathrm{H}) .{ }^{13} \mathrm{C}$ NMR $(100 \mathrm{MHz}$, DMSO- $d_{6}$, ppm) $\delta 173.22,171.82,165.81,152.83,140.84,130.39,130.16,129.27,126.44$, 115.07, 106.86, 97.48, 79.44, 73.36, 60.25, 56.18, 33.68, 19.22. HR-MS (ESI), calcd. $\mathrm{C}_{21} \mathrm{H}_{19} \mathrm{~N}_{5} \mathrm{NaO}_{3} \mathrm{~S}_{2},[\mathrm{M}+\mathrm{Na}]^{+} \mathrm{m} / \mathrm{z}: 476.0827$, found: 476.0828 .

2-(prop-2-yn-1-ylthio)-4-(pyridin-2-ylthio)-6-(3,4,5-trimethoxyphenyl)pyrimidine-5carbonitrile (29)

Yield $80.2 \%$. Yellow solid. Mp: $180-181^{\circ} \mathrm{C} .{ }^{1} \mathrm{H}$ NMR (400 MHz, DMSO- $\left.d_{6}, \mathrm{ppm}\right) \delta 8.76$ $-8.58(\mathrm{~m}, 1 \mathrm{H}, \mathrm{Ar}-\mathrm{H}), 7.97$ (td, $J=7.7,1.7 \mathrm{~Hz}, 1 \mathrm{H}, \mathrm{Ar}-\mathrm{H}), 7.86(\mathrm{~d}, J=7.8 \mathrm{~Hz}, 1 \mathrm{H}, \mathrm{Ar}-\mathrm{H}), 7.55$ (dt, $J=15.7,7.8 \mathrm{~Hz}, 1 \mathrm{H}, \mathrm{Ar}-\mathrm{H}), 7.38(\mathrm{~s}, 2 \mathrm{H}, \mathrm{Ar}-\mathrm{H}), 3.86\left(\mathrm{~s}, 6 \mathrm{H},-\mathrm{CH}_{3}\right), 3.78\left(\mathrm{~s}, 3 \mathrm{H},-\mathrm{CH}_{3}\right)$, $3.71\left(\mathrm{~d}, J=2.2 \mathrm{~Hz}, 2 \mathrm{H},-\mathrm{CH}_{2}-\right), 3.14(\mathrm{t}, J=2.3 \mathrm{~Hz}, 1 \mathrm{H}) .{ }^{13} \mathrm{C}$ NMR (100 MHz, DMSO- $\left.d_{6}, \mathrm{ppm}\right)$ $\delta 172.90,171.53,165.73,152.80,150.76,149.32,140.76,138.08,131.26,129.36,124.71$, 115.22, 106.82, 98.15, 79.54, 73.35, 60.24, 56.14, 19.20. HR-MS (ESI), calcd. $\mathrm{C}_{22} \mathrm{H}_{18} \mathrm{~N}_{4} \mathrm{NaO}_{3} \mathrm{~S}_{2}$, [M+Na] $]^{+} \mathrm{m} / \mathrm{z}: 473.0718$, found: 473.0715 .

4-((5-aminothiophen-2-yl)thio)-2-(prop-2-yn-1-ylthio)-6-(3,4,5-

trimethoxyphenyl)pyrimidine-5-carbonitrile (30)

Yield 89.3\%. Yellow solid. Mp: $189-190^{\circ} \mathrm{C} .{ }^{1} \mathrm{H}$ NMR (400 MHz, DMSO- $\left.d_{6}, \mathrm{ppm}\right) \delta 7.87$ (s, 2H, -CH=), $7.42(\mathrm{~s}, 2 \mathrm{H}, \mathrm{Ar}-\mathrm{H}), 3.95\left(\mathrm{~d}, J=2.1 \mathrm{~Hz}, 2 \mathrm{H},-\mathrm{CH}_{2}-\right), 3.86\left(\mathrm{~s}, 6 \mathrm{H},-\mathrm{CH}_{3}\right), 3.79$ (s, $\left.3 \mathrm{H},-\mathrm{CH}_{3}\right), 3.17(\mathrm{~d}, J=2.2 \mathrm{~Hz}, 1 \mathrm{H}, \equiv \mathrm{C}-\mathrm{H}) .{ }^{13} \mathrm{C}$ NMR $\left(100 \mathrm{MHz}, \mathrm{DMSO}-d_{6}, \mathrm{ppm}\right) \delta 173.78$, $171.83,171.36,165.58,152.84,140.98,129.19,114.91,106.95,97.68,79.43,73.44,60.27$ 56.19, 19.55. HR-MS (ESI), calcd. $\mathrm{C}_{21} \mathrm{H}_{18} \mathrm{~N}_{4} \mathrm{NaO}_{3} \mathrm{~S}_{3}$, [M+Na] $]^{+}$m/z: 493.0439, found: 493.0438 . 4-((5-methyl-1,3,4-thiadiazol-2-yl)thio)-2-(prop-2-yn-1-ylthio)-6-(3,4,5trimethoxyphenyl)pyrimidine-5-carbonitrile (31) 
Yield 76.5\%. White solid. Mp: $186-187^{\circ} \mathrm{C} .{ }^{1} \mathrm{H}$ NMR (400 MHz, DMSO- $\left.d_{6}, \mathrm{ppm}\right) \delta 7.44$ (s, 2H, Ar-H), $3.93\left(\mathrm{~d}, J=2.4 \mathrm{~Hz}, 2 \mathrm{H},-\mathrm{CH}_{2}-\right), 3.87\left(\mathrm{~s}, 6 \mathrm{H},-\mathrm{CH}_{3}\right), 3.80\left(\mathrm{~s}, 3 \mathrm{H},-\mathrm{CH}_{3}\right), 3.20$ (t, $J=2.5 \mathrm{~Hz}, 1 \mathrm{H}, \equiv \mathrm{C}-\mathrm{H}), 2.86\left(\mathrm{~s}, 1 \mathrm{H},-\mathrm{CH}_{3}\right) .{ }^{13} \mathrm{C} \mathrm{NMR}\left(100 \mathrm{MHz}, \mathrm{DMSO}-d_{6}, \mathrm{ppm}\right) \delta 171.88$ 171.26, 169.59, 165.64, 154.06, 152.86, 141.07, 129.09, 114.85, 106.96, 98.14, 79.53, 73.43, 60.27, 56.19, 19.54, 15.53. HR-MS (ESI), calcd. $\mathrm{C}_{20} \mathrm{H}_{17} \mathrm{~N}_{5} \mathrm{NaO}_{3} \mathrm{~S}_{3},[\mathrm{M}+\mathrm{Na}]^{+} \mathrm{m} / \mathrm{z}: 494.0391$, found: 494.0389 .

\section{4-((5-amino-1,3,4-thiadiazol-2-yl)thio)-2-(prop-2-yn-1-ylthio)-6-(3,4,5-}

trimethoxyphenyl)pyrimidine-5-carbonitrile (32)

Yield 65.1\%. White solid. Mp: $181-182^{\circ} \mathrm{C} .{ }^{1} \mathrm{H}$ NMR (400 MHz, DMSO- $\left.d_{6}, \mathrm{ppm}\right) \delta 7.83$ (s, 2H, NH, $\mathrm{D}_{2} \mathrm{O}$ exchangeable), 7.43 (d, $\left.J=0.6 \mathrm{~Hz}, 2 \mathrm{H}, \mathrm{Ar}-\mathrm{H}\right), 3.94$ (t, $J=7.4 \mathrm{~Hz}, 2 \mathrm{H},-\mathrm{CH}_{2}-$ ), $3.87\left(\mathrm{~s}, 6 \mathrm{H},-\mathrm{CH}_{3}\right), 3.79\left(\mathrm{~d}, J=0.8 \mathrm{~Hz}, 3 \mathrm{H},-\mathrm{CH}_{3}\right), 3.18(\mathrm{dd}, J=2.5,1.6 \mathrm{~Hz}, 1 \mathrm{H}, \equiv \mathrm{C}-\mathrm{H}) .{ }^{13} \mathrm{C}$ NMR (100 MHz, DMSO- $d_{6}$, ppm) $\delta 173.82,171.81,171.41,165.59,152.84,140.96,138.79$, $129.21,114.92,106.95,97.71,79.44,73.48,60.26,56.19,19.55$.

4-((1,3,4-thiadiazol-2-yl)thio)-2-(prop-2-yn-1-ylthio)-6-(3,4,5trimethoxyphenyl)pyrimidine-5-carbonitrile (33)

Yield 81.1\%. White solid. Mp: 228-229 ${ }^{\circ} \mathrm{C} .{ }^{1} \mathrm{H}$ NMR (400 MHz, DMSO- $\left.d_{6}, \mathrm{ppm}\right) \delta 9.96$ (s, 1H, - $\mathrm{CH}=), 7.45$ (s, 2H, Ar-H), $3.94\left(\mathrm{~d}, J=2.5 \mathrm{~Hz}, 2 \mathrm{H},-\mathrm{CH}_{2}-\right), 3.87\left(\mathrm{~s}, 6 \mathrm{H},-\mathrm{CH}_{3}\right), 3.79$ (s, $\left.3 \mathrm{H},-\mathrm{CH}_{3}\right), 3.20(\mathrm{t}, J=2.5 \mathrm{~Hz}, 1 \mathrm{H}, \equiv \mathrm{C}-\mathrm{H}) .{ }^{13} \mathrm{C} \mathrm{NMR}\left(100 \mathrm{MHz}, \mathrm{DMSO}-d_{6}, \mathrm{ppm}\right) \delta 171.83$, $169.14,165.64,159.31,155.09,152.88,141.10,129.10,114.85,106.99,98.24,79.51,73.53$, $60.28,56.20,19.57$

\section{2-(prop-2-yn-1-ylthio)-4-(thiazol-2-ylthio)-6-(3,4,5-trimethoxyphenyl)pyrimidine-5-} carbonitrile (34)

Yield $81.1 \%$. White solid. Mp: $172-173^{\circ} \mathrm{C} .{ }^{1} \mathrm{H}$ NMR (400 MHz, DMSO- $\left.d_{6}, \mathrm{ppm}\right), 8.20$ $(\mathrm{d}, J=3.2 \mathrm{~Hz}, 1 \mathrm{H},-\mathrm{CH}=), 8.11(\mathrm{~d}, J=3.2 \mathrm{~Hz}, 1 \mathrm{H},-\mathrm{CH}=), 7.42(\mathrm{~s}, 2 \mathrm{H}, \mathrm{Ar}-\mathrm{H}), 3.87(\mathrm{~s}, 6 \mathrm{H},-$ $\left.\mathrm{CH}_{3}\right), 3.85\left(\mathrm{~s}, 2 \mathrm{H},-\mathrm{CH}_{2}-\right), 3.79\left(\mathrm{~s}, 3 \mathrm{H},-\mathrm{CH}_{3}\right), 3.18(\mathrm{~s}, 1 \mathrm{H}, \equiv \mathrm{C}-\mathrm{H}) .{ }^{13} \mathrm{C}$ NMR (100 MHz, DMSO$\left.d_{6}, \mathrm{ppm}\right) \delta 171.75,171.21,165.61,152.84,150.61,144.13,140.94,129.20,127.64,114.88$, 106.93, 97.72, 79.49, 79.11, 73.49, 60.26, 56.17, 19.41. HR-MS (ESI), calcd. $\mathrm{C}_{20} \mathrm{H}_{16} \mathrm{~N}_{4} \mathrm{NaO}_{3} \mathrm{~S}_{3}$, $[\mathrm{M}+\mathrm{Na}]^{+} \mathrm{m} / \mathrm{z}:$ 479.0282, found: 479.0284 . 
4-((4-methylthiazol-2-yl)thio)-2-(prop-2-yn-1-ylthio)-6-(3,4,5-

trimethoxyphenyl)pyrimidine-5-carbonitrile (35)

Yield 76.7\%. White solid. Mp: $226-227^{\circ} \mathrm{C} .{ }^{1} \mathrm{H}$ NMR (400 MHz, DMSO- $\left.d_{6}, \mathrm{ppm}\right) \delta 7.75$ $(\mathrm{d}, J=0.9 \mathrm{~Hz}, 1 \mathrm{H},-\mathrm{CH}=), 7.41(\mathrm{~s}, 2 \mathrm{H}, \mathrm{Ar}-\mathrm{H}), 3.86\left(\mathrm{~s}, 6 \mathrm{H},-\mathrm{CH}_{3}\right), 3.86(\mathrm{~d}, J=2.8 \mathrm{~Hz}, 2 \mathrm{H},-$ $\left.\mathrm{CH}_{2}-\right), 3.79\left(\mathrm{~s}, 3 \mathrm{H},-\mathrm{CH}_{3}\right), 3.18(\mathrm{t}, J=2.6 \mathrm{~Hz}, 1 \mathrm{H}), 2.46\left(\mathrm{~d}, J=0.8 \mathrm{~Hz}, 3 \mathrm{H},-\mathrm{CH}_{3}\right) .{ }^{13} \mathrm{C} \mathrm{NMR}$ (100 MHz, DMSO- $d_{6}$, ppm) $\delta 171.72,171.36,165.67,153.78,152.84,149.35,140.94,129.23$, 121.97, 114.88, 106.95, 97.72, 79.51, 73.41, 60.26, 56.19, 19.38, 16.73. HR-MS (ESI), calcd. $\mathrm{C}_{21} \mathrm{H}_{18} \mathrm{~N}_{4} \mathrm{NaO}_{3} \mathrm{~S}_{3},[\mathrm{M}+\mathrm{Na}]^{+} \mathrm{m} / \mathrm{z}: 493.0439$, found: 493.0434 .

\section{4-((4,5-dimethylthiazol-2-yl)thio)-2-(prop-2-yn-1-ylthio)-6-(3,4,5-}

trimethoxyphenyl)pyrimidine-5-carbonitrile (36)

Yield 82.9\%. White solid. Mp: $192-193^{\circ} \mathrm{C} .{ }^{1} \mathrm{H}$ NMR (400 MHz, DMSO- $\left.d_{6}, \mathrm{ppm}\right) \delta 7.23$ (s, 2H, Ar-H), $3.70\left(\mathrm{~s}, 6 \mathrm{H},-\mathrm{CH}_{3}\right), 3.62\left(\mathrm{~s}, 3 \mathrm{H},-\mathrm{CH}_{3}\right), 3.22\left(\mathrm{~s}, 2 \mathrm{H},-\mathrm{CH}_{2}-\right), 3.02(\mathrm{~s}, 1 \mathrm{H}, \equiv \mathrm{C}-\mathrm{H})$, $2.29\left(\mathrm{~s}, 3 \mathrm{H},-\mathrm{CH}_{3}\right), 2.19\left(\mathrm{~s}, 3 \mathrm{H},-\mathrm{CH}_{3}\right) .{ }^{13} \mathrm{C}$ NMR (100 MHz, DMSO- $\left.d_{6}, \mathrm{ppm}\right) \delta 171.72,171.36$, $165.67,153.78,152.84,149.35,140.94,129.23,121.97,114.88,106.95,97.72,79.51,73.41$, 60.26, 56.19, 19.38, 16.73, 19.24. HR-MS (ESI), calcd. $\mathrm{C}_{22} \mathrm{H}_{21} \mathrm{~N}_{4} \mathrm{O}_{3} \mathrm{~S}_{3},[\mathrm{M}+\mathrm{H}]+\mathrm{m} / \mathrm{z}: 485.0776$, found: 485.0774 .

4-(benzo[d]thiazol-2-ylthio)-2-(prop-2-yn-1-ylthio)-6-(3,4,5trimethoxyphenyl)pyrimidine-5-carbonitrile (37)

Yield 69.0\%. White solid. Mp: $223-224^{\circ} \mathrm{C} .{ }^{1} \mathrm{H}$ NMR (400 MHz, DMSO- $\left.d_{6}, \mathrm{ppm}\right) \delta 8.25$ $-8.17(\mathrm{~m}, 1 \mathrm{H}, \mathrm{Ar}-\mathrm{H}), 8.10$ (d, $J=7.6 \mathrm{~Hz}, 1 \mathrm{H}, \mathrm{Ar}-\mathrm{H}), 7.58$ (dtd, $J=16.4,7.3,1.3 \mathrm{~Hz}, 2 \mathrm{H}, \mathrm{Ar}-$ $\mathrm{H}), 7.47(\mathrm{~s}, 2 \mathrm{H}, \mathrm{Ar}-\mathrm{H}), 3.92\left(\mathrm{~d}, J=2.4 \mathrm{~Hz}, 2 \mathrm{H},-\mathrm{CH}_{2}-\right), 3.88\left(\mathrm{~s}, 6 \mathrm{H},-\mathrm{CH}_{3}\right), 3.80\left(\mathrm{~s}, 3 \mathrm{H},-\mathrm{CH}_{3}\right)$, $3.15(\mathrm{t}, J=2.5 \mathrm{~Hz}, 1 \mathrm{H}, \equiv \mathrm{C}-\mathrm{H}) .{ }^{13} \mathrm{C}$ NMR $\left(100 \mathrm{MHz}, \mathrm{DMSO}-d_{6}, \mathrm{ppm}\right) \delta 171.72,169.72,165.59$, $155.24,152.86,151.49,141.09,136.73,129.15,126.81,126.23,122.92,122.16,114.86$, 107.01, 98.14, 79.40, 73.39, 60.27, 56.20, 19.52. HR-MS (ESI), calcd. $\mathrm{C}_{24} \mathrm{H}_{18} \mathrm{~N}_{4} \mathrm{NaO}_{3} \mathrm{~S}_{3}$, $[\mathrm{M}+\mathrm{Na}]^{+} \mathrm{m} / \mathrm{z}: 529.0439$, found: 529.0439 .

4-(3-chlorophenyl)-2-(prop-2-yn-1-ylthio)-6-(thiazol-2-ylthio)pyrimidine-5-carbonitrile (38) 
Yield 65.4\%. White solid. Mp: $171-172^{\circ} \mathrm{C} .{ }^{1} \mathrm{H}$ NMR (400 MHz, DMSO- $\left.d_{6}, \mathrm{ppm}\right) \delta 8.24$ $-8.21(\mathrm{~m}, 1 \mathrm{H}, \mathrm{Ar}-\mathrm{H}), 8.13(\mathrm{~d}, J=2.9 \mathrm{~Hz}, 1 \mathrm{H}, \mathrm{Ar}-\mathrm{H}), 8.03(\mathrm{~s}, 1 \mathrm{H}, \mathrm{Ar}-\mathrm{H}), 7.96$ (d, $J=7.6 \mathrm{~Hz}$, $1 \mathrm{H}, \mathrm{Ar}-\mathrm{H}), 7.75(\mathrm{~d}, J=8.0 \mathrm{~Hz}, 1 \mathrm{H},-\mathrm{CH}=), 7.66(\mathrm{t}, J=7.8 \mathrm{~Hz}, 1 \mathrm{H},-\mathrm{CH}=), 3.80\left(\mathrm{~s}, 2 \mathrm{H},-\mathrm{CH}_{2}-\right)$, $3.15(\mathrm{~s}, 1 \mathrm{H}, \equiv \mathrm{C}-\mathrm{H}) .{ }^{13} \mathrm{C}$ NMR $\left(100 \mathrm{MHz}, \mathrm{DMSO}-d_{6}, \mathrm{ppm}\right) \delta 172.10,171.43,165.05,150.21$, $144.34,136.33,133.49,131.82,130.75,128.75,127.96,127.72,114.35,98.60,79.11,73.82$, 19.31. HR-MS (ESI), calcd. $\mathrm{C}_{17} \mathrm{H}_{9} \mathrm{ClN}_{4} \mathrm{NaS}_{3},[\mathrm{M}+\mathrm{Na}]^{+} \mathrm{m} / \mathrm{z}: 422.9576$, found: 422.9577.

\section{4-(4-chlorophenyl)-2-(prop-2-yn-1-ylthio)-6-(thiazol-2-ylthio)pyrimidine-5-carbonitrile} (39)

Yield 73.2\%. White solid. Mp: $136-137^{\circ} \mathrm{C} .{ }^{1} \mathrm{H}$ NMR (400 MHz, DMSO- $\left.d_{6}, \mathrm{ppm}\right) \delta 8.21$ (t, $J=10.7 \mathrm{~Hz}, 1 \mathrm{H},-\mathrm{CH}=), 8.13(\mathrm{~d}, J=3.3 \mathrm{~Hz}, 1 \mathrm{H},-\mathrm{CH}=), 8.03(\mathrm{~d}, J=8.6 \mathrm{~Hz}, 2 \mathrm{H}, \mathrm{Ar}-\mathrm{H}), 7.71$ $(\mathrm{d}, J=8.6 \mathrm{~Hz}, 2 \mathrm{H}, \mathrm{Ar}-\mathrm{H}), 3.79\left(\mathrm{~d}, J=2.4 \mathrm{~Hz}, 2 \mathrm{H},-\mathrm{CH}_{2}-\right), 3.15(\mathrm{t}, J=2.5 \mathrm{~Hz}, 1 \mathrm{H}, \equiv \mathrm{C}-\mathrm{H}) .{ }^{13} \mathrm{C}$ NMR (100 MHz, DMSO- $\left.d_{6}, \mathrm{ppm}\right) \delta 172.00,171.47,165.31,150.28,144.31,137.20,133.13$, 130.92, 128.97, 127.92, 114.47, 98.23, 79.08, 73.86, 19.27. HR-MS (ESI), calcd. $\mathrm{C}_{17} \mathrm{H}_{9} \mathrm{ClN}_{4} \mathrm{NaS}_{3},[\mathrm{M}+\mathrm{Na}]^{+} \mathrm{m} / \mathrm{z}: 422.9576$, found: 422.9578 .

\section{4-(4-bromophenyl)-2-(prop-2-yn-1-ylthio)-6-(thiazol-2-ylthio)pyrimidine-5-carbonitrile} (40)

Yield 78.1\%. White solid. Mp: $238-239^{\circ} \mathrm{C} .{ }^{1} \mathrm{H}$ NMR (400 MHz, DMSO- $\left.d_{6}, \mathrm{ppm}\right) \delta 8.23$ $(\mathrm{d}, J=3.3 \mathrm{~Hz}, 1 \mathrm{H},-\mathrm{CH}=), 8.13(\mathrm{~d}, J=3.3 \mathrm{~Hz}, 1 \mathrm{H},-\mathrm{CH}=), 7.97-7.91(\mathrm{~m}, 2 \mathrm{H}, \mathrm{Ar}-\mathrm{H}), 7.88-$ $7.82(\mathrm{~m}, 2 \mathrm{H}, \mathrm{Ar}-\mathrm{H}), 3.79\left(\mathrm{~d}, J=2.6 \mathrm{~Hz}, 2 \mathrm{H},-\mathrm{CH}_{2}-\right), 3.14(\mathrm{t}, J=2.6 \mathrm{~Hz}, 1 \mathrm{H}, \equiv \mathrm{C}-\mathrm{H}) .{ }^{13} \mathrm{C}$ NMR $\left(100 \mathrm{MHz}, \mathrm{DMSO}-d_{6}, \mathrm{ppm}\right) \delta 172.03,171.48,165.43,150.29,144.31,133.50,131.91,131.04$, 127.91, 126.18, 114.45, 98.20, 79.06, 73.86, 19.29. HR-MS (ESI), calcd. $\mathrm{C}_{17} \mathrm{H}_{9} \mathrm{BrN}_{4} \mathrm{NaS}_{3}$, $[\mathrm{M}+\mathrm{Na}]^{+} \mathrm{m} / \mathrm{z}: 466.9070$, found: 466.9073.

\section{4-(3,4-dichlorophenyl)-2-(prop-2-yn-1-ylthio)-6-(thiazol-2-ylthio)pyrimidine-5- carbonitrile (41)}

Yield $88.0 \%$. White solid. Mp: $142-143^{\circ} \mathrm{C} .{ }^{1} \mathrm{H}$ NMR (400 MHz, DMSO- $\left.d_{6}, \mathrm{ppm}\right) \delta 8.23$ $(\mathrm{d}, J=3.1 \mathrm{~Hz}, 2 \mathrm{H}, \mathrm{Ar}-\mathrm{H}), 8.13(\mathrm{~d}, J=3.3 \mathrm{~Hz}, 1 \mathrm{H}, \mathrm{Ar}-\mathrm{H}), 7.98(\mathrm{dd}, J=8.4,1.7 \mathrm{~Hz}, 1 \mathrm{H},-\mathrm{CH}=)$, $7.91(\mathrm{~d}, J=8.4 \mathrm{~Hz}, 1 \mathrm{H},-\mathrm{CH}=), 3.80\left(\mathrm{~d}, J=2.3 \mathrm{~Hz}, 2 \mathrm{H},-\mathrm{CH}_{2}-\right), 3.15(\mathrm{~s}, 1 \mathrm{H}, \equiv \mathrm{C}-\mathrm{H}) .{ }^{13} \mathrm{C}$ NMR (100 MHz, DMSO- $\left.d_{6}, \mathrm{ppm}\right) \delta 172.14,171.46,164.05,150.12,144.36,135.06,134.74,131.74$, 
131.14, 130.89, 129.11, 127.99, 114.26, 98.58, 79.06, 73.84, 19.35. HR-MS (ESI), calcd. $\mathrm{C}_{17} \mathrm{H}_{8} \mathrm{C}_{12} \mathrm{~N}_{4} \mathrm{NaS}_{3},[\mathrm{M}+\mathrm{Na}]^{+} \mathrm{m} / \mathrm{z}: 456.9186$, found: 456.9187.

2-(prop-2-yn-1-ylthio)-4-(thiazol-2-ylthio)-6-(p-tolyl)pyrimidine-5-carbonitrile (42)

Yield 72.8\%. White solid. Mp: $156-157^{\circ} \mathrm{C} .{ }^{1} \mathrm{H}$ NMR (400 MHz, DMSO- $\left.d_{6}, \mathrm{ppm}\right) \delta 8.21$ $(\mathrm{d}, J=3.3 \mathrm{~Hz}, 1 \mathrm{H},-\mathrm{CH}=), 8.12(\mathrm{~d}, J=3.3 \mathrm{~Hz}, 1 \mathrm{H},-\mathrm{CH}=), 7.93(\mathrm{~d}, J=8.1 \mathrm{~Hz}, 2 \mathrm{H}, \mathrm{Ar}-\mathrm{H}), 7.43$ $(\mathrm{d}, J=8.1 \mathrm{~Hz}, 2 \mathrm{H}, \mathrm{Ar}-\mathrm{H}), 3.80\left(\mathrm{~d}, J=2.5 \mathrm{~Hz}, 2 \mathrm{H},-\mathrm{CH}_{2}-\right), 3.15(\mathrm{t}, J=2.4 \mathrm{~Hz}, 1 \mathrm{H}, \equiv \mathrm{C}-\mathrm{H}), 2.41$ $\left(\mathrm{d}, J=6.0 \mathrm{~Hz}, 3 \mathrm{H},-\mathrm{CH}_{3}\right) .{ }^{13} \mathrm{C}$ NMR $\left(100 \mathrm{MHz}, \mathrm{DMSO}-d_{6}, \mathrm{ppm}\right) \delta 172.22,169.63,166.35$, $159.27,145.52,135.41,130.15,121.20,118.09,114.67,114.17,98.78,78.95,73.42,55.43$, 34.76, 19.11. HR-MS (ESI), calcd. $\mathrm{C}_{18} \mathrm{H}_{12} \mathrm{~N}_{4} \mathrm{NaS}_{3}$, [M+Na $]^{+}$m/z: 403.0122, found: 403.0123 . 4-(2-oxo-2H-chromen-6-yl)-2-(prop-2-yn-1-ylthio)-6-(thiazol-2-ylthio)pyrimidine-5carbonitrile (43)

Yield 90.8\%. Yellow solid. Mp: $226-227^{\circ} \mathrm{C} .{ }^{1} \mathrm{H}$ NMR (400 MHz, DMSO-d 6 , ppm) $\delta 8.37$ $(\mathrm{d}, J=1.9 \mathrm{~Hz}, 1 \mathrm{H}, \mathrm{Ar}-\mathrm{H}), 8.23$ (d, $J=3.3 \mathrm{~Hz}, 1 \mathrm{H}, \mathrm{Ar}-\mathrm{H}), 8.22$ (d, $J=2.5 \mathrm{~Hz}, 1 \mathrm{H},-\mathrm{CH}=), 8.20$ (s, $1 \mathrm{H},-\mathrm{CH}=), 8.13(\mathrm{~d}, J=3.3 \mathrm{~Hz}, 1 \mathrm{H},-\mathrm{CH}=), 7.64(\mathrm{~d}, J=8.7 \mathrm{~Hz}, 1 \mathrm{H},-\mathrm{CH}=), 6.62(\mathrm{~d}, J=9.6$ $\mathrm{Hz}, 1 \mathrm{H}, \mathrm{Ar}-\mathrm{H}), 3.80\left(\mathrm{~d}, J=2.4 \mathrm{~Hz}, 2 \mathrm{H},-\mathrm{CH}_{2}-\right), 3.16(\mathrm{t}, J=2.4 \mathrm{~Hz}, 1 \mathrm{H}, \equiv \mathrm{C}-\mathrm{H}) .{ }^{13} \mathrm{C}$ NMR $(100$ MHz, DMSO- $\left.d_{6}, \mathrm{ppm}\right) \delta 172.02,171.52,165.02,159.35,155.67,150.23,144.34,143.75$, 132.30, 130.47, 129.70, 127.97, 118.99, 117.34, 117.01, 114.53, 98.15, 79.08, 73.94, 19.32 . HR-MS (ESI), calcd. $\mathrm{C}_{20} \mathrm{H}_{10} \mathrm{~N}_{4} \mathrm{O}_{2} \mathrm{NaS}_{3}$, [M+Na] $]^{+} \mathrm{m} / \mathrm{z}$ : 456.9864, found: 456.9862.

2-(prop-2-yn-1-ylthio)-4-(pyridin-4-yl)-6-(thiazol-2-ylthio)pyrimidine-5-carbonitrile (44)

Yield 76.3\%. White solid. Mp: $189-190^{\circ} \mathrm{C} .{ }^{1} \mathrm{H}$ NMR (400 MHz, DMSO- $\left.d_{6}, \mathrm{ppm}\right) \delta 8.87$ (dd, J = 4.5, 1.5 Hz, 2H, Ar-H), 8.24 (d, J = 3.3 Hz, 1H, -CH=), 8.14 (d, J = 3.3 Hz, 1H, -CH=), $7.91(\mathrm{dd}, \mathrm{J}=4.5,1.6 \mathrm{~Hz}, 2 \mathrm{H}, \mathrm{Ar}-\mathrm{H}), 3.79\left(\mathrm{~d}, \mathrm{~J}=2.5 \mathrm{~Hz}, 2 \mathrm{H},-\mathrm{CH}_{2}-\right), 3.14$ (t, J = 2.6 Hz, 1H, $\equiv \mathrm{C}-\mathrm{H}) .{ }^{13} \mathrm{C}$ NMR $\left(100 \mathrm{MHz}, \mathrm{D}\right.$ MSO- $\left.d_{6}, \mathrm{ppm}\right) \delta 190.70,176.34,166.45,165.53,149.87,142.64$, 140.34, 121.31, 118.64, 117.01, 96.91, 76.90, 73.97, 25.02. HR-MS (ESI), calcd. $\mathrm{C}_{16} \mathrm{H}_{9} \mathrm{~N}_{5} \mathrm{NaS}_{3}$, $[\mathrm{M}+\mathrm{Na}]^{+} \mathrm{m} / \mathrm{z}: 389.9918$, found: 389.9919 .

2-(prop-2-yn-1-ylthio)-4-(1H-pyrrol-2-yl)-6-(thiazol-2-ylthio)pyrimidine-5-carbonitrile (45) 
Yield 80.1\%. White solid. Mp: $255-256^{\circ} \mathrm{C} .{ }^{1} \mathrm{H}$ NMR (400 MHz, DMSO- $\left.d_{6}, \mathrm{ppm}\right) \delta 12.05$ (s, $1 \mathrm{H}, \mathrm{NH}, \mathrm{D}_{2} \mathrm{O}$ exchangeable), $8.17(\mathrm{~d}, J=3.3 \mathrm{~Hz}, 1 \mathrm{H},-\mathrm{CH}=), 8.08(\mathrm{~d}, J=3.3 \mathrm{~Hz}, 1 \mathrm{H},-\mathrm{CH}=)$, $7.56-7.43(\mathrm{~m}, 1 \mathrm{H},-\mathrm{CH}=), 7.30(\mathrm{~s}, 1 \mathrm{H},-\mathrm{CH}=), 6.42(\mathrm{dt}, J=4.2,2.3 \mathrm{~Hz}, 1 \mathrm{H},-\mathrm{CH}=), 3.94(\mathrm{~d}, J$ $\left.=2.5 \mathrm{~Hz}, 2 \mathrm{H},-\mathrm{CH}_{2}-\right), 3.15(\mathrm{t}, J=2.6 \mathrm{~Hz}, 1 \mathrm{H}, \equiv \mathrm{C}-\mathrm{H}) .{ }^{13} \mathrm{C}$ NMR $\left(100 \mathrm{MHz}, \mathrm{DMSO}-d_{6}, \mathrm{ppm}\right) \delta$ $171.25,170.38,155.31,150.94,143.92,127.38,127.03,125.56,116.89,115.36,112.01,91.23$, 79.30, 73.98, 19.04. HR-MS (ESI), calcd. $\mathrm{C}_{15} \mathrm{H}_{9} \mathrm{~N}_{5} \mathrm{NaS}_{3}$, $[\mathrm{M}+\mathrm{Na}]^{+} \mathrm{m} / \mathrm{z}: 377.9918$, found: 377.9917.

4-(4-chlorophenyl)-6-((1-(2-(dimethylamino)ethyl)-1H-tetrazol-5-yl)thio)-2-(prop-2-yn1-ylthio)pyrimidine-5-carbonitrile (46)

Yield $89.0 \%$. White solid. Mp: $194-196^{\circ} \mathrm{C} .{ }^{1} \mathrm{H}$ NMR (400 MHz, DMSO- $\left.d_{6}, \mathrm{ppm}\right) \delta 8.00$ (d, $J=8.5 \mathrm{~Hz}, 2 \mathrm{H}, \mathrm{Ar}-\mathrm{H}), 7.69$ (d, $J=8.5 \mathrm{~Hz}, 2 \mathrm{H}, \mathrm{Ar}-\mathrm{H}), 4.94\left(\mathrm{t}, J=6.1 \mathrm{~Hz}, 2 \mathrm{H},-\mathrm{CH}_{2}-\right), 3.61$ (s, 4H, - $\left.\mathrm{CH}_{2}-\right), 3.10(\mathrm{~s}, 1 \mathrm{H}, \equiv \mathrm{C}-\mathrm{H}), 2.85\left(\mathrm{~s}, 6 \mathrm{H},-\mathrm{CH}_{3}\right) \cdot{ }^{13} \mathrm{C}$ NMR (100 MHz, DMSO-d 6 , ppm) $\delta 172.32,169.75,165.42,146.12,137.45,132.85,130.83,129.10,114.52,98.73,78.84,73.55$, 54.27, 42.58, 19.16. HR-MS (ESI), calcd. $\mathrm{C}_{19} \mathrm{H}_{18} \mathrm{ClN}_{8} \mathrm{~S}_{2}$, $[\mathrm{M}+\mathrm{H}]^{+} \mathrm{m} / \mathrm{z}$ : 457.0784, found: 457.0785 .

4-(3-chlorophenyl)-6-((1-(2-(dimethylamino)ethyl)-1H-tetrazol-5-yl)thio)-2-(prop-2-yn1-ylthio)pyrimidine-5-carbonitrile (47)

Yield 75.2\%. Yellow solid. Mp: $179-180^{\circ} \mathrm{C} .{ }^{1} \mathrm{H}$ NMR (400 MHz, DMSO- $\left.d_{6}, \mathrm{ppm}\right) \delta 8.02$ (s, 1H, Ar-H), 7.97 (d, J=7.9 Hz, 1H, Ar-H), $7.81-7.75$ (m, 1H, -CH=), 7.69 (t, J=7.9 Hz, $1 \mathrm{H},-\mathrm{CH}=), 4.99\left(\mathrm{t}, J=6.6 \mathrm{~Hz}, 2 \mathrm{H},-\mathrm{CH}_{2}-\right), 3.69\left(\mathrm{t}, J=5.1 \mathrm{~Hz}, 2 \mathrm{H},-\mathrm{CH}_{2}-\right), 3.67(\mathrm{~d}, J=2.2 \mathrm{~Hz}$, $\left.2 \mathrm{H},-\mathrm{CH}_{2}-\right), 3.21(\mathrm{t}, J=2.4 \mathrm{~Hz}, 1 \mathrm{H}, \equiv \mathrm{C}-\mathrm{H}), 2.84\left(\mathrm{~s}, 6 \mathrm{H},-\mathrm{CH}_{3}\right) .{ }^{13} \mathrm{C}$ NMR $(100 \mathrm{MHz}$, DMSO$\left.d_{6}, \mathrm{ppm}\right) \delta 172.34,169.87,165.06,146.17,136.11,133.61,132.04,130.93,128.64,127.64$ 114.45, 99.20, 78.85, 73.69, 54.14, 42.72, 42.41, 19.24. HR-MS (ESI), calcd. $\mathrm{C}_{19} \mathrm{H}_{18} \mathrm{ClN}_{8} \mathrm{~S}_{2}$, $[\mathrm{M}+\mathrm{H}]^{+} \mathrm{m} / \mathrm{z}: 457.0784$, found: 457.0785 .

4-((1-(2-(dimethylamino)ethyl)-1H-tetrazol-5-yl)thio)-2-(prop-2-yn-1-ylthio)-6-(ptolyl)pyrimidine-5-carbonitrile (48)

Yield 46.0\%. White solid. Mp: $190-191^{\circ} \mathrm{C} .{ }^{1} \mathrm{H}$ NMR (400 MHz, DMSO-d 6 , ppm) $\delta 7.94$ $(\mathrm{d}, J=8.2 \mathrm{~Hz}, 2 \mathrm{H}, \mathrm{Ar}-\mathrm{H}), 7.45(\mathrm{~d}, J=8.2 \mathrm{~Hz}, 2 \mathrm{H}, \mathrm{Ar}-\mathrm{H}), 4.97$ (t, $\left.J=6.4 \mathrm{~Hz}, 2 \mathrm{H},-\mathrm{CH}_{2}-\right), 3.65$ 
$\left(\mathrm{d}, J=2.3 \mathrm{~Hz}, 4 \mathrm{H},-\mathrm{CH}_{2}-\right), 3.20(\mathrm{t}, J=2.3 \mathrm{~Hz}, 1 \mathrm{H}, \equiv \mathrm{C}-\mathrm{H}), 2.81\left(\mathrm{~s}, 6 \mathrm{H},-\mathrm{CH}_{3}\right), 2.43(\mathrm{~s}, 3 \mathrm{H},-$ $\left.\mathrm{CH}_{3}\right) .{ }^{13} \mathrm{C}$ NMR (100 MHz, DMSO- $\left.d_{6}, \mathrm{ppm}\right) \delta 172.05,169.89,166.23,146.24,142.93,131.32$, 129.54, 129.01, 114.87, 98.23, 78.92, 73.67, 54.29, 42.83, 42.49, 21.11, 19.13. HR-MS (ESI), calcd. $\mathrm{C}_{20} \mathrm{H}_{21} \mathrm{~N}_{8} \mathrm{~S}_{2}$, [M+H] $]^{+}$m/z: 437.1331, found: 437.1330 .

4-(3,4-dichlorophenyl)-6-((1-(2-(dimethylamino)ethyl)-1H-tetrazol-5-yl)thio)-2-(prop-2yn-1-ylthio)pyrimidine-5-carbonitrile (49)

Yield 46.0\%. White solid. Mp: $174-175^{\circ} \mathrm{C} .{ }^{1} \mathrm{H}$ NMR (400 MHz, DMSO- $\left.d_{6}, \mathrm{ppm}\right) \delta 8.23$ (s, 1H, Ar-H), 7.97 (dd, $J=17.7,8.2 \mathrm{~Hz}, 2 \mathrm{H}, \mathrm{Ar}-\mathrm{H}), 4.98$ (t, $\left.J=6.3 \mathrm{~Hz}, 2 \mathrm{H},-\mathrm{CH}_{2}-\right), 3.69$ (s, $\left.2 \mathrm{H},-\mathrm{CH}_{2}-\right), 3.68\left(\mathrm{~s}, 2 \mathrm{H},-\mathrm{CH}_{2}-\right), 3.21(\mathrm{~s}, 1 \mathrm{H}, \equiv \mathrm{C}-\mathrm{H}), 2.83\left(\mathrm{~s}, 3 \mathrm{H},-\mathrm{CH}_{3}\right) .{ }^{13} \mathrm{C}$ NMR $(100 \mathrm{MHz}$, DMSO- $d_{6}$, ppm) $\delta 172.40,169.87,164.10,146.12,135.29,134.53,131.88,131.33,130.77$, 129.03, 114.35, 99.21, 78.82, 73.70, 54.15, 42.74, 42.44, 19.27. HR-MS (ESI), calcd. $\mathrm{C}_{19} \mathrm{H}_{17} \mathrm{C}_{12} \mathrm{~N}_{8} \mathrm{~S}_{2},[\mathrm{M}+\mathrm{H}]^{+} \mathrm{m} / \mathrm{z}: 491.0395$, found: 491.0395 .

\section{4-((1-(2-(dimethylamino)ethyl)-1H-tetrazol-5-yl)thio)-6-(2-oxo-2H-chromen-6-yl)-2-}

(prop-2-yn-1-ylthio)pyrimidine-5-carbonitrile (50)

Yield 72.4\%. Yellow solid. Mp: $197-198^{\circ} \mathrm{C} .{ }^{1} \mathrm{H}$ NMR (400 MHz, DMSO- $\left.d_{6}, \mathrm{ppm}\right) \delta 8.39$ (s, 1H, Ar-H), $8.27-8.19$ (m, 2H, Ar-H), $7.66(\mathrm{~d}, J=8.7 \mathrm{~Hz}, 1 \mathrm{H}, \mathrm{Ar}-\mathrm{H}), 6.63(\mathrm{~d}, J=9.6 \mathrm{~Hz}$, $1 \mathrm{H}, \mathrm{Ar}-\mathrm{H}), 5.00\left(\mathrm{t}, J=6.5 \mathrm{~Hz}, 2 \mathrm{H},-\mathrm{CH}_{2}-\right), 3.69\left(\mathrm{~d}, J=4.9 \mathrm{~Hz}, 2 \mathrm{H},-\mathrm{CH}_{2}-\right), 3.66(\mathrm{~d}, J=1.9 \mathrm{~Hz}$, $\left.2 \mathrm{H},-\mathrm{CH}_{2}-\right), 3.23(\mathrm{t}, J=2.3 \mathrm{~Hz}, 1 \mathrm{H}, \equiv \mathrm{C}-\mathrm{H}), 2.83\left(\mathrm{~s}, 6 \mathrm{H},-\mathrm{CH}_{3}\right) .{ }^{13} \mathrm{C}$ NMR $(100 \mathrm{MHz}$, DMSO$\left.d_{6}, \mathrm{ppm}\right) \delta 172.25,169.97,165.07,159.32,155.78,146.19,143.74,132.17,130.26,129.65$ 119.12, 117.43, 117.17, 114.64, 98.72, 78.82, 73.79, 54.23, 42.81, 42.46, 42.34, 19.22. HR-MS (ESI), calcd. $\mathrm{C}_{22} \mathrm{H}_{18} \mathrm{~N}_{8} \mathrm{NaO}_{2} \mathrm{~S}_{2},[\mathrm{M}+\mathrm{Na}]^{+} \mathrm{m} / \mathrm{z}$ : 513.0892, found: 513.0893 .

\section{2-(allylthio)-4-(4-chlorophenyl)-6-(thiazol-2-ylthio)pyrimidine-5-carbonitrile (51)}

Yield 56.0\%. White solid. Mp: $109-110^{\circ} \mathrm{C} .{ }^{1} \mathrm{H}$ NMR $\left(400 \mathrm{MHz}, \mathrm{CDCl}_{3}\right) \delta 8.19(\mathrm{~d}, J=3.3$ $\mathrm{Hz}, 1 \mathrm{H}, \mathrm{Ar}-\mathrm{H}), 8.11$ (d, J=3.3 Hz, 1H, Ar-H), $8.03-7.85$ (m, 2H, Ar-H), $7.77-7.60$ (m, 2H, $\operatorname{Ar}-\mathrm{H}), 5.70(\mathrm{dd}, J=16.9,10.1 \mathrm{~Hz}, 1 \mathrm{H},-\mathrm{CH}=), 5.28-4.98(\mathrm{~m}, 2 \mathrm{H},-\mathrm{CH} 2-), 3.56(\mathrm{~d}, J=6.8 \mathrm{~Hz}$, 2H, -CH2-). ${ }^{13} \mathrm{C}$ NMR (101 MHz, DMSO) $\delta$ 173.13, 171.37, 165.31, 150.35, 144.44, 137.05, 133.23, 132.71, 130.83, 128.94, 128.09, 118.36, 114.57, 97.88, 33.16. HR-MS (ESI), calcd. $\mathrm{C}_{17} \mathrm{H}_{11} \mathrm{ClN}_{4} \mathrm{NaS}_{3},[\mathrm{M}+\mathrm{Na}]^{+} \mathrm{m} / \mathrm{z}: 424.9732$. found: 424.9730 . 


\section{4-(4-chlorophenyl)-2-(propylthio)-6-(thiazol-2-ylthio)pyrimidine-5-carbonitrile (52)}

Yield 48.2\%. White solid. Mp: 112-113 ${ }^{\circ} \mathrm{C} .{ }^{1} \mathrm{H}$ NMR (400 MHz, DMSO) $\delta 8.25$ (d, $J=3.3$ Hz, 1H, Ar-H), 8.15 (d, J=3.3 Hz, 1H, Ar-H), $8.02-7.89$ (m, 2H, Ar-H), 7.70 (dd, $J=8.9,2.1$ $\mathrm{Hz}, 2 \mathrm{H}, \mathrm{Ar}-\mathrm{H}), 2.82\left(\mathrm{t}, J=7.2 \mathrm{~Hz}, 2 \mathrm{H},-\mathrm{CH}_{2}-\right), 1.46$ (dd, $\left.J=14.5,7.3 \mathrm{~Hz}, 2 \mathrm{H},-\mathrm{CH}_{2}-\right), 0.86$ (t, $\left.J=7.3 \mathrm{~Hz}, 3 \mathrm{H},-\mathrm{CH}_{3}\right) .{ }^{13} \mathrm{C}$ NMR $(101 \mathrm{MHz}, \mathrm{DMSO}) \delta 173.90,171.38,165.19,150.25,144.56$, 136.97, 133.29, 130.79, 128.93, 128.26, 114.65, 97.58, 32.44, 21.92, 13.05. HR-MS (ESI), calcd. $\mathrm{C}_{17} \mathrm{H}_{13} \mathrm{ClN}_{4} \mathrm{NaS}_{3},[\mathrm{M}+\mathrm{Na}]^{+} \mathrm{m} / \mathrm{z}$ : 426.9889. found: 426.9890 .

2-(((1-benzyl-1H-1,2,3-triazol-4-yl)methyl)thio)-4-(4-chlorophenyl)-6-(thiazol-2ylthio)pyrimidine-5-carbonitrile (54)

Yield 32.6\%. White solid. Mp: $177-178^{\circ} \mathrm{C} .{ }^{1} \mathrm{H}$ NMR (400 MHz, DMSO- $\left.d_{6}, \mathrm{ppm}\right) \delta 8.08$ (d, $J=3.3 \mathrm{~Hz}, 1 \mathrm{H},-\mathrm{CH}=), 7.99$ (d, $J=2.4 \mathrm{~Hz}, 2 \mathrm{H}, \mathrm{Ar}-\mathrm{H}), 7.97$ (s, 1H, Ar-H), 7.87 (s, 1H, ArH), $7.69(\mathrm{~d}, J=8.6 \mathrm{~Hz}, 2 \mathrm{H}, \mathrm{Ar}-\mathrm{H}), 7.36(\mathrm{td}, J=8.8,4.4 \mathrm{~Hz}, 3 \mathrm{H}, \mathrm{Ar}-\mathrm{H}), 7.30-7.23$ (m, 2H, Ar$\mathrm{H}), 5.53$ (s, 2H, S-CH $\left.2^{-}\right), 4.24$ (s, 2H, $\left.-\mathrm{CH}_{2}-\right) .{ }^{13} \mathrm{C}$ NMR (100 MHz, DMSO- $\left.d_{6}, \mathrm{ppm}\right) \delta 190.71$, $176.32,166.40,165.5,142.63,134.33,133.78,130.78,129.37,128.96,128.63,127.62,125.79$, 122.96, 118.62, 117.05, 96.95, 57.32, 35.20. HR-MS (ESI), calcd. $\mathrm{C}_{24} \mathrm{H}_{16} \mathrm{ClN}_{7} \mathrm{NaS}_{3},[\mathrm{M}+\mathrm{Na}]^{+}$ m/z: 556.0216, found: 556.0217.

Reagents. Rabbit monoclonal antibodies against DCN1 (ab181233), Cullin1 (ab75817), Cullin2 (ab166917), Cullin3 (ab75851), UBE2M (ab109507), p21 (ab109520) and Cullin5 (ab184177) were purchased from Abcam Biotechnology (Cambridge, UK). Anti-DCN1 (GWBE3D700) antibody was from Genway Biotech (San Diego, CA). Mouse monoclonal antibody against CyclinE1 (4129) was purchased from Cell Signaling Technologies. Rabbit polyclonal antibodies against CDT1 (14382-1-AP), HO-1/HMOX1 (10701-1-AP), NQO1 (11451-1-AP), NRF2 (16396-1-AP), CUL4A (14851-1-AP) and CUL4B (12916-1-AP) were purchased from Proteintech (Wuhan, China).

E.coli DH5 $\alpha$ and BL21(DE3) were obtained from Life technologies. E.coli BL21-AI was 
purchased from Invitrogen. Kanamycin, isopropyl- $\beta$-D-galactopyranoside(IPTG) (I8070), L(+)-Arabinose(L8060), Bicinchoninic Acid (BCA) Protein Assay kit (PC0020), 3-(4,5dimethylthiazol-2-yl)-2,5-diphenyltetrazolium bromide (MTT) (M8180) and Glutathione were purchased from Solarbio (China). Ni-beads and GST-trap column were purchased from QIAGEN (USA). Annexin-V-FITC/PI apoptosis kit(KGA106) were purchased from Keygen Biotech(China). Enhanced chemiluminescence (QL228436) and Lipofectamine ${ }^{\circledR}$ RNAiMAX Reagent(13778030) were purchased from Thermo Fisher Scientific. HTRF detection buffer (62SDBRDD), Streptavidin-XL665 (610SAXLA), Anti-GST-Cryptate Gold 61GSTKLA) were purchased from Cisbio Bioassays. NEDD8 Conjugation Initiation Kit was obtained from Boston BioChem (Cambridge, MA, USA). 5000×Sypro Orange dye was purchased from Invitrogen. Super Streptavidin (SSA) sensor was purchased from Fortebio.

Cell Lines. Cells were cultivated in corresponding medium supplemented with 10\% FBS and $5 \% \mathrm{CO} 2$ at $37^{\circ} \mathrm{C}$. Human esophageal carcinoma cell lines EC109, EC9706, TE-1, human lung carcinoma cell lines PC9, A549 and H1975, prostate carcinoma cell line PC3 and liver carcinoma cell lines BEL-7402, SMMC-7721 and ZIP177 were obtained from Cell Bank of the Chinese Academy of Sciences (Shanghai, China). Human esophageal carcinoma cell lines KYSE-70 and KYSE-140 and human immortalized normal esophageal epithelial cell Het-1A were obtained as gifts from the First Affiliated Hospital of Zhengzhou University, which were purchased from the American Type Culture Collection (Manassas, VA, USA). Human gastric epithelial mucosa cell line GES-1 and human breast cancer cell line MCF-7 were purchased from the State Key Laboratory of Molecular Oncology, Chinese Academy of Medical Sciences (Beijing, China). 
Expression and Purification of DCN1-5 Proteins. Human pDEST17-DCN1 (residues 58259) plasmid containing N-terminal His 6 tag was a gift from Dr. Shaomeng Wang's group in University of Michigan Ann Arbor. DCN1 (residues 58-259), DCN2 (residues 62-259), DCN3 (residues 86-304), DCN4 (residues102-292) and DCN5 (residues 47-237) were cloned into an N-terminal GST tag plasmid pGEX4T-1. The plasmids pDEST17-DCN1 and pGEX4T-1DCN1-5 were transformed into E. coli BL21-AI and BL21(DE3), respectively. A preculture was grown in medium containing $50 \mu \mathrm{g} / \mathrm{ml}$ ampicillin at $37^{\circ} \mathrm{C}$. When the cells grew until $\mathrm{OD}_{600}>0.7$ after about $5-8$ hours, $4 \mathrm{mg} / \mathrm{mL}$ L-(+)-Arabinose and $0.25 \mathrm{mM}$ isopropyl- $\beta$-Dgalactopyranoside (IPTG) were added to the culture medium to induce the protein synthesis for $8 \mathrm{~h}$ at $20^{\circ} \mathrm{C}$. Subsequently, the cells were collected and disrupted in ice-cold washing buffer (25mM Tris- $\mathrm{HCl} \mathrm{pH} 7.5,1 \mathrm{mM}$ DTT, $200 \mathrm{mM} \mathrm{NaCl})$ by sonication. The soluble and pellet fractions were separated by centrifugation at $12,000 \mathrm{~g}$ for $15 \mathrm{~min}$. After filtration, cleared filtrate containing N-terminal $\mathrm{His}_{6}$ tag protein was applied to a Ni-beads column and washed with washing buffer containing different concentration of imidazole. The filtrate containing Nterminal GST tag protein was then purified by GST-trap column and washed with washing buffer containing $10 \mathrm{mM}$ glutathione. Afterwards, the molecular weights of these proteins were confirmed by Commassie Blue staining and the concentration of the recombinant proteins were determined, using a Bicinchoninic Acid (BCA) Protein Assay kit.

Competitive FP Binding Assay. The fluorescence polarization (FP) competitive binding assays were performed similarly as described previously. ${ }^{30,32} \mathrm{FP}$ assays were carried out in 96well, black, round-bottom microtiter plates. The FAM-labed fluorescent probe (FAM-782) with a $\mathrm{K}_{\mathrm{d}}$ value of $120.43 \mathrm{nM}$ for DCN1 and the analyzing protocol ${ }^{35}$ were kindly provided by 
Shaomeng Wang's group in University of Michigan Ann Arbor for compounds screening. ${ }^{30}$ DCN1 containing N-terminal His 6 tag was used for FP binding assay. DCN1 and the probe were mixed to a final volume of $100 \mu \mathrm{L}$ in the assay buffer $(100 \mathrm{mM}$ phosphate buffer, $\mathrm{PH}=6.5,0.02 \%$ Tween-20). After shaking at room temperature for 30min, the plates were measured by PerkinElmer Envision microplate reader at an excitation wavelength of $485 \mathrm{~nm}$ and an emission wavelength of $530 \mathrm{~nm}$. The data were analyzed by SPSS 20 and GraphPad Prism 5 software. $\mathrm{K}_{\mathrm{i}}$ values were calculated based on the methods described earlier. ${ }^{32,74}$ The equation is: $K_{\mathrm{i}}=[]_{50} /$ $\left([L]_{50} / K_{\mathrm{d}}+[P]_{0} / K_{\mathrm{d}}+1\right)$, where $[I]_{50}$ is the concentration of the inhibitor at $50 \%$ inhibition, $[L]_{50}$ is the concentration of the ligand at $50 \%$ inhibition, $K_{\mathrm{d}}$ is the dissociation constant of the protein-ligand complex, and $[P]_{0}$ is the concentration of the protein at $0 \%$ inhibition.

HTRF Assay. HTRF assays were carried out in 384-well, white, round-bottom micro-titer plates at a final volume of $20 \mu \mathrm{L}$ per well. The assay cocktail was prepared as a mixture of HTRF detection buffer(62SDBRDD), Streptavidin-XL665(610SAXLA), Anti-GST-Cryptate Gold(61GSTKLA), 5nM GST-DCN1-5, 5nM AcUBE2M ${ }^{1-21}$-biotin, in assay buffer (100mM phosphate buffer, $\mathrm{PH}=6.5, \quad 0.02 \%$ Tween-20). The AcUBE2 $\mathrm{M}^{1-21}$-biotin peptide was synthetized by China peptide company (Shanghai, China) and its sequence is AcMIKLFSLKQQKKEEESAGGTK-biotin. The cocktail was incubated for 30min at room temperature. Compounds to be screened were added to assay plates and the control well were added in the same volume of DMSO solution. The assay mixture was incubated for 30min at room temperature before the measurement of the HTRF signal with a PerkinElmer Envision microplate reader equipped with modules for excitation at 320nm and emission at 615 and $665 \mathrm{~nm}$. The data were analyzed by SPSS 20 and GraphPad Prism 5 software. $\mathrm{K}_{\mathrm{i}}$ values were 
calculated based on the methods described earlier. ${ }^{77}$

Normal Thermal Shift Assay. The assay was performed on C1000 Touch Thermal cyclerCFX96TM Real-Time PCR (BIO-RAD), using the 96-well thin-wall PCR plate. The buffer used in this experiment is $100 \mathrm{mM}$ phosphate buffer, $\mathrm{PH}=6.5,0.02 \%$ Tween-20. A total volume of $25 \mu 1$ solution containing $0.2 \mathrm{mg} / \mathrm{ml}$ DCN1 protein, compounds (DC-2, DC-2N and NAcMCOV) and $1 \times$ Sypro Orange dye was dispensed into the 96 -well plate. The same volume of DMSO was used as control. Then, the plates were heated in Cycler from 25 to $95^{\circ} \mathrm{C}$ ( 71 heating cycles in $35.5 \mathrm{~min})$. The data were analyzed by BIO-RAD software. ${ }^{56}$

Cellular Thermal Shift Assay (CETSA). CETSA was performed to detect the ability of compounds interacting with its targets at cellular level. ${ }^{75}$ Firstly, the cultured cells were treated with cell media containing 1\% DMSO or $10 \mu \mathrm{M}$ compounds DI-591, DC-2 and DC-2N for 35h, respectively, the cells were collected, aliquoted into 7 PCR tubes and then heated for 10 minutes from $43^{\circ} \mathrm{C}$ to $61^{\circ} \mathrm{C}$. As for the dose dependent assay, $1 \%$ DMSO, $0.3,1,3,10 \mu \mathrm{M} \mathrm{DC}$ 2 or $10 \mu \mathrm{M}$ DC-2N were added into the cells for $3-5 \mathrm{~h}$ and then heated for $10 \mathrm{~min}$ at $55^{\circ} \mathrm{C}$. After that, the cells were lysed by three repeated cycles of freeze-thawing, using liquid nitrogen. Finally, after centrifuging at $12,000 \times \mathrm{g}$ for 20 minutes, the supernates were used for Western Blot analysis.

Molecular Docking. The crystal structure (PDB ID: 3TDU, resolution of $1.5 \AA$ ) of human Cul1WHB-Den1P-acetylated Ubc12N complex was obtained from the RCSB protein data bank. The preparation of protein structure was performed under Amber 10: EHT force field, using the Quickprep module with the default parameters, which included the addition of hydrogen atoms, the deletion of solvent, the repair of the missing residues and the setup of the protonation states 
of the ionizable residues with $\mathrm{pKa}=7$. The ligand was prepared under Amber 10: EHT force field by energy minimization and conformational search. Afterwards, we got the conformational database of ligand structure for further docking study. Then, all of the conformations were docked into the binding pocket of human DCN1 with the default parameters, using the method of molecular docking. The docking structure was scored by GBVI/WSA dG and held 20 docking poses in the case of parameters by default.

Co-immunoprecipitation Assay. H1975 cells were treated with 1\%o DMSO, $10 \mu \mathrm{M}$ compound DC-2N, DC-2 or NAcM-COV, respectively, for 5h. Then, the cells were collected and lysed with RIPA buffer. The whole cell lysate was incubated by UBE2M antibody and protein A/G PLUS-Agarose (sc-2003, Santa Cruz Biotech, CA). DCN1 and UBE2M protein associated with beads was eluted by heating and detected by immunoblotting.

Cell-free NAE activity assay. NAE activity assay (in vitro NEDD8 UBE2M formation assay) was conducted according to the manufacturer's instructions. In brief, NEDD8 E1 was mixed with NEDD8, UBE2M and 10 and $20 \mu \mathrm{M}$ MLN4924 or 1, 10 and $100 \mu \mathrm{M}$ DC-2 in the reaction buffer and incubated at room temperature for 10 minutes. The reaction was initiated by the addition of Mg-ATP solution. After 60 min's incubation at $37^{\circ} \mathrm{C}$, the reaction mixtures were added with $1 \mathrm{mM}$ DTT and protein loading buffer (no DTT). The mixtures were then separated by a $12 \%$ SDS-PAGE gel. ${ }^{76}$

Cell Viability Assay. 3-(4,5-dimethylthiazol-2-yl)-2,5-diphenyltetrazolium bromide (MTT) was used to measure the cell viability, according to the manufacturer's instructions. After seeding the cells into 96 -well plates at a concentration of $2 \sim 5 \times 10^{3}$ cells per well, serial dilutions of compounds were added and cultured for $72 \mathrm{~h}$. Then, MTT solution $(5 \mathrm{mg} / \mathrm{mL}$ in PBS) was 
added and incubated at $37^{\circ} \mathrm{C}$ for $4 \mathrm{~h}$. After adding $150 \mu \mathrm{L}$ DMSO followed by removing the MTT, the plate was measured at the absorbance of $490 \mathrm{~nm}$. The data were analyzed using SPSS 20 software.

Colony Formation Assay. Firstly, H1975, PC9 and A549 cells were seeded at a concentration of $1 \times 10^{3}$ cells per well and cultured overnight. Then, the fresh medium was added with compound DC-2 into the wells. After 7 days' incubation, the cells were fixed and stained by $0.1 \%$ crystal violet solution and then imaged by microscopy (Nikon). Subsequently, the crystal violet crystals were dissolved and measured by a BioTek microplate reader. The data were analyzed using the GraphPad Prism 5 software.

Analysis of Cellular Apoptosis. For the analysis of apoptosis by flow cytometry. Firstly, H1975, PC9 and A549 cells were seeded into 6-well plates $\left(1 \sim 2 \times 10^{6}\right.$ cells $\left./ \mathrm{mL}\right)$ and incubated overnight. Then, compound DC-2 at 0, 2.5, 5 and $10 \mu \mathrm{M}$ were added. After treatment for $48 \mathrm{~h}$, the cells were harvested and stained using the Annexin-V-FITC/PI apoptosis kit for 30 minutes. Then, the cells were collected and measured by FACSCalibur flow cytometer (BD Biosciences). All data were analyzed by FlowJo-V10 and GraphPad Prism 5 software.

Western Blot Analysis. H1975 and PC9 cells were seeded in $100 \mathrm{~mm}^{2}$ plastic dishes $\left(1 \times 10^{6}\right.$ cells/well) and incubated overnight prior to the addition of compound DC-2 at $0,0.3,1,10$ and $20 \mu \mathrm{M}$ for $24 \mathrm{~h}$. Then, the cells were harvested, lysed and centrifuged at $12,000 \times \mathrm{g}$ for 20 minutes at $4{ }^{\circ} \mathrm{C}$. The supernatant were determined by BCA Protein Assay kit, denatured at $100^{\circ} \mathrm{C}$ for $10 \mathrm{~min}$ and incubated at $-20^{\circ} \mathrm{C}$ for Western Blot. After separated by SDS-PAGE, the protein were transferred to $0.22 \mu \mathrm{m}$ nitrocellulose membranes and blocked by $5 \%$ skim milk. Then, the membranes were probed with appropriate primary antibodies and incubated at $4{ }^{\circ} \mathrm{C}$ overnight, 
followed by the treatment of horseradish-peroxidase-conjugated secondary antibody (1:10000). Subsequently, the membranes were washed with PBST and examined by enhanced chemiluminescence. The data was determined and analyzed using Image $\mathrm{J}$ software and GraphPad Prism 5 software.

Water Solubility Assay. Water solubility assay was performed as previous described. ${ }^{30,73}$ Briefly, compound DC-2 was added as powder into an Eppendorf tube, which was full of phosphate buffer (PBS, pH 7.4), until heterogeneous suspension was obtained. Then, the suspension was sonicated in a water bath for $30 \mathrm{~min}$ and shaken for $24 \mathrm{~h}$ at room temperature until reaching thermodynamic equilibrium. Suspensions were then centrifuged at 12000r for 15 min and the supernatants were filtered, using $0.45 \mu \mathrm{m}$ membrane. PBS was used as a control. The filtrate was measured by UV-2700 spectroscopy (Shimadzu, Japan).

siRNA Experiments. Cells were seeded in 6-well plates for 16-24h before siRNA treatment. Then, medium was taken away and the cells were transfected with siRNA using Lipofectamine ${ }^{\circledR}$ RNAiMAX Reagent according to manufacturer's instructions. Three days later, the cells were collected and used for Western Blot assay. Three different siRNA duplexes targeting three specific sequences of DCN1 and a negative control siRNA were synthesized by GenePharma(Shanghai, China). The sense strand nucleotide sequence for DCN1 \#1 siRNA was 5'-GGAUAAAGUUCGUCAGUUUTT-3', and the anti-sense sequence was 5'AAACUGACGAACUUUAUCCTT-3'; DCN1 \#2 siRNA was 5'GGACAGGAAGAAGUUAGAATT-3', and the anti-sense sequence was 5'UUCUAACUUCUUCCUGUCCTT-3'; DCN1 \#3 siRNA was 5'GCCAUUGCCUACUGGAACUTT-3', and the anti-sense sequence was 5'- 
AGUUCCAGUAGGCAAUGGCTT-3'. The negative control siRNA (siNeg) sense sequence was 5'-UUCUCCGAACGUGUCACGUTT-3', while the anti-sense sequence was 5'ACGUGACACGUUCGGAGAATT-3'.

Statistical Analysis. Data were expressed as mean \pm SD. Statistical differences in two groups were performed by student's $t$-test using GraphPad Prism 5 software. One-way ANOVA analysis was used for multiple group comparison by SPSS 20 software. P-values of 0.05 or less were considered statistically significant.

\section{- AUTHOR INFORMATION}

\section{Corresponding Authors}

*Wen Zhao, Email: zhaowen100@139.com, zhaowen@zzu.edu.cn; Phone, 86-15003898187

*Zhenhe Suo, Email: zhenhe.suo@medisin.uio.no; Phone, 47-98280093

*Hongmin Liu, Email: liuhm@zzu.edu.cn; Phone, 86-371-67781739.

\section{ORCID}

Wen Zhao: 0000-0002-2530-7637

Hongmin Liu: 0000-0001-6771-9421

\section{Author Contributions}

\#Wenjuan Zhou and Liying Ma contribute equally to this work.

\section{Notes:}

The authors declare no competing financial interest.

\section{- ACKNOWLEDGMENTS}

We thank Dr. Brenda A Schulman (Department of Structural Biology and Howard Hughes 
Medical Institute, St. Jude Children's Research Hospital, Memphis, Tennessee, USA) and Dr.

R Kip Guy's group (Department of Pharmaceutical Sciences, University of Kentucky, Lexington, Kentucky, USA) for providing the compounds: NAcM-COV, NAcM-OPT and

\section{NAcM-NEG.}

This work was supported by National Key Grant from Chinese Ministry of Science and Technology (2016YFA0501800 by Z.W), National Natural Science Foundation of China (NO. 81470524 and 81870297 by Z.W; NO. 81430085 by L.H-M; 81703328 by M. L-Y) and Henan Scientific Innovation Talent Team, Department of Education (19IRTSTHN001 by Z.W); the Starting Grant of Zhengzhou University (Grant 32210535 by M. L-Y); Scientific Program of Henan Province (Grant 182102310070 by M. L-Y).

\section{- ABBREVIATIONS USED}

DCN1, defective in cullin neddylation 1; UBE2M, NEDD8-conjugating enzyme Ubc12; SCC, squamous cell carcinoma; CRL, cullin ring ligases; NEDD8, neural precursor cell expressed, developmentally down-regulated 8; NAE, NEDD8-activating enzyme; RBX1, ringbox 1; E3, ubiquitin protein ligase; CUL1, cullin 1; CUL2, cullin2; CUL3, cullin3; CUL4, cullin4; CUL5, cullin5; MTT, 3-(4,5-dimethylthiazol-2-yl)-2,5-diphenyltetrazolium bromide; CETSA, Cellular thermal shift assay; FP, fluorescence polarization; IPTG, isopropyl- $\beta$-Dgalactopyranoside; HTRF, Homogeneous Time-Resolved Fluorescence; NRF2, the nuclear factor-erythroid 2 related factor 2; SAR, structure-activity relationship; NQO1, NADPH: quinone oxidoreductase-1; HO-1, Heme oxygenase-1.

\section{- ASSOCIATED CONTENT}


Supporting Information. The Supporting Information is available free of charge on the ACS

Publications website at DOI: XXXX

Molecular formula strings (CSV)

The purities and abundances of all the recombinant proteins; The direct interaction of Biotin-AcUBE2M $\mathrm{M}^{1-21}$ peptides with wild type DCN1 (GST-DCN1) and its mutants (P97T, F164S and Y181I); Solubility of compound DC-2 and HPLC spectra of representative compounds (PDF)

Coordinates of modeled structures of compound DC-2 in complex with DCN1 after molecular dynamics simulations (PDB code: 3TDU). Authors will release the atomic coordinates and experimental data upon article publication.

\section{REFERENCES:}

(1) Hicke, L. Protein regulation by monoubiquitin. Nat. Rev. Mol. Cell Biol. 2001, 2, 195201.

(2) Kerscher, O.; Felberbaum, R.; Hochstrasser, M. Modification of proteins by ubiquitin and ubiquitin-like proteins. Annu. Rev. Cell Dev. Biol. 2006, 22, 159-180.

(3) Mukhopadhyay, D.; Riezman, H. Proteasome-independent functions of ubiquitin in endocytosis and signaling. Science 2007, 315, 201-205.

(4) Aguilar, R. C.; Wendland, B. Ubiquitin: not just for proteasomes anymore. Curr. Opin. Cell Biol. 2003, 15, 184-190.

(5) Nalepa, G.; Rolfe, M.; Harper, J. W. Drug discovery in the ubiquitin-proteasome system. Nat. Rev. Drug Discov. 2006, 5, 596-613.

(6) Zhong, H. J.; Leung, K. H.; Lin, S.; Chan, D. S.; Han, Q. B.; Chan, S. L.; Ma, D. L.; 
Leung, C. H. Discovery of deoxyvasicinone derivatives as inhibitors of NEDD8-activating enzyme. Methods 2015, 71, 71-76.

(7) Brownell, J. E.; Sintchak, M. D.; Gavin, J. M.; Liao, H.; Bruzzese, F. J.; Bump, N. J.; Soucy, T. A.; Milhollen, M. A.; Yang, X.; Burkhardt, A. L.; Ma, J.; Loke, H. K.; Lingaraj, T.; Wu, D.; Hamman, K. B.; Spelman, J. J.; Cullis, C. A.; Langston, S. P.; Vyskocil, S.; Sells, T. B.; Mallender, W. D.; Visiers, I.; Li, P.; Claiborne, C. F.; Rolfe, M.; Bolen, J. B.; Dick, L. R. Substrate-assisted inhibition of ubiquitin-like protein-activating enzymes: the NEDD8 E1 inhibitor MLN4924 forms a NEDD8-AMP mimetic in situ. Mol. Cell 2010, 37, 102-111.

(8) Tanaka, K.; Suzuki, T.; Chiba, T. The ligation systems for ubiquitin and ubiquitin-like proteins. Mol. Cell 1998, 8, 503-512.

(9) Zhao, Y.; Morgan, M. A.; Sun, Y. Targeting neddylation pathways to inactivate cullinRING ligases for anticancer therapy. Antioxid Redox Signal 2014, 21, 2383-2400.

(10) Soucy, T. A.; Smith, P. G.; Milhollen, M. A.; Berger, A. J.; Gavin, J. M.; Adhikari, S.; Brownell, J. E.; Burke, K. E.; Cardin, D. P.; Critchley, S.; Cullis, C. A.; Doucette, A.; Garnsey, J. J.; Gaulin, J. L.; Gershman, R. E.; Lublinsky, A. R.; McDonald, A.; Mizutani, H.; Narayanan, U.; Olhava, E. J.; Peluso, S.; Rezaei, M.; Sintchak, M. D.; Talreja, T.; Thomas, M. P.; Traore, T.; Vyskocil, S.; Weatherhead, G. S.; Yu, J.; Zhang, J.; Dick, L. R.; Claiborne, C. F.; Rolfe, M.; Bolen, J. B.; Langston, S. P. An inhibitor of NEDD8-activating enzyme as a new approach to treat cancer. Nature 2009, 458, 732-736.

(11) Osaka, F.; Saeki, M.; Katayama, S.; Aida, N.; Toh, E. A.; Kominami, K.; Toda, T.; Suzuki, T.; Chiba, T.; Tanaka, K.; Kato, S. Covalent modifier NEDD8 is essential for SCF ubiquitin-ligase in fission yeast. EMBO J. 2000, 19, 3475-3484. 
(12) Duda, D. M.; Borg, L. A.; Scott, D. C.; Hunt, H. W.; Hammel, M.; Schulman, B. A. Structural insights into NEDD8 activation of cullin-RING ligases: conformational control of conjugation. Cell 2008, 134, 995-1006.

(13) Hori, T.; Osaka, F.; Chiba, T.; Miyamoto, C.; Okabayashi, K.; Shimbara, N.; Kato, S.; Tanaka, K. Covalent modification of all members of human cullin family proteins by NEDD8. Oncogene 1999, 18, 6829-6834.

(14) Kawakami, T.; Chiba, T.; Suzuki, T.; Iwai, K.; Yamanaka, K.; Minato, N.; Suzuki, H.; Shimbara, N.; Hidaka, Y.; Osaka, F.; Omata, M.; Tanaka, K. NEDD8 recruits E2-ubiquitin to SCF E3 ligase. EMBO J. 2001, 20, 4003-4012.

(15) Morimoto, M.; Nishida, T.; Honda, R.; Yasuda, H. Modification of cullin-1 by ubiquitin-like protein Nedd8 enhances the activity of SCF(skp2) toward p27(kip1). Biochem. Biophys. Res. Commun. 2000, 270, 1093-1096.

(16) Morimoto, M.; Nishida, T.; Nagayama, Y.; Yasuda, H. Nedd8-modification of Cul1 is promoted by Roc1 as a Nedd8-E3 ligase and regulates its stability. Biochem. Biophys. Res. Commun. 2003, 301, 392-398.

(17) Ohh, M.; Kim, W. Y.; Moslehi, J. J.; Chen, Y.; Chau, V.; Read, M. A.; Kaelin, W. G., Jr. An intact NEDD8 pathway is required for Cullin-dependent ubiquitylation in mammalian cells. Embo. Rep. 2002, 3, 177-182.

(18) Pan, Z. Q.; Kentsis, A.; Dias, D. C.; Yamoah, K.; Wu, K. Nedd8 on cullin: building an expressway to protein destruction. Oncogene 2004, 23, 1985-1997.

(19) Parry, G.; Estelle, M. Regulation of cullin-based ubiquitin ligases by the Nedd8/RUB ubiquitin-like proteins. Semin. Cell Dev. Biol. 2004, 15, 221-229. 
(20) Saha, A.; Deshaies, R. J. Multimodal activation of the ubiquitin ligase SCF by Nedd8 conjugation. Mol. Cell 2008, 32, 21-31.

(21) Scott, D. C.; Sviderskiy, V. O.; Monda, J. K.; Lydeard, J. R.; Cho, S. E.; Harper, J. W.; Schulman, B. A. Structure of a RING E3 trapped in action reveals ligation mechanism for the ubiquitin-like protein NEDD8. Cell 2014, 157, 1671-1684.

(22) Nawrocki, S. T.; Griffin, P.; Kelly, K. R.; Carew, J. S. MLN4924: a novel first-in-class inhibitor of NEDD8-activating enzyme for cancer therapy. Expert Opin. Investig. Drugs 2012, 21, 1563-1573.

(23) Ciechanover, A. Intracellular protein degradation: from a vague idea through the lysosome and the ubiquitin-proteasome system and onto human diseases and drug targeting. Bioorg. Med. Chem. 2013, 21, 3400-3410.

(24) Bassermann, F.; Eichner, R.; Pagano, M. The ubiquitin proteasome system implications for cell cycle control and the targeted treatment of cancer. Biochim. Biophys. Acta. 2014, 1843, 150-162.

(25) Wei, D.; Li, H.; Yu, J.; Sebolt, J. T.; Zhao, L.; Lawrence, T. S.; Smith, P. G.; Morgan, M. A.; Sun, Y. Radiosensitization of human pancreatic cancer cells by MLN4924, an investigational NEDD8-activating enzyme inhibitor. Cancer Res. 2012, 72, 282-293.

(26) Tanaka, T.; Nakatani, T.; Kamitani, T. Inhibition of NEDD8-conjugation pathway by novel molecules: potential approaches to anticancer therapy. Mol. Oncol. 2012, 6, 267-275.

(27) Godbersen, J. C.; Humphries, L. A.; Danilova, O. V.; Kebbekus, P. E.; Brown, J. R.; Eastman, A.; Danilov, A. V. The Nedd8-activating enzyme inhibitor MLN4924 thwarts microenvironment-driven NF-kappaB activation and induces apoptosis in chronic lymphocytic 
leukemia B cells. Clin. Cancer Res. 2014, 20, 1576-1589.

(28) Khalife, J.; Radomska, H. S.; Santhanam, R.; Huang, X.; Neviani, P.; Saultz, J.; Wang, H.; Wu, Y. Z.; Alachkar, H.; Anghelina, M.; Dorrance, A.; Curfman, J.; Bloomfield, C. D.; Medeiros, B. C.; Perrotti, D.; Lee, L. J.; Lee, R. J.; Caligiuri, M. A.; Pichiorri, F.; Croce, C. M.; Garzon, R.; Guzman, M. L.; Mendler, J. H.; Marcucci, G. Pharmacological targeting of miR155 via the NEDD8-activating enzyme inhibitor MLN4924 (Pevonedistat) in FLT3-ITD acute myeloid leukemia. Leukemia 2015, 29, 1981-1992.

(29) Swords, R. T.; Erba, H. P.; DeAngelo, D. J.; Bixby, D. L.; Altman, J. K.; Maris, M.; Hua, Z.; Blakemore, S. J.; Faessel, H.; Sedarati, F.; Dezube, B. J.; Giles, F. J.; Medeiros, B. C. Pevonedistat (MLN4924), a First-in-Class NEDD8-activating enzyme inhibitor, in patients with acute myeloid leukaemia and myelodysplastic syndromes: a phase 1 study. Br. J. Haematol. 2015, 169, 534-543.

(30) Zhou, H.; Lu, J.; Liu, L.; Bernard, D.; Yang, C. Y.; Fernandez-Salas, E.; Chinnaswamy, K.; Layton, S.; Stuckey, J.; Yu, Q.; Zhou, W.; Pan, Z.; Sun, Y.; Wang, S. A potent small-molecule inhibitor of the DCN1-UBC12 interaction that selectively blocks cullin 3 neddylation. Nat. Commun. 2017, 8, 1150.

(31) Hammill, J. T.; Scott, D. C.; Min, J.; Connelly, M. C.; Holbrook, G.; Zhu, F.; Matheny, A.; Yang, L.; Singh, B.; Schulman, B. A.; Guy, R. K. Piperidinyl ureas chemically control defective in cullin neddylation 1 (DCN1)-mediated cullin neddylation. J. Med. Chem. 2018, 61, 2680-2693.

(32) Zhou, H.; Zhou, W.; Zhou, B.; Liu, L.; Chern, T. R.; Chinnaswamy, K.; Lu, J.; Bernard, D.; Yang, C. Y.; Li, S.; Wang, M.; Stuckey, J.; Sun, Y.; Wang, S. High-affinity peptidomimetic 
inhibitors of the DCN1-UBC12 protein-protein interaction. J. Med. Chem. 2018, 61, 1934-1950.

(33) Sarkaria, I.; P, O. c.; Talbot, S. G.; Reddy, P. G.; Ngai, I.; Maghami, E.; Patel, K. N.; Lee, B.; Yonekawa, Y.; Dudas, M.; Kaufman, A.; Ryan, R.; Ghossein, R.; Rao, P. H.; Stoffel, A.; Ramanathan, Y.; Singh, B. Squamous cell carcinoma related oncogene/DCUN1D1 is highly conserved and activated by amplification in squamous cell carcinomas. Cancer Res. 2006, 66, 9437-9444.

(34) Estilo, C. L.; P, O. C.; Ngai, I.; Patel, S. G.; Reddy, P. G.; Dao, S.; Shaha, A. R.; Kraus, D. H.; Boyle, J. O.; Wong, R. J.; Pfister, D. G.; Huryn, J. M.; Zlotolow, I. M.; Shah, J. P.; Singh, B. The role of novel oncogenes squamous cell carcinoma-related oncogene and phosphatidylinositol 3-kinase p110alpha in squamous cell carcinoma of the oral tongue. Clin. Cancer Res. 2003, 9, 2300-2306.

(35) P, O. c.; Sarkaria, I.; Talbot, S. G.; Reddy, P.; Dao, S.; Ngai, I.; Shaha, A.; Kraus, D.; Shah, J.; Rusch, V.; Ramanathan, Y.; Singh, B. SCCRO (DCUN1D1) induces extracellular matrix invasion by activating matrix metalloproteinase 2. Clin. Cancer Res. 2008, 14, 67806789.

(36) Talbot, S. G.; P, O. c.; Sarkaria, I. S.; Ghossein, R.; Reddy, P.; Ngai, I.; Cordeiro, C. N.; Wong, R. J.; Kris, M. G.; Rusch, V. W.; Singh, B. Squamous cell carcinoma related oncogene regulates angiogenesis through vascular endothelial growth factor-A. Ann. Surg. Oncol. 2004, $11,530-534$

(37) Huang, G.; Singh, B. Coamplification and cooperation: toward identifying biologically relevant oncogenes. Clin. Cancer Res. 2013, 19, 5549-5551.

(38) Wang, J.; Qian, J.; Hoeksema, M. D.; Zou, Y.; Espinosa, A. V.; Rahman, S. M.; Zhang, 
B.; Massion, P. P. Integrative genomics analysis identifies candidate drivers at 3q26-29 amplicon in squamous cell carcinoma of the lung. Clin. Cancer Res. 2013, 19, 5580-5590.

(39) Chen, Y.; McGee, J.; Chen, X.; Doman, T. N.; Gong, X.; Zhang, Y.; Hamm, N.; Ma, X.;

Higgs, R. E.; Bhagwat, S. V.; Buchanan, S.; Peng, S. B.; Staschke, K. A.; Yadav, V.; Yue, Y.; Kouros-Mehr, H. Identification of druggable cancer driver genes amplified across TCGA datasets. PLoS One 2014, 9, e98293.

(40) Kurz, T.; Chou, Y. C.; Willems, A. R.; Meyer-Schaller, N.; Hecht, M. L.; Tyers, M.; Peter, M.; Sicheri, F. Dcn1 functions as a scaffold-type E3 ligase for cullin neddylation. Mol. Cell 2008, 29, 23-35.

(41) Kurz, T.; Ozlu, N.; Rudolf, F.; O'Rourke, S. M.; Luke, B.; Hofmann, K.; Hyman, A. A.; Bowerman, B.; Peter, M. The conserved protein $\mathrm{DCN}-1 / \mathrm{Dcn} 1 \mathrm{p}$ is required for cullin neddylation in C. elegans and S. cerevisiae. Nature 2005, 435, 1257-1261.

(42) Kim, A. Y.; Bommelje, C. C.; Lee, B. E.; Yonekawa, Y.; Choi, L.; Morris, L. G.; Huang, G.; Kaufman, A.; Ryan, R. J.; Hao, B.; Ramanathan, Y.; Singh, B. SCCRO (DCUN1D1) is an essential component of the E3 complex for neddylation. J. Biol. Chem. 2008, 283, 33211-33220.

(43) Scott, D. C.; Hammill, J. T.; Min, J.; Rhee, D. Y.; Connelly, M.; Sviderskiy, V. O.; Bhasin, D.; Chen, Y.; Ong, S. S.; Chai, S. C.; Goktug, A. N.; Huang, G.; Monda, J. K.; Low, J.; Kim, H. S.; Paulo, J. A.; Cannon, J. R.; Shelat, A. A.; Chen, T.; Kelsall, I. R.; Alpi, A. F.; Pagala, V.; Wang, X.; Peng, J.; Singh, B.; Harper, J. W.; Schulman, B. A.; Guy, R. K. Blocking an Nterminal acetylation-dependent protein interaction inhibits an E3 ligase. Nat. Chem. Biol. 2017, $13,850-857$.

(44) Sarkaria, I. S.; Pham, D.; Ghossein, R. A.; Talbot, S. G.; Hezel, M.; Dudas, M. E.; 
Ebright, M. I.; Chuai, S.; Memoli, N.; Venkatraman, E. S.; Miller, V. A.; Kris, M. G.; Zakowski, M. F.; Rusch, V. W.; Singh, B. SCCRO expression correlates with invasive progression in bronchioloalveolar carcinoma. Ann. Thorac. Surg. 2004, 78, 1734-1741.

(45) Meyer-Schaller, N.; Chou, Y. C.; Sumara, I.; Martin, D. D.; Kurz, T.; Katheder, N.; Hofmann, K.; Berthiaume, L. G.; Sicheri, F.; Peter, M. The human Den1-like protein DCNL3 promotes Cul3 neddylation at membranes. Proc. Natl. Acad. Sci. US A 2009, 106, 12365-12370.

(46) Singh, B.; Gogineni, S. K.; Sacks, P. G.; Shaha, A. R.; Shah, J. P.; Stoffel, A.; Rao, P. H. Molecular cytogenetic characterization of head and neck squamous cell carcinoma and refinement of 3q amplification. Cancer Res. 2001, 61, 4506-4513.

(47) Zhang, Q.; Pi, J.; Woods, C. G.; Andersen, M. E. A systems biology perspective on Nrf2-mediated antioxidant response. Toxicol. Appl. Pharmacol. 2010, 244, 84-97.

(48) Broderick, S. R.; Golas, B. J.; Pham, D.; Towe, C. W.; Talbot, S. G.; Kaufman, A.; Bains, S.; Huryn, L. A.; Yonekawa, Y.; Carlson, D.; Hambardzumyan, D.; Ramanathan, Y.; Singh, B. SCCRO promotes glioma formation and malignant progression in mice. Neoplasia 2010, 12, 476-484.

(49) Jiang, Z.; Song, Q.; Zeng, R.; Li, J.; Li, J.; Lin, X.; Chen, X.; Zhang, J.; Zheng, Y. MicroRNA-218 inhibits EMT, migration and invasion by targeting SFMBT1 and DCUN1D1 in cervical cancer. Oncotarget 2016, 7, 45622-45636.

(50) Shuang, Y.; Li, C.; Zhou, X.; Huang, Y.; Zhang, L. MicroRNA-195 inhibits growth and invasion of laryngeal carcinoma cells by directly targeting DCUN1D1. Oncol. Rep. 2017, 38, 2155-2165.

(51) Xiao, J.; Li, G.; Zhou, J.; Wang, S.; Liu, D.; Shu, G.; Zhou, J.; Ren, F. MicroRNA-520b 
functions as a tumor suppressor in colorectal cancer by inhibiting defective in cullin neddylation 1 domain containing 1 (DCUN1D1). Oncol. Res. 2018, 26, 593-604.

(52) Scott, D. C.; Monda, J. K.; Bennett, E. J.; Harper, J. W.; Schulman, B. A. N-terminal acetylation acts as an avidity enhancer within an interconnected multiprotein complex. Science 2011, 334, 674-678.

(53) Fleury, L.; Faux, C.; Santos, C.; Ballereau, S.; Genisson, Y.; Ausseil, F. Development of a CERT START domain-ceramide HTRF binding assay and application to pharmacological studies and screening. J. Biomol. Screen 2015, 20, 779-787.

(54) Ma, L. Y.; Zheng, Y. C.; Wang, S. Q.; Wang, B.; Wang, Z. R.; Pang, L. P.; Zhang, M.; Wang, J. W.; Ding, L.; Li, J.; Wang, C.; Hu, B.; Liu, Y.; Zhang, X. D.; Wang, J. J.; Wang, Z. J.; Zhao, W.; Liu, H. M. Design, synthesis, and structure-activity relationship of novel LSD1 inhibitors based on pyrimidine-thiourea hybrids as potent, orally active antitumor agents. $J$. Med. Chem. 2015, 58, 1705-1716.

(55) Monda, J. K.; Scott, D. C.; Miller, D. J.; Lydeard, J.; King, D.; Harper, J. W.; Bennett, E. J.; Schulman, B. A. Structural conservation of distinctive N-terminal acetylation-dependent interactions across a family of mammalian NEDD8 ligation enzymes. Structure 2013, 21, 4253.

(56) Almqvist, H.; Axelsson, H.; Jafari, R.; Dan, C.; Mateus, A.; Haraldsson, M.; Larsson, A.; Martinez Molina, D.; Artursson, P.; Lundback, T.; Nordlund, P. CETSA screening identifies known and novel thymidylate synthase inhibitors and slow intracellular activation of 5fluorouracil. Nat. Commun. 2016, 7, 11040.

(57) Fu, X.; Wang, Z.; Li, L.; Dong, S.; Li, Z.; Jiang, Z.; Wang, Y.; Shui, W. Novel chemical 
ligands to ebola virus and marburg virus nucleoproteins identified by combining affinity mass spectrometry and metabolomics approaches. Sci. Rep. 2016, 6, 29680.

(58) Villa, C.; Venturelli, E.; Fenoglio, C.; Clerici, F.; Marcone, A.; Benussi, L.; Gallone, S.; Scalabrini, D.; Cortini, F.; Serpente, M.; Martinelli Boneschi, F.; Cappa, S.; Binetti, G.; Mariani, C.; Rainero, I.; Giordana, M. T.; Bresolin, N.; Scarpini, E.; Galimberti, D. DCUN1D1 is a risk factor for frontotemporal lobar degeneration. Eur. J. Neurol. 2009, 16, 870-873.

(59) Ma, T.; Shi, T.; Huang, J.; Wu, L.; Hu, F.; He, P.; Deng, W.; Gao, P.; Zhang, Y.; Song, Q.; Ma, D.; Qiu, X. DCUN1D3, a novel UVC-responsive gene that is involved in cell cycle progression and cell growth. Cancer Sci. 2008, 99, 2128-2135.

(60) Keuss, M. J.; Thomas, Y.; McArthur, R.; Wood, N. T.; Knebel, A.; Kurz, T. Characterization of the mammalian family of DCN-type NEDD8 E3 ligases. J. Cell Sci. 2016, $129,1441-1454$.

(61) Huang, D. T.; Miller, D. W.; Mathew, R.; Cassell, R.; Holton, J. M.; Roussel, M. F.; Schulman, B. A. A unique E1-E2 interaction required for optimal conjugation of the ubiquitinlike protein NEDD8. Nat. Struct. Mol. Biol. 2004, 11, 927-935.

(62) Scott, D. C.; Monda, J. K.; Grace, C. R.; Duda, D. M.; Kriwacki, R. W.; Kurz, T.; Schulman, B. A. A dual E3 mechanism for Rub1 ligation to Cdc53. Mol. Cell 2010, 39, 784796.

(63) Kobayashi, A.; Kang, M. I.; Okawa, H.; Ohtsuji, M.; Zenke, Y.; Chiba, T.; Igarashi, K.; Yamamoto, M. Oxidative stress sensor Keap1 functions as an adaptor for Cul3-based E3 ligase to regulate proteasomal degradation of Nrf2. Mol. Cell Biol. 2004, 24, 7130-7139.

(64) Cullinan, S. B.; Gordan, J. D.; Jin, J.; Harper, J. W.; Diehl, J. A. The Keap1-BTB protein 
is an adaptor that bridges Nrf2 to a Cul3-based E3 ligase: oxidative stress sensing by a Cul3Keap1 ligase. Mol. Cell Biol. 2004, 24, 8477-8486.

(65) Venugopal, R.; Jaiswal, A. K. Nrf2 and Nrf1 in association with Jun proteins regulate antioxidant response element-mediated expression and coordinated induction of genes encoding detoxifying enzymes. Oncogene 1998, 17, 3145-3156.

(66) Nishitani, H.; Sugimoto, N.; Roukos, V.; Nakanishi, Y.; Saijo, M.; Obuse, C.; Tsurimoto, T.; Nakayama, K. I.; Nakayama, K.; Fujita, M.; Lygerou, Z.; Nishimoto, T. Two E3 ubiquitin ligases, SCF-Skp2 and DDB1-Cul4, target human Cdt1 for proteolysis. EMBO J. 2006, 25, 1126-1136.

(67) Gorrini, C.; Harris, I. S.; Mak, T. W. Modulation of oxidative stress as an anticancer strategy. Nat. Rev. Drug Discov. 2013, 12, 931-947.

(68) Ma, Q. Role of nrf2 in oxidative stress and toxicity. Annu. Rev. Pharmacol. Toxicol. 2013, 53, 401-426.

(69) Lydeard, J. R.; Harper, J. W. Inhibitors for E3 ubiquitin ligases. Nat. Biotechnol. 2010, $28,682-684$.

(70) Baell, J. B.; Holloway, G. A. New substructure filters for removal of pan assay interference compounds (PAINS) from screening libraries and for their exclusion in bioassays. J. Med. Chem. 2010, 53, 2719-2740.

(71) Ma, L. Y.; Pang, L. P.; Wang, B.; Zhang, M.; Hu, B.; Xue, D. Q.; Shao, K. P.; Zhang, B. L.; Liu, Y.; Zhang, E.; Liu, H. M. Design and synthesis of novel 1,2,3-triazole-pyrimidine hybrids as potential anticancer agents. Eur. J. Med. Chem. 2014, 86, 368-380.

(72) Ma, L. Y.; Wang, B.; Pang, L. P.; Zhang, M.; Wang, S. Q.; Zheng, Y. C.; Shao, K. P.; 
Xue, D. Q.; Liu, H. M. Design and synthesis of novel 1,2,3-triazole-pyrimidine-urea hybrids as potential anticancer agents. Bioorg. Med. Chem. Lett. 2015, 25, 1124-1128.

(73) Wang, B.; Ma, L. Y.; Wang, J. Q.; Lei, Z. N.; Gupta, P.; Zhao, Y. D.; Li, Z. H.; Liu, Y.; Zhang, X. H.; Li, Y. N.; Zhao, B.; Chen, Z. S.; Liu, H. M. Discovery of 5-cyano-6phenylpyrimidin derivatives containing an acylurea moiety as orally bioavailable reversal agents against p-glycoprotein-mediated mutidrug resistance. J. Med. Chem. 2018, 61, 59886001.

(74) Nikolovska-Coleska, Z.; Wang, R.; Fang, X.; Pan, H.; Tomita, Y.; Li, P.; Roller, P. P.; Krajewski, K.; Saito, N. G.; Stuckey, J. A.; Wang, S. Development and optimization of a binding assay for the XIAP BIR3 domain using fluorescence polarization. Anal Biochem. 2004, $332,261-273$.

(75) Martinez Molina, D.; Jafari, R.; Ignatushchenko, M.; Seki, T.; Larsson, E. A.; Dan, C.; Sreekumar, L.; Cao, Y.; Nordlund, P. Monitoring drug target engagement in cells and tissues using the cellular thermal shift assay. Science 2013, 341, 84-87.

(76) Zhong, H. J.; Wang, W.; Kang, T. S.; Yan, H.; Yang, Y.; Xu, L.; Wang, Y.; Ma, D. L.; Leung, C. H. A rhodium(III) complex as an inhibitor of neural precursor cell expressed, developmentally down-regulated 8-activating enzyme with in vivo activity against inflammatory bowel disease. J. Med. Chem. 2017, 60, 497-503.

(77) Lee, M. M.; Peterson, B. R. Quantification of small molecule-protein interactions using FRET between tryptophan and the pacific blue fluorophore. ACS Omega 2016, 1, 1266-1276. 


\title{
Supporting Information
}

\section{Potent 5-Cyano-6-Phenyl-Pyrimidin-Based Derivatives Targeting DCN1-UBE2M Interaction}

\author{
Wenjuan Zhou, ${ }^{\dagger,}, \#$, Liying Ma ${ }^{\dagger, \#}$, Lina Ding ${ }^{\dagger}$, Qian Guo ${ }^{\dagger}$, Zhangxu $\mathrm{He}^{\dagger}$, Jing Yang ${ }^{\dagger}$, Hui \\ $\mathrm{Qiao}^{\dagger}$, Lingyu $\mathrm{Li}^{\dagger}$, Jie Yang ${ }^{\dagger}$, Shimin $\mathrm{Yu}^{\dagger}$, Lili Zhao ${ }^{\dagger}$, Shaomeng Wang ${ }^{\dagger, \S}$, \\ Hong-Min $\operatorname{Liu}^{\dagger} *$, Zhenhe Suo ${ }^{\ddagger} *$, Wen Zhao ${ }^{\dagger * *}$
}

'State Key Laboratory of Esophageal Cancer Prevention and Treatment; Key Laboratory of Advanced Pharmaceutical Technology, Ministry of Education of China; School of Pharmaceutical Sciences, Zhengzhou University, 100 Kexue Avenue, Zhengzhou, Henan, 450001, China

Department of Pathology, Oslo Univers ity Hospital; Faculty of Medic ine, University of Oslo, Oslo, 0379, Norway

${ }^{\S}$ The Rogel Cancer Center and Departments of Internal Medicine, Pharmacology, Medicinal Chemistry and Pathology, University of Michigan Medical School, Ann Arbor, Michigan, 48109, United States

\#: Both authors contribute equally to this work.

*: These senior authors contribute equally to this work.

${ }^{*}$ : Corresponding to:

Wen Zhao, Email: zhaowen100@139.com, zhaowen@,zzu.edu.cn; Phone, 86-15003898187

Zhenhe Suo, Email: zhenhe.suo@medisin.uio.no; Phone, 47-98280093

Hongmin Liu, Email: liuhm@zzu.edu.cn; Phone, 86-371-67781739. 


\section{Table of Contents:}

Figure S1. The purities and abundances of all the recombinant proteins......................... S2

Figure S2. Solubility of compound DC-2 in phosphate buffer........................................... S2

Figure S3. The direct interaction of Biotin-AcUBE2 $M^{1-21}$ peptides with wild type DCN1(GST-DCN1) and its mutants(P97T, F164S and Y181I).

A

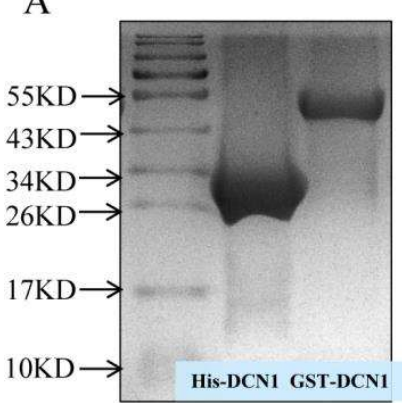

B

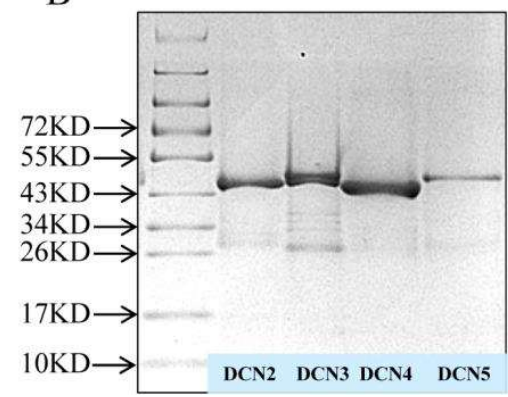

$\mathrm{C}$

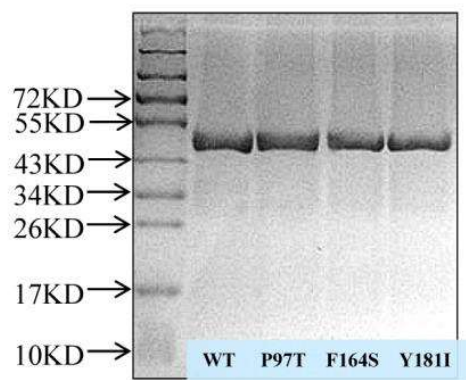

Figure S1. The purities and abundances of all the recombinant proteins. (A) His-tagged DCN1, GST-tagged DCN1, (B) DCN2, DCN3, DCN4, DCN5, (C) DCN1(Wild type, WT), DCN1-P97T, DCN1-F164S and DCN1-Y181I were determined by SDS-PAGE and Commassie Blue staining.

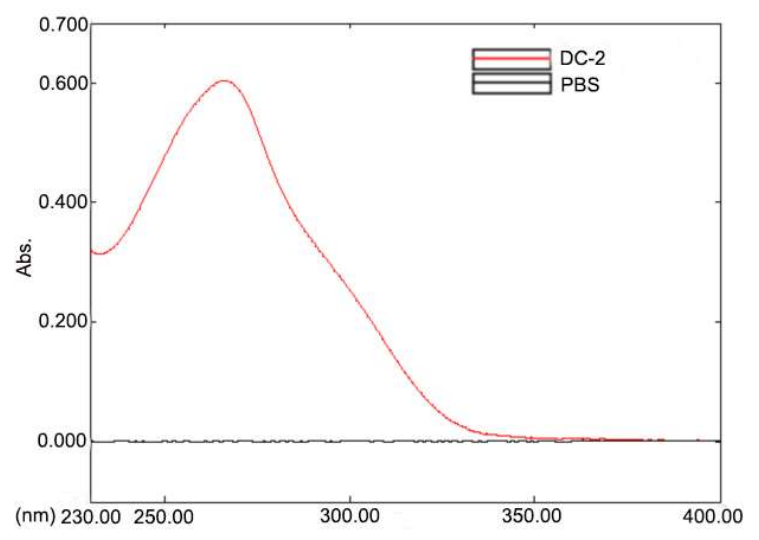

Figure S2. Solubility of compound DC-2 in phos phate buffer. UV-V is absorption spectra of compound DC-2 at $\mathrm{pH}$ value 7.4. 
A

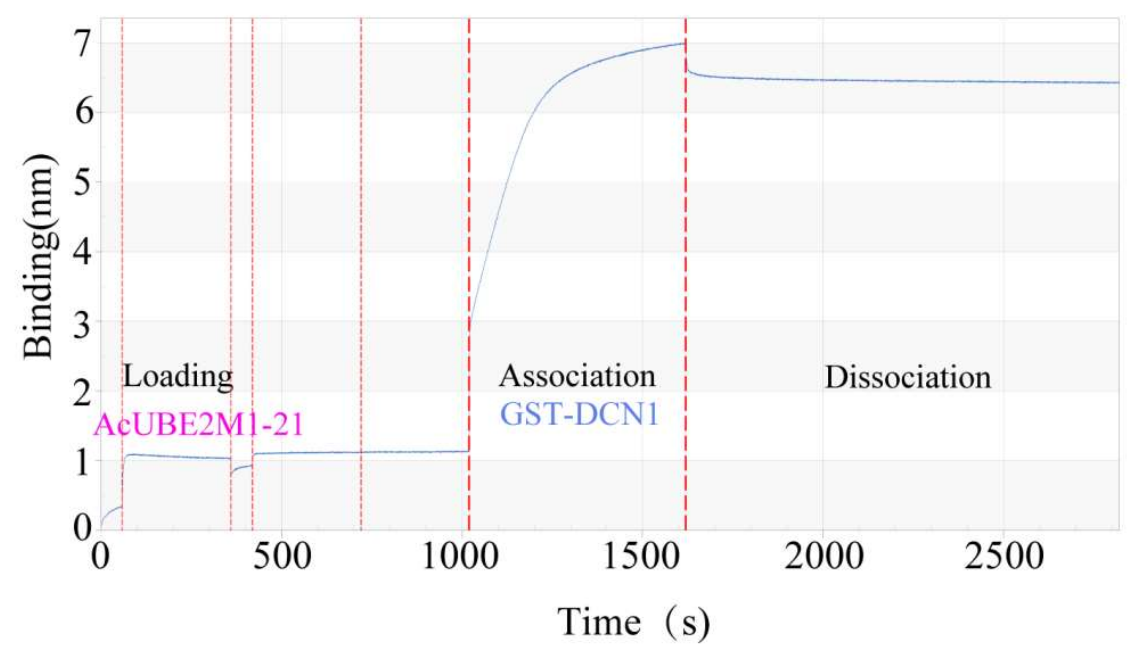

B

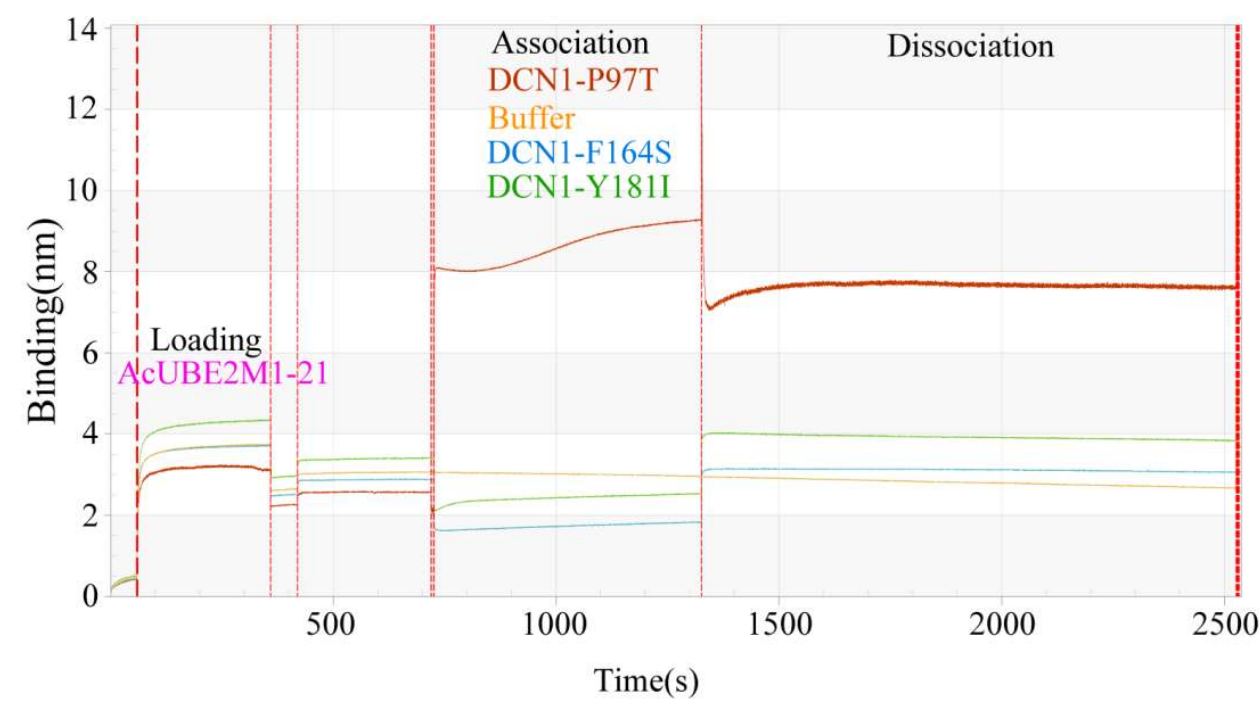

Figure S3. The direct interaction of Biotin-AcUBE2M ${ }^{1-21}$ peptides with wild type DCN1(GST-DCN1)(A) and its mutants(P97T, F164S and Y181I)(B). After loading Biotin-AcUBE2M ${ }^{1-21}$ peptides on Super Streptavidin (SSA) sensor, wild type DCN1(GST-DCN1)(A) and its mutants(P97T, F164S and Y181I) were added into the system, respectively. The signals were detected by Octet RED 96.

HPLC s pectra of representative compounds. 


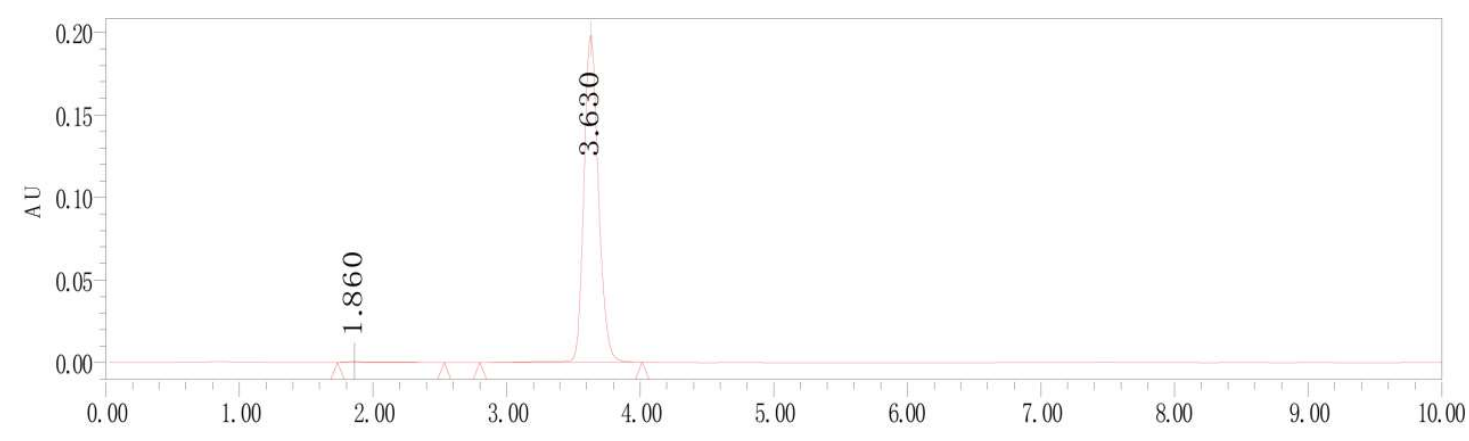

Minutes

\begin{tabular}{|c|c|c|c|}
\hline Peak & Retention Time & Area & \% Area \\
\hline 1 & 1.86 & 4826 & 0.32 \\
\hline 2 & 3.63 & 1489685 & 99.68 \\
\hline
\end{tabular}

HPLC chromatogram of compound DC-2N

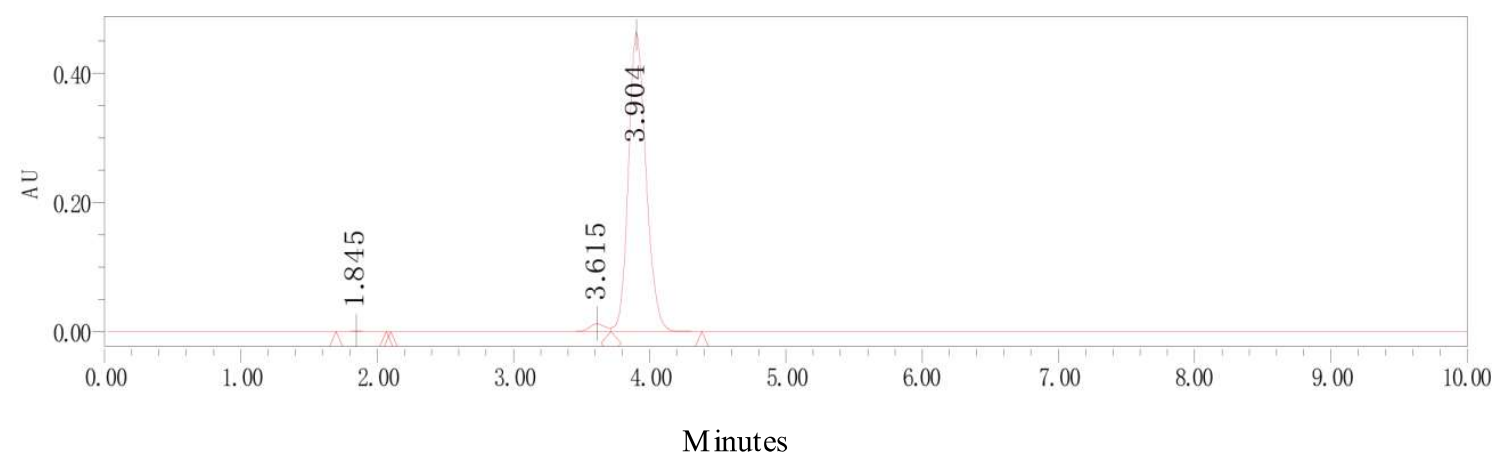

\begin{tabular}{|c|c|c|c|}
\hline Peak & Retention Time & Area & \% Area \\
\hline 1 & 1.85 & 2995 & 0.07 \\
\hline 2 & 3.62 & 103881 & 2.44 \\
\hline 3 & 3.90 & 4155191 & 97.49 \\
\hline
\end{tabular}

HPLC chromatogram of compound 39 


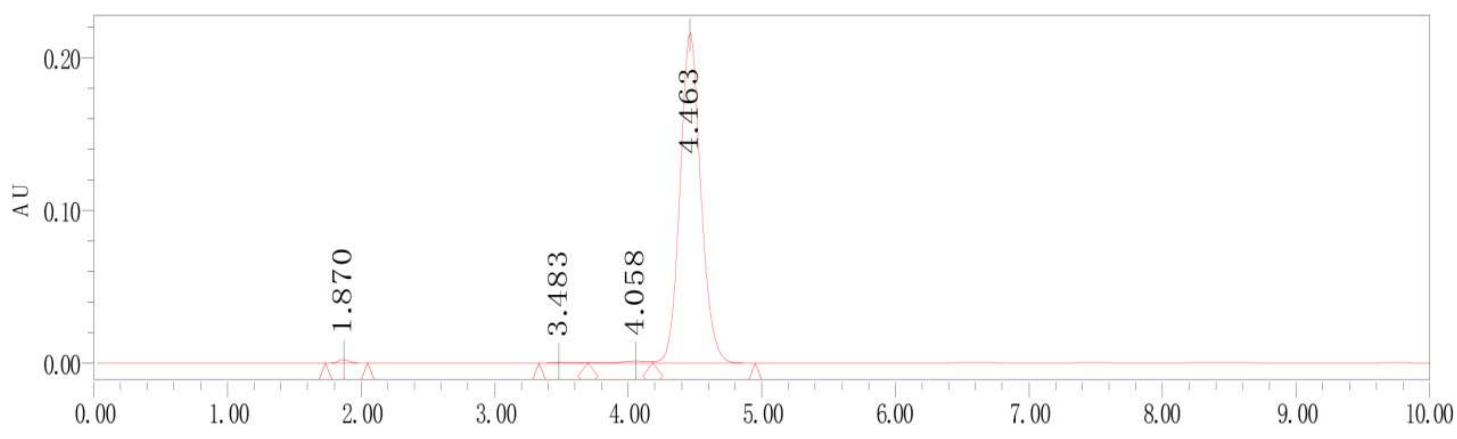

Minutes

\begin{tabular}{|c|c|c|c|}
\hline Peak & Retention Time & Area & \% Area \\
\hline 1 & 1.87 & 12311 & 0.52 \\
\hline 2 & 3.48 & 4238 & 0.18 \\
\hline 3 & 4.06 & 19441 & 0.82 \\
\hline 4 & 4.46 & 2348664 & 98.49 \\
\hline
\end{tabular}

HPLC chromatogram of compound DC-2 